\title{
Zambia: Fifth Review Under the Three-Year Arrangement Under the Extended Credit Facility, Requests for Waiver of Nonobservance of Performance Criterion and Modification of Performance Criteria, and Financing Assurances Review
}

The following documents have been released and are included in this package:

- The staff report for the Fifth Review Under the Three-Year Arrangement Under the Extended Credit Facility, Requests for Waiver of Nonobservance of Performance Criterion and Modification of Performance Criteria, and Financing Assurances Review, prepared by a staff team of the IMF, following discussions that ended on November 3, 2010, with the officials of Zambia on economic developments and policies. Based on information available at the time of these discussions, the staff report was completed on November 24, 2010. The views expressed in the staff report are those of the staff team and do not necessarily reflect the views of the Executive Board of the IMF.

- $\quad$ Supplement to the staff report

- A press release

- $\quad$ A statement by the Executive Director for Zambia

The document(s) listed below will be separately released

- $\quad$ Letter of Intent sent to the IMF by the authorities of Zambia*

- Memorandum of Economic and Financial Policies*

- $\quad$ Technical Memorandum of Understanding*

* Also included in the staff report

The policy of publication of staff reports and other documents allows for the deletion of marketsensitive information.

Copies of this report are available to the public from

International Monetary Fund $\bullet$ Publication Services

$70019^{\text {th }}$ Street, N.W. $\bullet$ Washington, D.C. 20431

Telephone: (202) 623-7430 • Telefax: (202) 623-7201

E-mail: publications@imf.org Internet: http://www.imf.org 
INTERNATIONAL MONETARY FUND

ZAMBIA

Fifth Review Under the Three-Year Arrangement Under the Extended Credit Facility, Requests for Waiver of Nonobservance of Performance Criterion and Modification of Performance Criteria, and Financing Assurances Review

\author{
Prepared by the African Department \\ (In consultation with other departments) \\ Approved by Michael Atingi-Ego and James Roaf
}

November 24, 2010

Discussions: September 2-15, 2010, and October 28-November 3, 2010, in Lusaka. The staff team consisted of George Tsibouris (head), Nils Maehle, Alfredo Baldini, Perry Perone (Resident Representative) (all AFR), Joong Beom Shin (FAD), and Kazuko Shirono (SPR). The mission met with the Minister of Finance and National Planning, Dr. Musokotwane; the Governor of the Bank of Zambia, Dr. Fundanga; other senior officials; and representatives of the business community, civil society, and Zambia's development partners.

IMF relations: Zambia joined the Fund on September 23, 1965, and has accepted the obligations of Article VIII, Sections 2, 3, and 4. The fourth review under the Extended Credit Facility (ECF) arrangement was concluded in June 2010. Zambia's current three-year ECF arrangement was approved in June 2008.

Exchange rate regime: Zambia maintains a floating exchange rate regime.

In the attached letter of intent (LoI) and Memorandum of Economic and Financial Policies (MEFP), the authorities review program implementation and outline their policies for the remainder of 2010 and for 2011. 


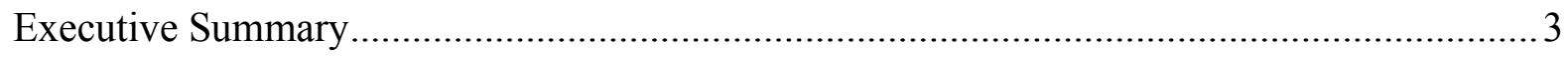

I. Background and Program Performance …………..................................................... 4

A. Strong Growth and Moderating Inflation ......................................................... 4

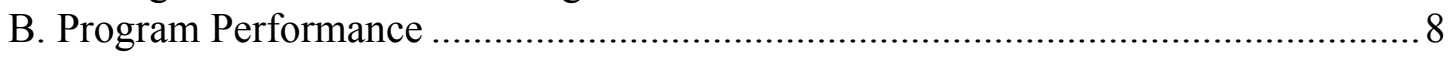

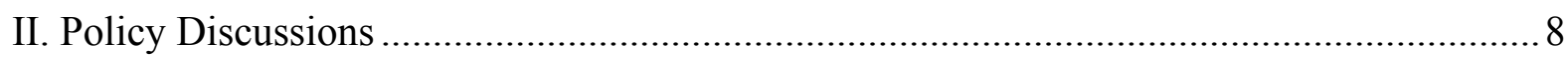

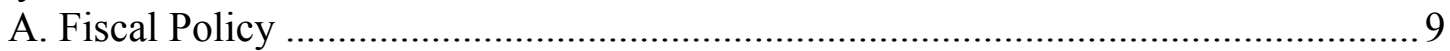

B. Monetary Policy ........................................................................................

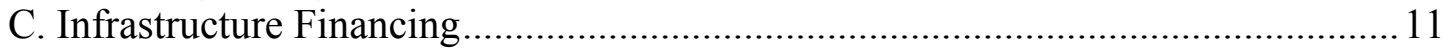

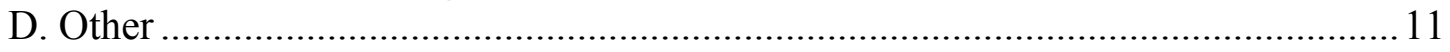

III. Program Monitoring and Modification of Performance Criteria ..................................... 12

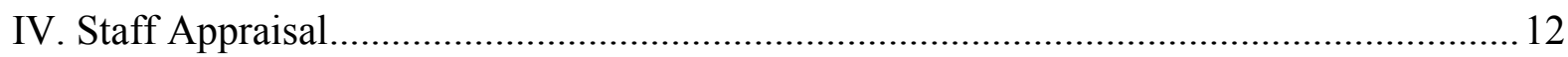

Tables

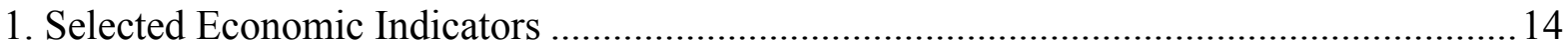

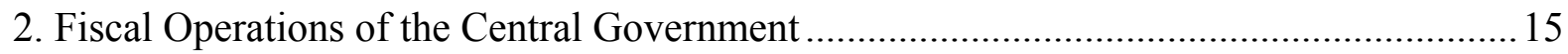

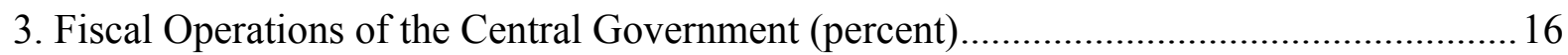

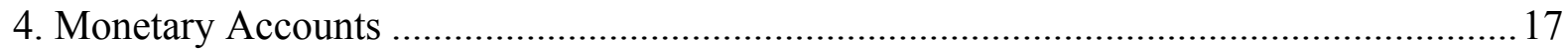

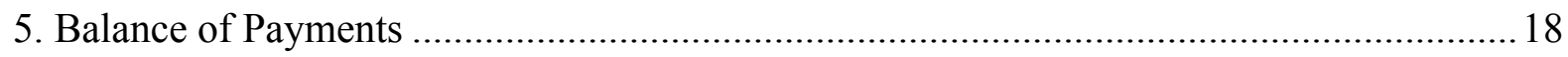

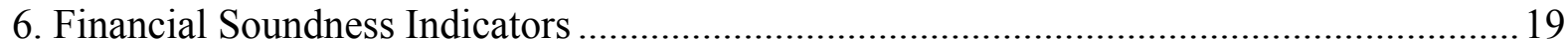

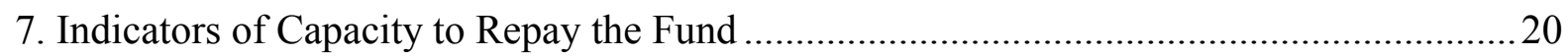

8. Schedule of Disbursements under the ECF Arrangement ................................................21

Figures

1. Balance of Payments Developments, 2005-10 ………................................................. 5

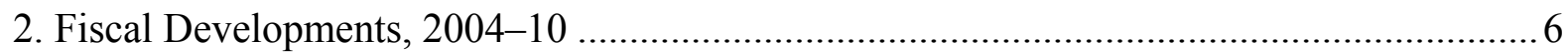

3. Monetary Developments, January 2007-September 2010 …….......................................

Box

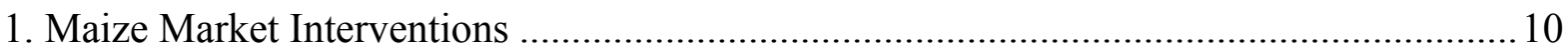

Appendixes

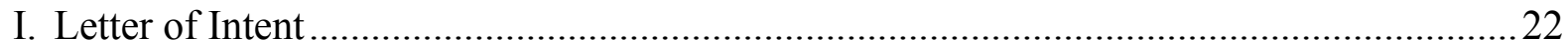

Attachment I. Memorandum of Economic and Financial Policies....................................22

Attachment II. Technical Memorandum of Understanding for the 2010-11, Extended

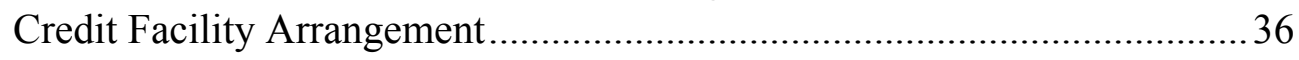

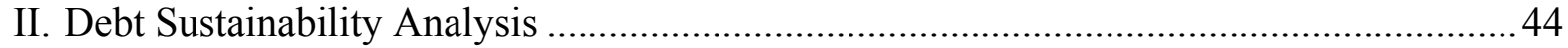

Annexes

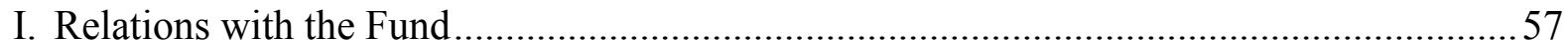

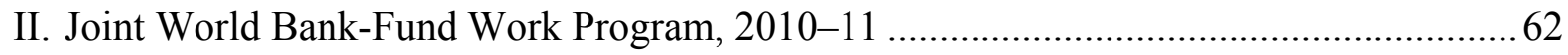

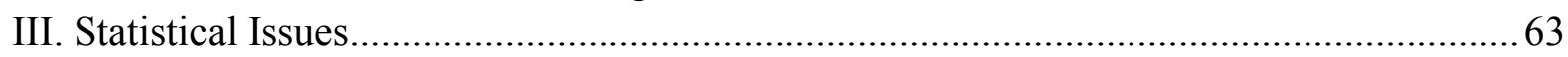




\section{EXECUTIVE SUMMARY}

\section{Zambia's strong economic performance continues under the Extended Credit Facility (ECF) and staff recommends completion of the fifth review.}

- $\quad$ All end-June 2010 quantitative performance criteria were met, and structural reforms are progressing.

- $\quad$ Strong growth and subdued inflation continue. GDP is projected to expand by 6.6 percent in 2010; inflation declined to 7.3 percent in October 2010; the current account deficit has narrowed; and international reserves are solid.

- $\quad$ The execution of the 2010 budget has been in line with the program, though the authorities needed financing for purchase of the record maize surplus. The overall fiscal deficit is projected to be around $3 / 4$ percent of GDP higher than envisaged.

- $\quad$ The economic outlook is positive. Copper prices have strengthened further, and credit to the private sector is picking up.

With a broadly unchanged macroeconomic outlook, the medium-term policy stance remains appropriate.

- $\quad$ The 2011 budget is consistent with the authorities' medium-term fiscal strategy to create space for priority spending to reduce poverty and enhance economic diversification to reduce Zambia's dependence on copper exports. The envisaged revenue enhancement is appropriately ambitious, and the expenditure mix shifts toward social and capital spending.

- Infrastructure financing needs are intensifying. The authorities plan to rely increasingly on nonconcessional financing of growth-critical infrastructure investments. In that context, they are strengthening their debt management and project appraisal capacity.

- $\quad$ The authorities are undertaking a reassessment of their maize pricing and marketing policies to limit budgetary exposure.

- $\quad$ Monetary policy appropriately targets a further reduction in underlying inflation. 


\section{Background ANd Program Performance}

\section{A. Strong Growth and Moderating Inflation}

1. Economic conditions are favorable, with robust growth and moderating inflation. Real output is projected to expand by 6.6 percent in 2010, (almost 1 percentage point higher than projected at the time of the fourth review), based on a significant increase in agricultural and mining output. Inflation declined to 7.3 percent in October 2010, mainly owing to the favorable maize crop, but underlying inflationary pressures related to nonfood remain. Buoyed by copper exports, the current account deficit is now projected to narrow in 2010 to just under 2 percent of GDP by year-end. International reserves remain relatively strong at about $3 \frac{1}{2} 2$ months of prospective imports as of end-October 2010.

\section{Broad money growth is rebounding and} credit to the private sector is slowly picking up. Lending rates are gradually declining. However, nonperforming loans remain high. The Bank of Zambia (BoZ) has intensified monitoring of one bank that has had difficulty meeting prudential requirements. Nonetheless, most banks remain well capitalized and have ample liquidity. Overall, banking profitability is edging upward, while average return on assets and return on equity are reverting to pre-crisis

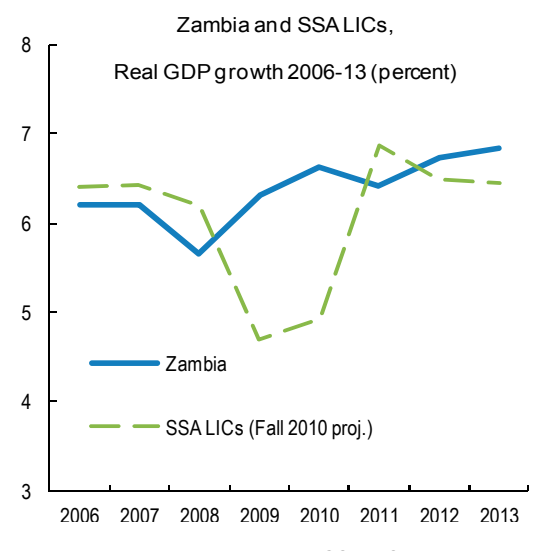
levels.
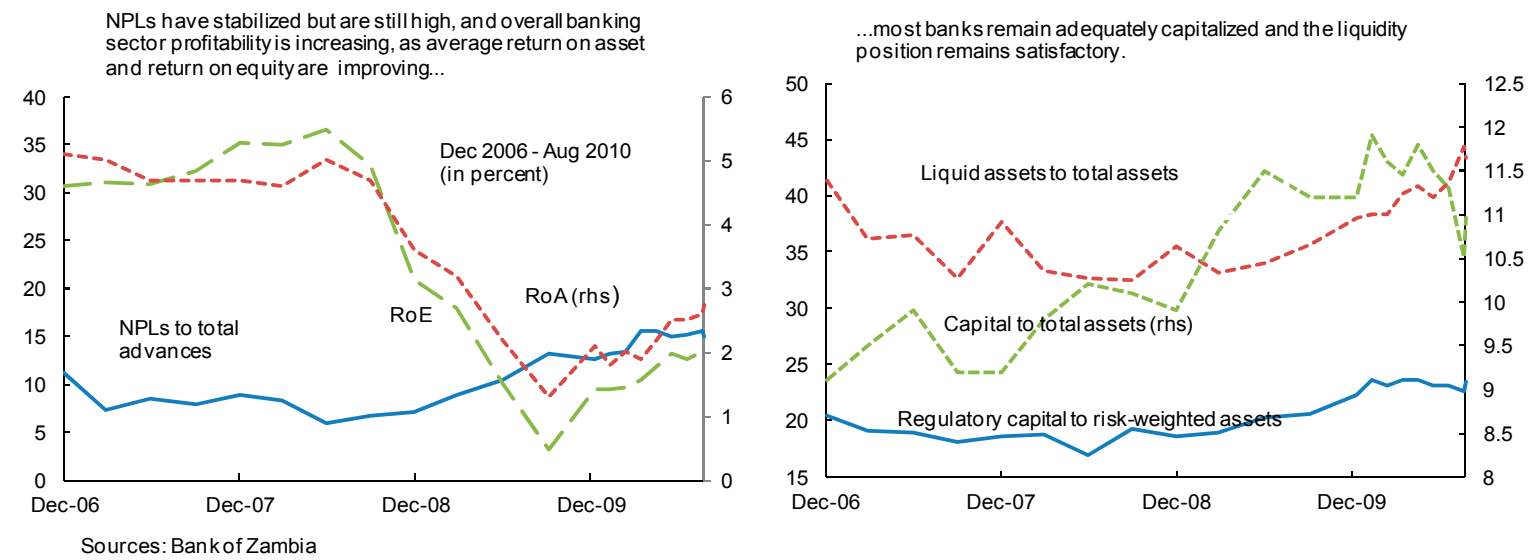

3. The execution of the $\mathbf{2 0 1 0}$ budget has been broadly in line with the program, though the authorities needed financing for purchase of the record maize surplus. The overall fiscal deficit (including grants) is now projected at around $3 \frac{1}{4}$ percent of GDP, compared to the programmed $2 \frac{1}{2}$ percent, with the government's transfers to the Food and Reserve Agency for the purchase of maize amounting to $1 \frac{1}{2}$ percent of GDP. 
Figure 1. Zambia: Balance of Payments Developments 2005Q1 - 2010Q3

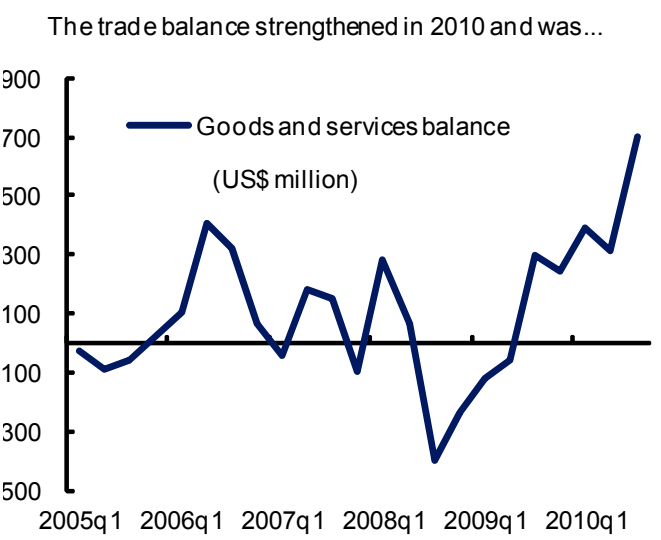

2005q1 2006q1 2007q1 2008q1 2009q1 2010q1

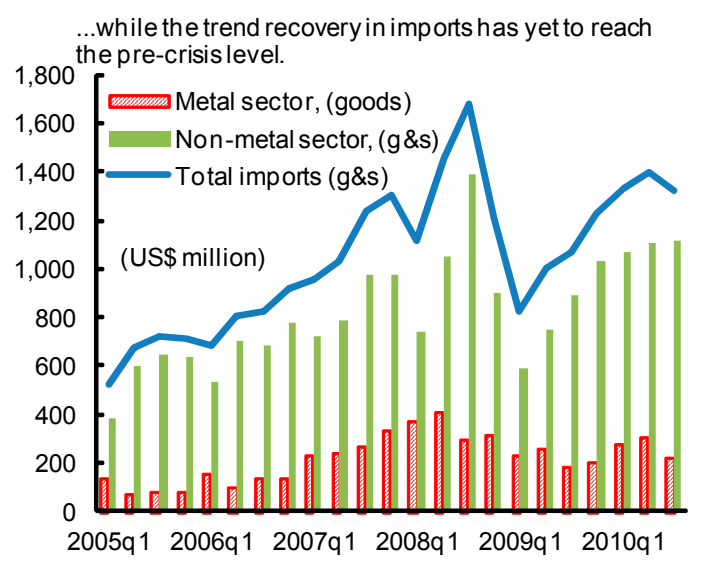

The real effective exchange rate has stabilized despite

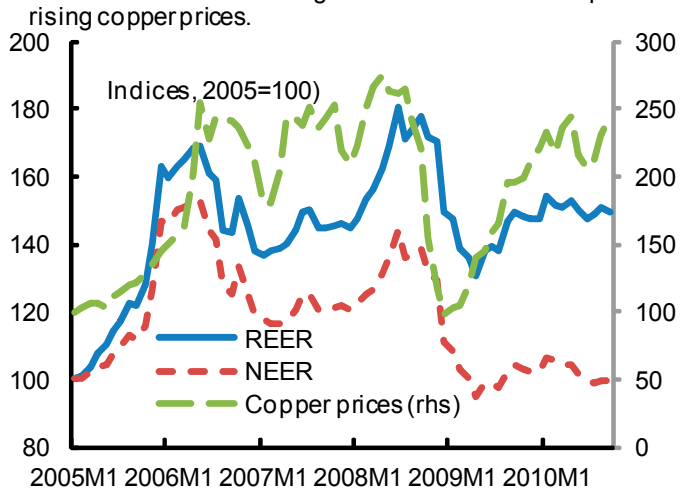

Sources: Zambian authorities and Fund staff estimates. ...larg ely driven by metal exports and highcopper prices...

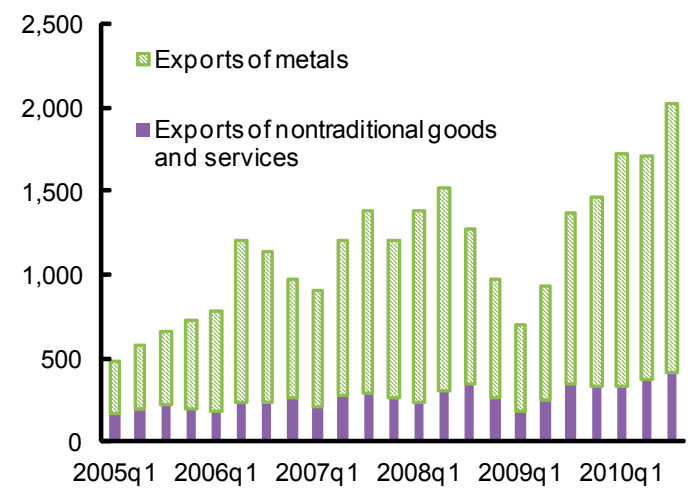

Dividend outflows are expected to remain large as copper prices continue to be high.

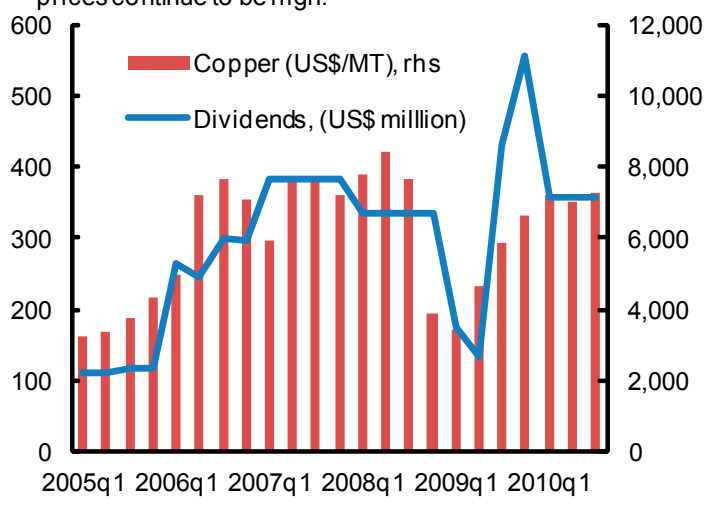

Reserves remain at their highest levels in years.

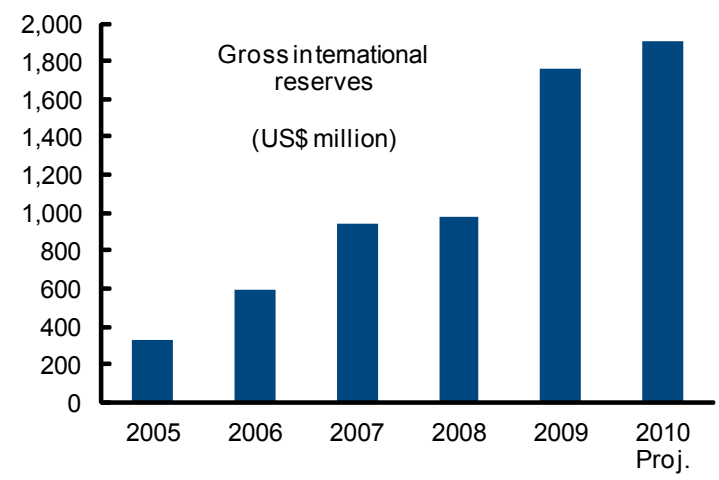


Figure 2. Zambia: Fiscal Developments, 2004-2010 (Percent of GDP)

The overall fiscal deficit in 2010 is projected to be higher because of the costs of purchasing the surplus maize.

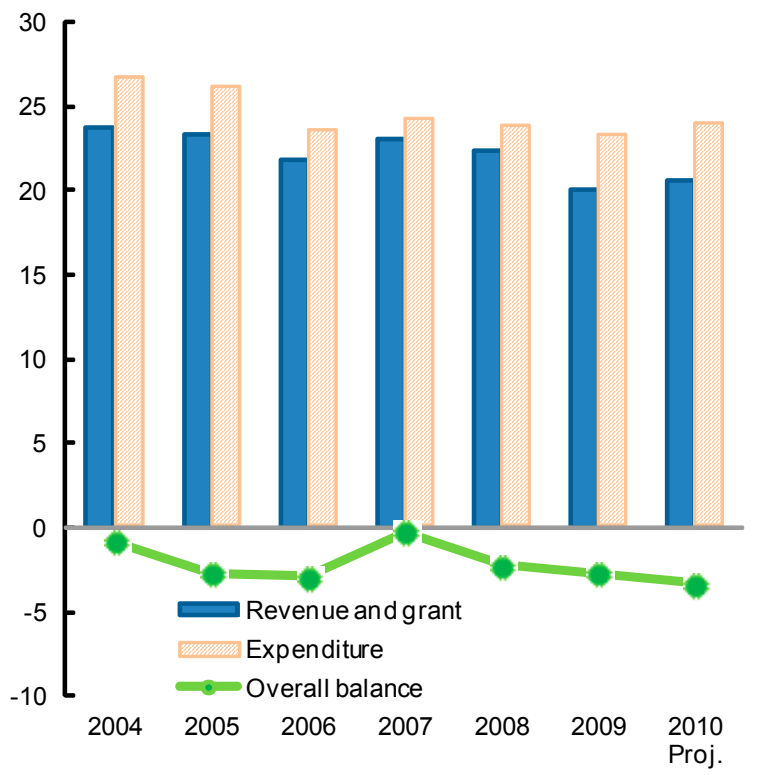

The higher deficit will be covered by ad ditional domestic borrowing.

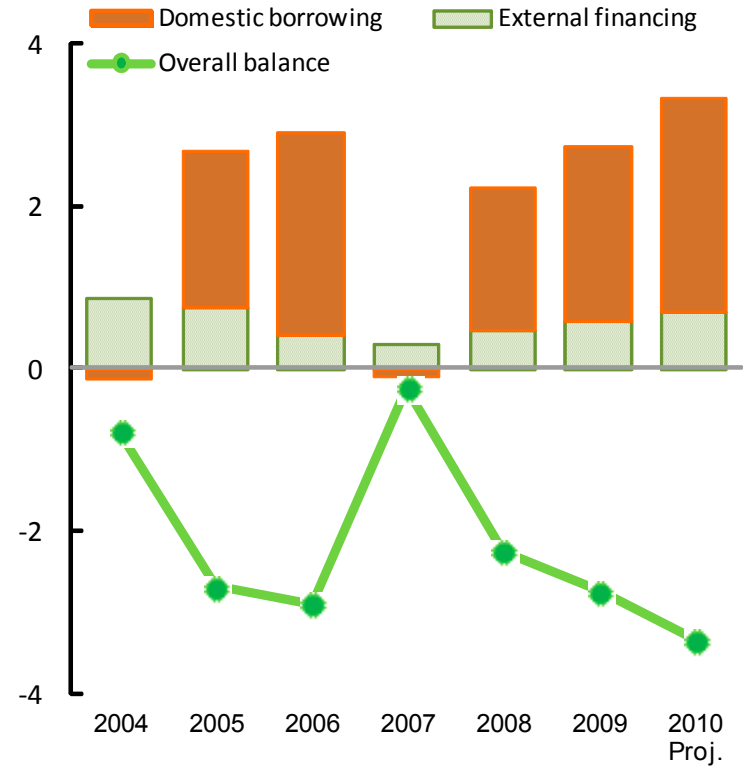

Revenues are recovering, helped by the payment of tax arrears from the mining sector, and increased payrolland import taxes.

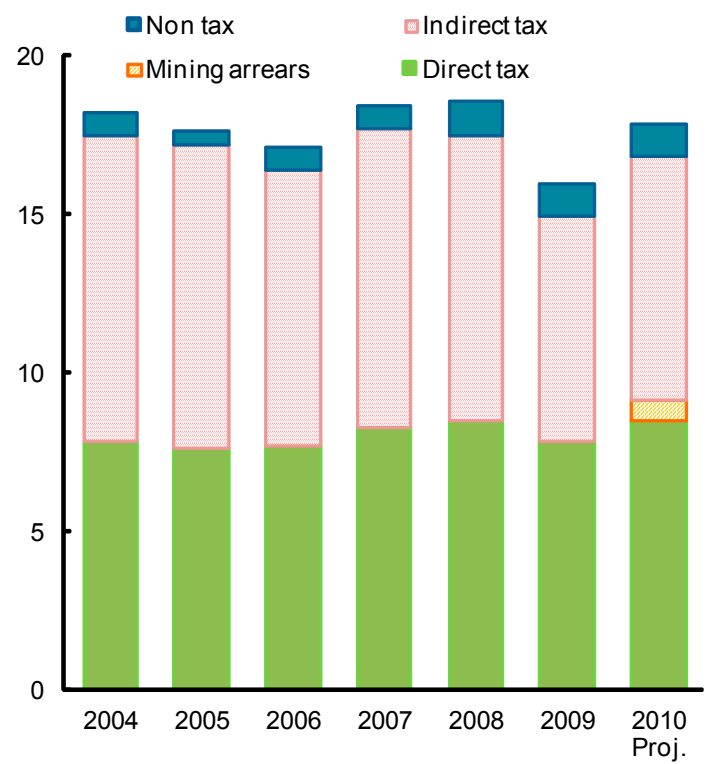

Current expenditures are being contained to provide space for much needed capital spending.

$\square$ Capital spending

■Other current spending (excluding maize costs)

Wages and salaries

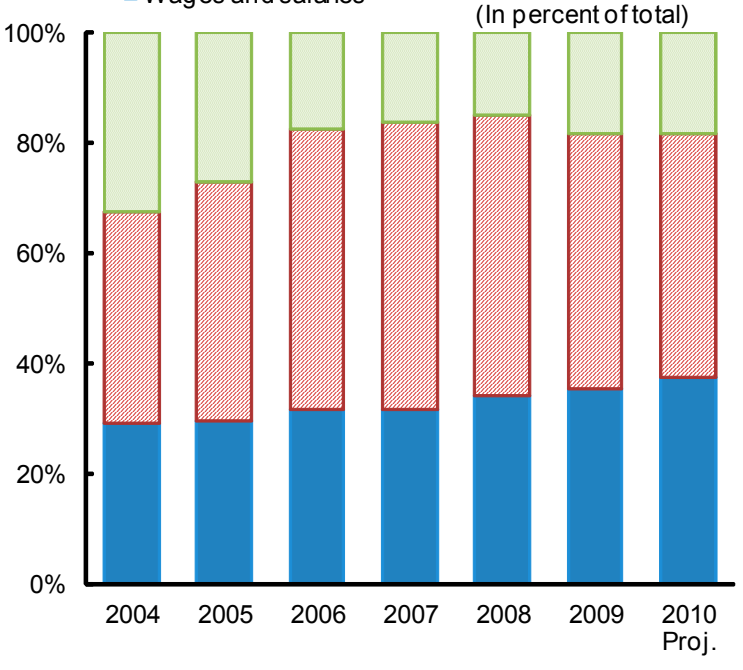

Sources: Zambian authorities and Fund staff estimates. 
Figure 3. Zambia: Monetary and Credit Developments, January 2007- September 2010
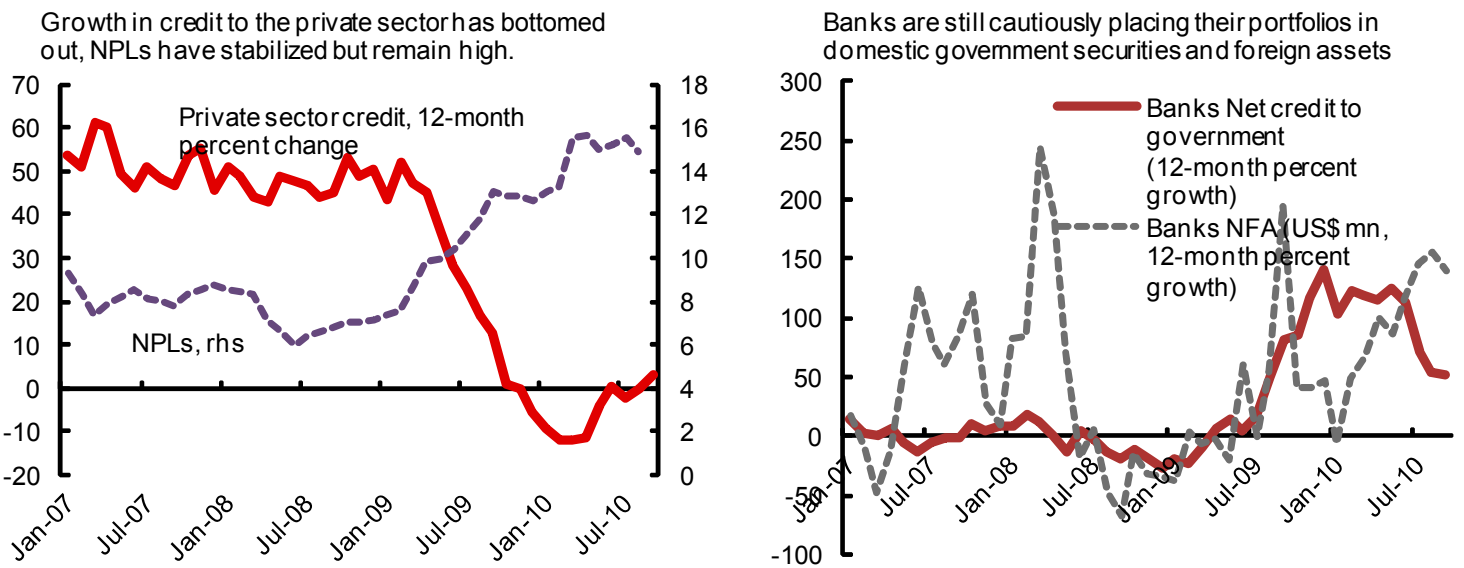

The challenge for the monetary authorities has been to keep reserve money onto a path consistent with a single-digit inflation target, given a larger-than-expected 40 rebound in broad money.

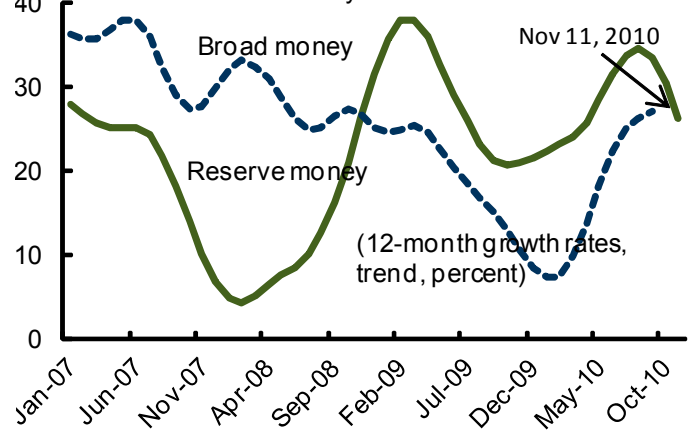
crisis level, while the temporary increase in velocity has been reversed.

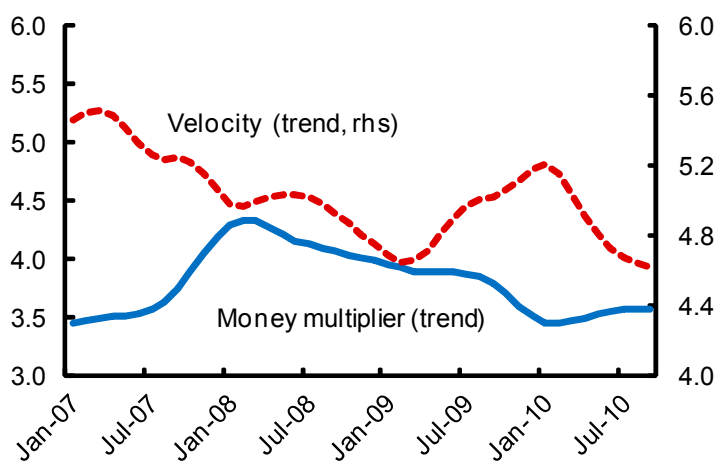

The Kwacha yield curve continues to tilt upward toward s positivereal levels..

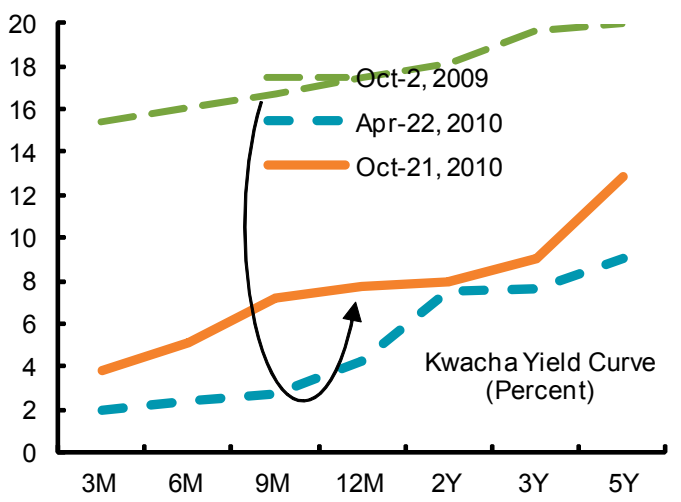

...while moderating inflation is helping reduce ban ks lend ing rates, while deposit rates remain flat and well below real positive levels.

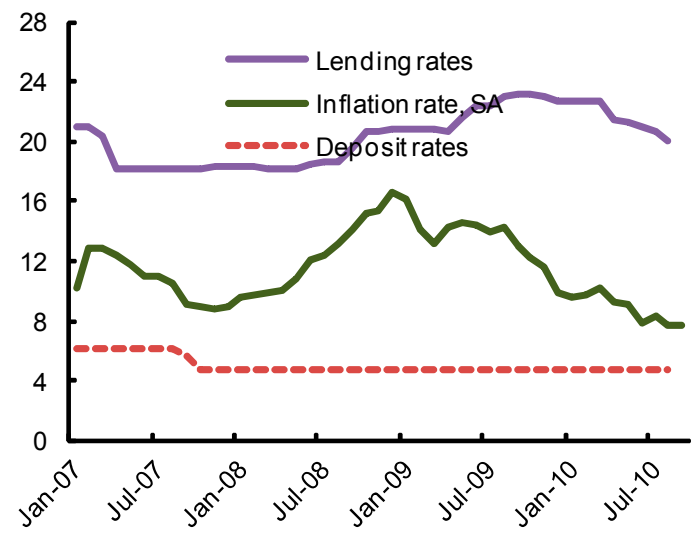

Sources: Bank of Zambia and Fund staff estimates. 


\section{B. Program Performance}

4. All performance criteria for end-June 2010 were met. ${ }^{1}$ Two of the three structural benchmarks for end-June and end-September 2010 were also met, albeit one with a modest delay - the Energy Regulation Board approved the electricity tariff increase in July. The government has established a lender-of-last resort framework, but preparation of the draft legislation and procedures for the financial sector contingency plan are taking longer than anticipated. The authorities finalized the review of tax administration and policy (structural benchmark for end September 2010), drawing from recommendations of the recent Fiscal Affairs Department technical assistance mission. The payment of domestic arrears at endJune 2010 was less than the indicative program floor because the prerequisite investigation and verification process took longer than envisaged.

5. The authorities are fundamentally restructuring the relevant debt management office and strengthening the assessment, recording, and provision of timely external debt data, and related procedures. They have reiterated their commitment to consult with IMF staff prior to contracting any potentially new nonconcessional loans. The authorities request and staff supports the granting of a waiver for the nonobservance of the endDecember 2009 ceiling on nonconcessional borrowing.

\section{Policy Discussions}

6. With a broadly unchanged macroeconomic outlook, the medium-term policy stance remains appropriate. External demand for Zambian products is expected to remain strong, with more than half of its exports now going to Asia and the Middle East. Domestic demand should gradually recover as broad-based real economic activity intensifies and bank lending to the private sector continues to pick up after the sharp contraction in 2009. The main risks include possible adverse developments in world copper and aid inflows. Fiscal policy discussions focused on incorporating the maize market intervention into the 2010 fiscal program and on creating fiscal space to boost

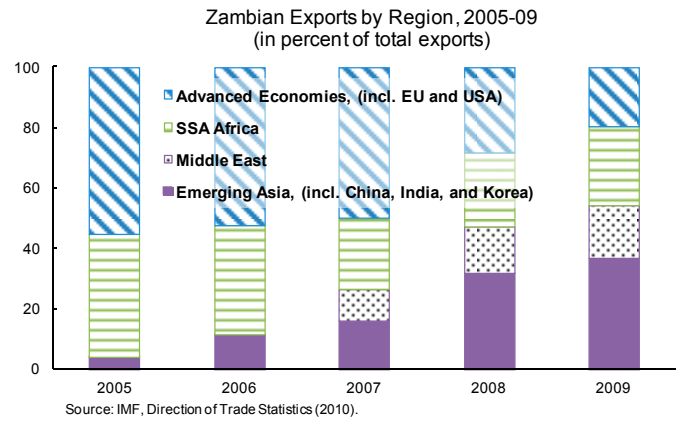
capital and social spending in the 2011 budget and onward. With pressing infrastructure needs, the authorities plan further nonconcessional borrowing to finance infrastructure, consistent with debt sustainability, and premised on effective debt management and project appraisal.

\footnotetext{
${ }^{1}$ See Tables 1 and 3 of the attached Memorandum of Economic and Financial Policies.
} 


\section{A. Fiscal Policy}

\section{Budgetary pressures for the end of $\mathbf{2 0 1 0}$ have intensified because of the} government's intermediary marketing role for the maize crop, which has far exceeded expectations this year (see Box 1 and MEFP 96). The 2009/10 maize crop hit a historical high of 2.8 million metric tons, more than double the average for the past decade. The Food Reserve Agency (FRA), supported by moderate budgetary resources, has traditionally purchased surplus maize from smallholder farmers at preannounced prices, to on-sell during the lean period and maintain a strategic

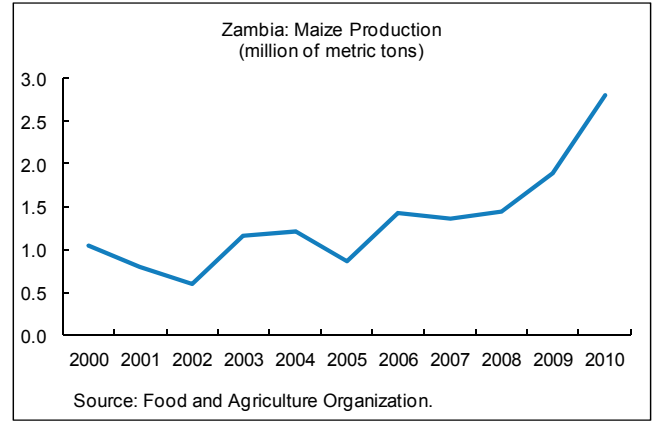
reserve. This year's record surplus crop has far exceeded FRA's capacity to finance such purchases (about 1.7 percent of GDP) on a

\begin{tabular}{lrrr}
$\begin{array}{l}\text { Zambia: Fiscal Operations of the Central Government } \\
\text { (Percent of GDP) }\end{array}$ \\
\hline & $\begin{array}{c}\text { Average } \\
2003-09\end{array}$ & $\begin{array}{l}\text { Prog. } \\
\text { Proj. }\end{array}$ \\
\hline Revenue & 18.0 & 17.8 & 18.4 \\
Expenditures & 25.8 & 23.9 & 23.4 \\
Current expenditures & 18.7 & 19.4 & 16.7 \\
Capital expenditure & 6.5 & 4.2 & 6.3 \\
$\quad$ Domestically financed & 2.1 & 3.0 & 3.7 \\
Foreign financed & 4.4 & 1.2 & 2.6 \\
Overall balance (cash basis) & -1.7 & -3.3 & -3.2 \\
Financing & 1.7 & 3.3 & 3.2 \\
External financing (net) & 0.7 & 0.7 & 1.8 \\
Domestic financing (net) & 1.0 & 2.6 & 1.4 \\
Memorandum items: & & & \\
Mining taxes & 0.6 & 2.2 & 2.2 \\
External budget support & 1.4 & 1.7 & 0.9 \\
\hline
\end{tabular}

Sources: Zambian authorities; and IMF staff estimates and projections.

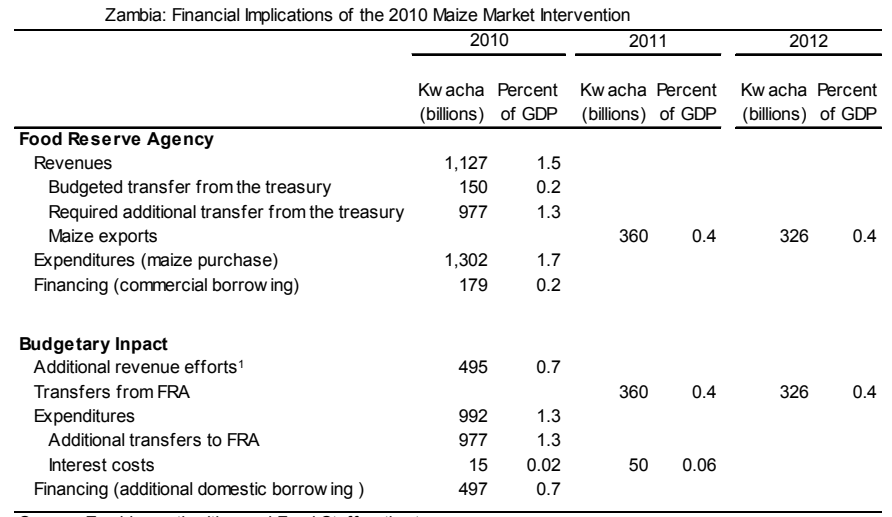

Source: Zambian authorities and Fund Staff estimates.

1 One-off payment of accrued tax arrears from the mining sector, previously unbudgeted.

commercial basis, and the government has stepped in to finance the residual amount (about 1.5 percent of GDP). The authorities are assessing their maize marketing and pricing policy, drawing on the lessons from this year to prevent a recurrence next year (MEFP $q 24$; new structural benchmark for end-March 2011). Governance reforms, including in the health and road sectors, are underway (MEFPq28-30).

\section{The 2011 budget is consistent with the authorities' medium-term strategy of generating fiscal space and using it for infrastructure spending (MEFP q13). The} envisaged revenue enhancement is appropriately ambitious and stems from new tax policy measures, administrative improvements, and planned payments as part of normalizing tax relations with the mining companies. The expenditure mix shifts toward capital spending, ${ }^{2}$

\footnotetext{
${ }^{2}$ This will require increased spending on operations and maintenance after completion of these new capital projects.
} 
while holding the line on wages through tight limits on new hiring. With an expected reduction in external budget support, an increased proportion of infrastructure spending (particularly in energy and roads) will be financed nonconcessionally.

\section{Box 1. Role of Government in the Maize Market}

The government has played a central role in maize marketing in Zambia during most of the post-independence period. Maize trading was deregulated in the early 1990s, but state intervention and control have been increasingly reintroduced. The 2005 Food Reserve Act amendment instructs the Food Reserve Agency (FRA) to engage in maize marketing, determine prices; and export any excess supply.

- $\quad$ FRA sets a floor price based on production costs and on consultations with the stakeholders. The announced floor price is only mandatory for FRA, and private trades commonly occur at lower prices. The prevailing FRA floor of kwacha 64,000 per $50 \mathrm{~kg}$ bag was announced in May 2009 and retained for the 2010 season. Maize prices in the region have slumped and now stand at about kwacha 40,000 per $50 \mathrm{~kg}$ bag.

- $\quad$ FRA buys only from smallholder farmers and there are limits on the number of bags that can be purchased from each farmer. They base total purchase volume on food security needs, budget allocations, and the market situation.

- $\quad$ Exporting and importing maize requires a license, which is granted for one year at a time. Exports of some 100,000 metric tons and 1.1 million metric tons were permitted for the 2008/09 and 2009/10 marketing seasons.

\section{B. Monetary Policy}

\section{The authorities are committed to bringing down inflation to 8 percent by} end-2010 and to 7 percent by end-2011(MEFP $\$ 15)$. Staff and the authorities agreed that a moderate tightening of monetary policy was appropriate, particularly given the liquidity injection stemming from the recent maize purchase. This would help rein in broad money growth and give greater confidence in achieving the authorities' announced inflation target. In 2011, broad money is projected to expand by 15 percent, broadly in line with nominal GDP, and reserve money is targeted to grow by almost 12 percent. The envisaged monetary program would provide ample room for increased credit to the private sector. Commercial bank lending rates should continue to decline as inflation expectations are dampend and nonperforming loans are being brought under control. A lowering of bank operating costs is needed to reduce (real) lending rates further.

\section{Keeping the reform momentum in the financial system is critical to} strengthening its stability and increasing efficiency (MEFP q22, 23). The Bank of Zambia's priorities, as formulated in phase II of the Financial Sector Development Plan, are to improve access to financial services and enhance market infrastructure and the financial 
safety net (through the Financial Sector Contingency Plan and development of a Deposit Protection Scheme). Staff concurs with these priorities.

\section{Infrastructure Financing}

11. Infrastructure financing needs are becoming more acute, with large growth-critical electricity and transportation projects in the pipeline (MEFP 913,31 ). Electricity peak-load shortages and the thin and deteriorating road infrastructure are fundamental impediments to economic diversification and to a further strengthening of economic growth. Given challenges in identifying sufficient concessional resources, the government intends to continue contracting relatively modest amounts of loans on nonconcessional terms to finance electricity and road projects. These loans would not have a material impact on debt dynamics, with the risk of debt distress remaining low and well beneath critical thresholds (see the DSA supplement). The authorities request, and staff supports, a shift from nonconcessional borrowing tied to specific projects to a sector-based approach in the program, because this would provide more flexibility to align project sequencing to changing circumstances.

\section{Increased reliance on nonconcessional financing for infrastructure spending will go hand-in-hand with an enhancement of debt management and project appraisal} capacity (MEFP $\{32,33$ ). Debt management has suffered from insufficient focus. The authorities are determined to tackle this problem speedily through a reshuffling of staff and enhanced staff training. There will soon be a fundamental restructuring of the external debt recording and external debt management units along functional lines, to create a Debt Management Office structured in line with international best practices. The authorities are also putting in place procedures to reconcile manual and electronic debt data records. Progress in strengthening the effectiveness of the Debt Management Office will be monitored by staff in the next program review. Investment projects are routinely subject to appraisals of viability, but the authorities realize that their project appraisal capacity could be strengthened. They intend to rely increasingly on private sector expertise while their expertise is bolstered through technical assistance. ${ }^{3}$ Staff supports the authorities' plans in these areas.

\section{Other}

\section{The authorities continue to make efforts to settle arrears to external private} creditors stemming from the past imposition of exchange controls. Settlement terms similar to those provided by the Paris Club were offered to commercial creditors with outstanding arrears. The authorities are continuing to verify outstanding claims to private

\footnotetext{
${ }^{3}$ A 2009 joint IMF-World Bank mission provided technical assistance on formulation of a debt management strategy and feedback on the authorities' existing debt management strategy.
} 
entities and individuals. The exchange restrictions evidenced by the accumulation of these external payments arrears are subject to Fund approval under Article VIII.

\section{Program Monitoring and Modification of Performance Criteria}

14. Program monitoring will continue on a semiannual basis. The authorities propose modification of two quantitative performance criteria (on net domestic assets and net domestic financing) for end-December 2010 (MEFP Table 1). Indicative targets have been set for 2011 (MEFP Table 2). The authorities also request replacement of the project-specific nonzero nonconcessional borrowing ceiling set at the time of the fourth ECF review with sector-specific ceilings for the roads and electricity. In the structural area, the sixth review will be based on an assessment of progress under the authorities' reform program, in particular public financial management, maize market policies, and financial sector reforms, to achieve the macroeconomic objectives described in Table 3 of the MEFP.

\section{StafF APPRAisal}

15. Economic performance continues to be strong. All end-June 2010 quantitative performance criteria were met, and structural reforms are progressing. Inflation is subdued; the current account deficit has narrowed; international reserves have remained solid; and the economic outlook is positive with continued strong growth. Zambia's risk of debt distress remains low.

16. Going forward, the key medium-term fiscal policy challenge remains to create space for priority spending to reduce poverty, enhance economic diversification, and reduce Zambia's dependence on copper exports. The 2011 budget is consistent with meeting these challenges. The envisaged revenue enhancement is appropriately ambitious, and the expenditure mix shifts toward social and capital spending. Further measures are needed, however, over the medium term to enhance revenue mobilization, contain current spending, and improve spending efficiency.

17. Infrastructure financing needs are becoming more acute. The planned increased reliance on nonconcessional financing of infrastructure needs is appropriate given the circumstances and the moderate external debt levels. The authorities should strictly direct nonconcessional financing to growth-critical spending that will provide the highest possible economic return. Strengthened debt management and project appraisal capacity is critical in this regard. Staff welcomes the authorities' determination to address these issues speedily.

\section{Monetary policy appropriately targets a further reduction in underlying} inflation. The agreed moderate tightening of monetary policy should help keep broad money growth in check and ensure that inflation continues to decline as targeted. Staff welcomes the Bank of Zambia's proactive approach in bank supervision and its commitment to continued financial sector development. Implementation of the second phase of the Financial Sector 
Development Plan should help enhance market infrastructure, increase access to financial services, and strengthen the financial safety net.

19. Staff welcomes the authorities' commitment to reassessing their maize pricing policies. The exceptionally large bumper maize harvest and its resulting significant impact on the budget highlight the need to reassess the government's maize policy. To prevent a recurrence in subsequent years, staff urges the authorities to establish a pricing and marketing system for maize that limits budgetary exposure, is reflective of market conditions, and gives a gradually larger role to the private sector in domestic and external trade in agriculture products, including maize.

\section{Staff recommends the completion of the fifth review under the ECF} arrangement and the financing assurances review. It supports the request for a waiver of the missed end-2009 ceiling on nonconcessional borrowing. The breach of the ceiling was so small as to be trivial with no material impact on debt sustainability, and the authorities are taking further measures to strengthen debt management. Staff also supports the authorities' request for modification of end-December 2010 performance criteria. The exogenous maize shock that the country experienced was large. The authorities intend to capitalize on lessons learned and remain committed to sound macroeconomic policies. 
Table 1. Zambia: Selected Economic Indicators

\begin{tabular}{|c|c|c|c|c|c|c|c|}
\hline & \multirow[t]{2}{*}{2009} & \multicolumn{2}{|c|}{2010} & \multicolumn{2}{|c|}{2011} & \multirow{2}{*}{$\begin{array}{l}2012 \\
\text { Proj. }\end{array}$} & \multirow{2}{*}{$\begin{array}{l}2013 \\
\text { Proj. }\end{array}$} \\
\hline & & $\begin{array}{r}\text { Prog. } \\
\text { CR 10/208 }\end{array}$ & Rev. Prog. & $\begin{array}{r}\text { Proj. } \\
\text { CR 10/208 }\end{array}$ & Rev. Proj. & & \\
\hline & \multicolumn{7}{|c|}{ (Percent changes; unless otherwise indicated) } \\
\hline \multicolumn{8}{|l|}{ National account and prices } \\
\hline GDP growth at constant prices & 6.3 & 5.8 & 6.6 & 6.0 & 6.4 & 6.7 & 6.8 \\
\hline GDP deflator & 10.4 & 9.8 & 10.3 & 8.3 & 7.6 & 5.5 & 4.6 \\
\hline GDP at market prices (Billions of kwacha) & 64,616 & 76,385 & 76,015 & 87,756 & 87,014 & 98,012 & 109,488 \\
\hline \multicolumn{8}{|l|}{ Consumer prices } \\
\hline Consumer prices (average) & 13.4 & 8.2 & 8.6 & 7.5 & 8.8 & 6.5 & 5.5 \\
\hline Consumer prices (end of period) & 9.9 & 8.0 & 8.0 & 7.0 & 7.0 & 6.0 & 5.0 \\
\hline \multicolumn{8}{|l|}{ External sector } \\
\hline Terms of trade (deterioration -) & -14.6 & 14.1 & 30.1 & 4.9 & -3.1 & -7.4 & -8.1 \\
\hline Average exchange rate (kwacha per U.S. dollar) & 5,046 & $\ldots$ & $\ldots$ & $\ldots$ & $\ldots$ & $\ldots$ & $\ldots$ \\
\hline (percentage change; depreciation -) & -34.7 & $\ldots$ & $\ldots$ & $\ldots$ & $\ldots$ & $\ldots$ & $\ldots$ \\
\hline Real effective exchange rate (depreciation -$)^{1}$ & -14.7 & $\cdots$ & $\cdots$ & $\cdots$ & $\cdots$ & $\cdots$ & $\cdots$ \\
\hline \multicolumn{8}{|l|}{ Money and credit (end of period, unless otherwise specified) ${ }^{2}$} \\
\hline Domestic credit to the private sector & -5.7 & 15.5 & 14.0 & 15.5 & 18.3 & $\ldots$ & $\ldots$ \\
\hline Reserve money (end of month) & 19.3 & 9.7 & 8.0 & 13.7 & 11.7 & $\ldots$ & $\ldots$ \\
\hline Broad Money (M3) & 7.7 & 16.0 & 23.5 & 18.0 & 15.0 & $\cdots$ & $\cdots$ \\
\hline & \multicolumn{7}{|c|}{ (Percent of GDP; unless otherwise indicated) } \\
\hline \multicolumn{8}{|l|}{ National accounts } \\
\hline Gross investment & 22.1 & 22.5 & 22.5 & 22.8 & 22.8 & 24.2 & 22.2 \\
\hline Government & 4.3 & 4.7 & 4.2 & 4.7 & 6.3 & 8.7 & 8.6 \\
\hline Private & 17.8 & 17.8 & 18.3 & 18.1 & 16.5 & 15.5 & 13.6 \\
\hline National savings & 16.5 & 20.4 & 21.8 & 20.0 & 20.2 & 19.2 & 17.0 \\
\hline Gross foreign savings & 5.6 & 2.1 & 0.7 & 2.8 & 2.6 & 5.0 & 5.2 \\
\hline \multicolumn{8}{|l|}{ Central government budget } \\
\hline Revenue & 18.6 & 16.3 & 17.8 & 17.1 & 18.4 & 18.5 & 18.7 \\
\hline Tax & 17.5 & 15.4 & 16.8 & 16.6 & 17.6 & 17.7 & 17.9 \\
\hline Nontax & 1.0 & 0.9 & 1.0 & 0.5 & 0.8 & 0.8 & 0.8 \\
\hline Grants & 3.8 & 3.4 & 2.8 & 2.6 & 1.8 & 2.4 & 2.2 \\
\hline Total expenditure & 23.8 & 22.3 & 23.9 & 21.4 & 23.4 & 24.9 & 24.1 \\
\hline Current expenditures & 19.1 & 17.3 & 19.4 & 16.6 & 16.7 & 16.0 & 15.4 \\
\hline Capital expenditure & 3.6 & 4.7 & 4.2 & 4.7 & 6.3 & 8.7 & 8.6 \\
\hline Domestic arrears payments & 1.1 & 0.4 & 0.4 & 0.1 & 0.4 & 0.2 & 0.2 \\
\hline Overall balance ${ }^{3}$ & -1.5 & -2.5 & -3.3 & -1.7 & -3.2 & -4.0 & -3.2 \\
\hline Excluding grants & -5.2 & -5.9 & -6.1 & -4.3 & -5.0 & -6.4 & -5.4 \\
\hline Financing & 2.2 & 2.5 & 3.3 & 1.7 & 3.2 & 4.0 & 3.2 \\
\hline External financing (net) & 0.5 & 0.6 & 0.7 & 0.5 & 1.8 & 3.1 & 2.4 \\
\hline Domestic (net) & 1.8 & 1.9 & 2.6 & 1.2 & 1.4 & 0.9 & 0.8 \\
\hline \multicolumn{8}{|l|}{ External sector } \\
\hline Current account balance & -3.2 & -3.5 & -1.6 & -3.9 & -3.5 & -6.3 & -6.3 \\
\hline (excluding grants) & -9.3 & -5.2 & -3.2 & -5.4 & -4.5 & -7.4 & -7.3 \\
\hline Gross international reserves (months of prospective imports) ${ }^{4}$ & 3.7 & 3.7 & 3.4 & 3.9 & 3.6 & 3.7 & 3.6 \\
\hline \multicolumn{8}{|l|}{ Public debt } \\
\hline Total central government debt (end-period) & 26.0 & 26.4 & 25.7 & 26.8 & 26.7 & 28.3 & 29.1 \\
\hline External & 11.3 & 13.4 & 10.6 & 14.5 & 12.1 & 14.5 & 15.9 \\
\hline Domestic (excludes domestic arrears) & 14.7 & 13.0 & 15.1 & 12.4 & 14.6 & 13.9 & 13.3 \\
\hline
\end{tabular}

Sources: Zambian authorities; and IMF staff estimates and projections.

${ }^{1}$ Excludes Zimbabwe.

${ }^{2}$ 2010-11 revised program projections are based on a standardized report form (SRF) which accords with the concepts and definitions of the Monetary and Financial Statistics Manual (MFSM). 2008-2009 data are based on pre-SRF monetary survey.

${ }^{3}$ Including discrepancy between the above-the-line balance and below-the-line financing.

${ }^{4}$ Includes the SDR allocation of SDR 401 million in 2009. 
Table 2. Zambia: Fiscal Operations of the Central Government (Billions of kwacha)

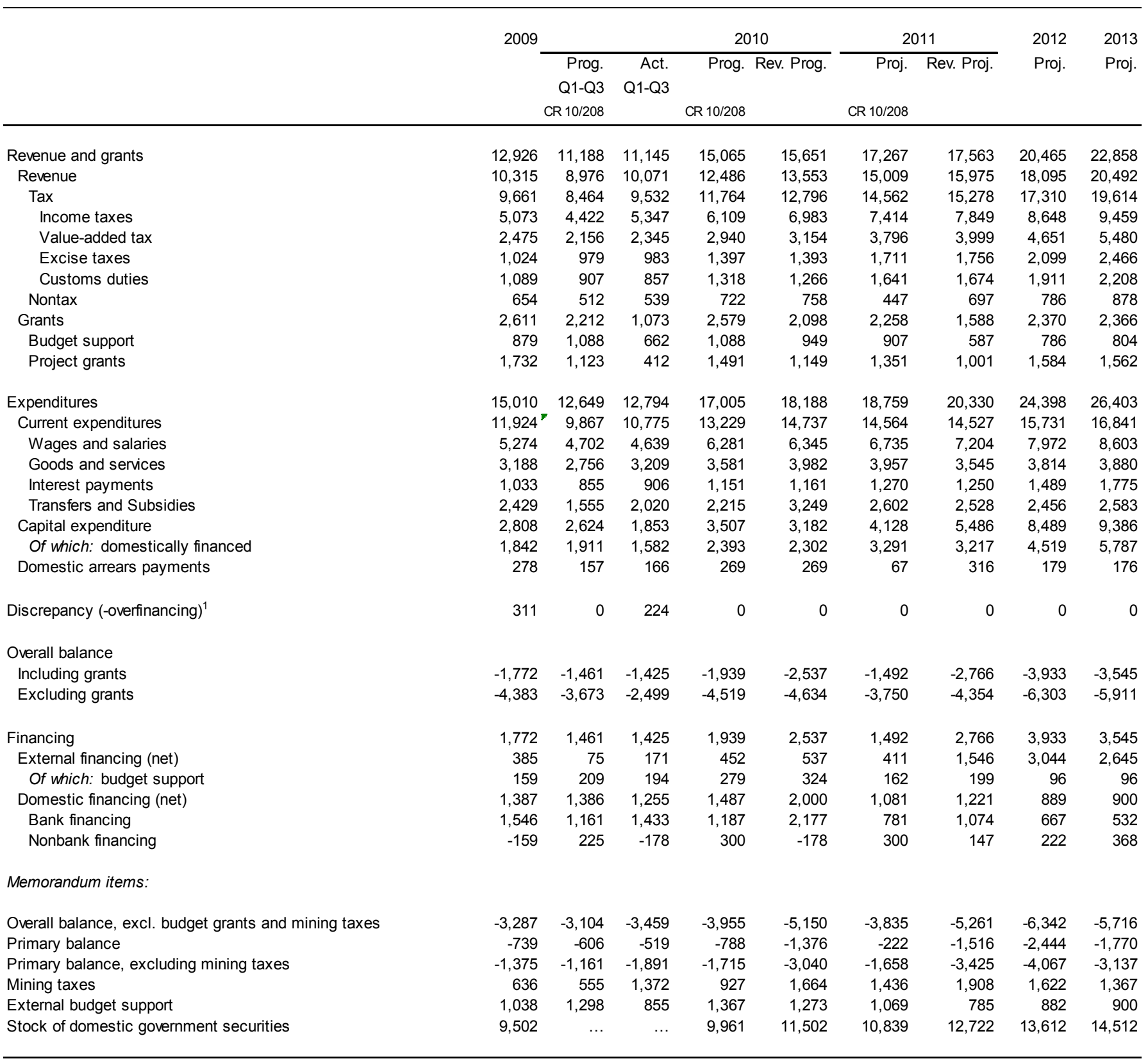

Sources: Zambian authorities; and IMF staff estimates and projections.

${ }^{1}$ Discrepancy largely reflects changes in the carryover of budgetary releases. 
Table 3. Zambia: Fiscal Operations of the Central Government

(Percent of GDP)

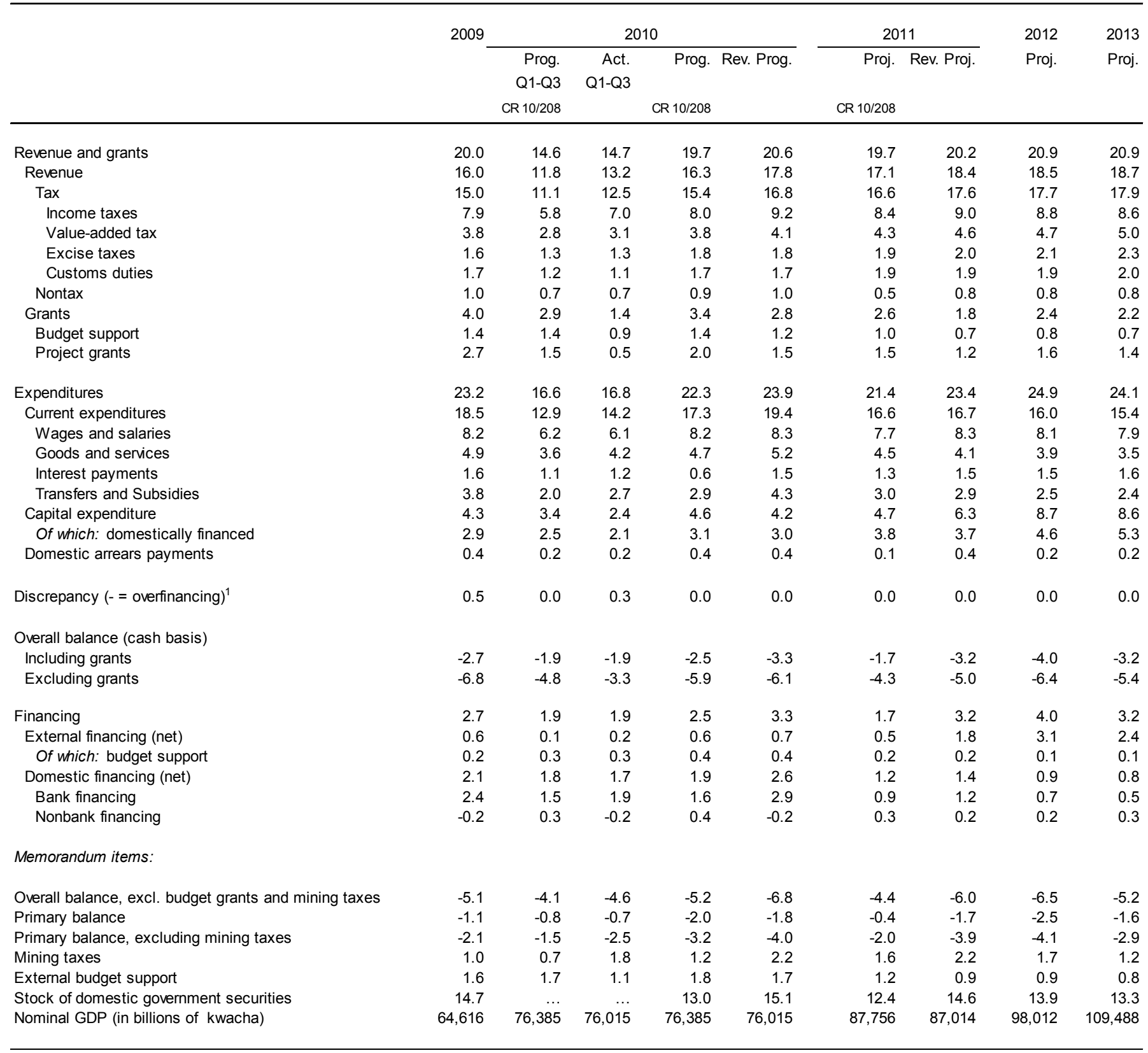

Sources: Zambian authorities; and IMF staff estimates and projections.

${ }^{1}$ Discrepancy largely reflects changes in the carryover of budgetary releases. 
Table 4. Zambia: Monetary Accounts ${ }^{1}$

(Billions of kwacha, unless otherwise indicated)

\begin{tabular}{|c|c|c|c|c|c|c|c|}
\hline & \multirow[t]{2}{*}{2009} & \multirow{2}{*}{$\begin{array}{l}\text { Sep. } \\
\text { Prog. } \\
\text { CR 10/208 }\end{array}$} & \multirow{2}{*}{$\begin{array}{l}\text { Sep. } \\
\text { Act. }\end{array}$} & \multicolumn{2}{|c|}{2010} & \multicolumn{2}{|c|}{2011} \\
\hline & & & & $\begin{array}{r}\text { Prog. } \\
\text { CR 10/208 }\end{array}$ & Rev. Prog. & $\begin{array}{r}\text { Proj. } \\
\text { CR 10/208 }\end{array}$ & Rev. Proj. \\
\hline \multicolumn{8}{|l|}{ Monetary Survey } \\
\hline Net foreign assets & 5,178 & 5,088 & 7,254 & 5,200 & 6,257 & 6,748 & 7,336 \\
\hline Net domestic assets & 8,619 & 10,519 & 10,091 & 10,804 & 10,775 & 12,137 & 12,246 \\
\hline Domestic Claims & 11,711 & 13,814 & 13,636 & 14,099 & 14,761 & 16,270 & 17,455 \\
\hline Net Claims on Central Government & 3,698 & 4,859 & 5,050 & 4,885 & 5,795 & 5,667 & 6,869 \\
\hline Claims on Other Sectors & 8,013 & $\ldots$ & 8,586 & 9,214 & 8,967 & 10,604 & 10,586 \\
\hline Claims on Other Financial Corporations & 58 & $\ldots$ & 50 & 58 & 50 & 58 & 50 \\
\hline Claims on State and Local Government & 5 & $\ldots$ & 5 & 5 & 5 & 5 & 5 \\
\hline Claims on Public Non-financial Corporations & 208 & $\ldots$ & 84 & 208 & 84 & 208 & 84 \\
\hline Claims on Private Sector & 7,741 & $\ldots$ & 8,447 & 8,943 & 8,828 & 10,332 & 10,447 \\
\hline Other Items net & $-3,092$ & $-3,295$ & $-3,545$ & $-3,295$ & $-3,986$ & $-4,133$ & $-5,209$ \\
\hline Broad Money (M3) & 13,797 & 15,607 & 17,345 & 16,004 & 17,032 & 18,885 & $19,582.1$ \\
\hline Quasi money (M2) & 8,818 & 9,975 & 11,256 & 10,229 & 11,127 & 12,070 & 12,734 \\
\hline Foreign exchange deposits & 4,979 & 5,632 & 6,089 & 5,775 & 5,905 & 6,815 & 6,848 \\
\hline \multicolumn{8}{|l|}{ Monetary Authorities } \\
\hline Net foreign assets & 3,996 & 4,227 & 4,914 & 4,207 & 4,217 & 5,661 & $5,295.9$ \\
\hline Asset & 9,010 & 9,483 & 10,286 & 9,596 & 9,533 & 11,436 & 10,796 \\
\hline Liabilities & $-5,013$ & $-5,257$ & $-5,372$ & $-5,389$ & $-5,316$ & $-5,775$ & $-5,500$ \\
\hline Of which: IMF liabilities & $-1,600$ & $-1,732$ & $-1,797$ & $-1,864$ & $-1,868$ & $-2,085$ & $-2,052$ \\
\hline Net Domestic Assets & 1 & 91 & -2 & 241 & 162 & -603 & -405 \\
\hline Net Domestic Claims & 254 & $\ldots$ & 334 & 1,288 & 362 & 1,522 & -205 \\
\hline Net Claims on Central Government & 861 & $\ldots$ & 1,375 & 1,217 & 956 & 1,451 & 956 \\
\hline Claims on Other Sectors & 43 & $\ldots$ & 64 & 60 & 64 & 60 & 64 \\
\hline Other Items (Net) & -196 & $\ldots$ & -223 & $-1,047$ & -200 & $-2,125$ & -200 \\
\hline Reserve money & 4,054 & 4,318 & 5,025 & 4,448 & 4,379 & 5,057 & 4,891 \\
\hline Currency outside banks and cash in vaults & 1,999 & $\ldots$ & 2,408 & 2,193 & 2,528 & 2,494 & 2,743 \\
\hline Other depository corporation reserves & 2,034 & $\ldots$ & 2,601 & 2,231 & 1,832 & 2,537 & 2,124 \\
\hline Liabilities To Other Sectors & 21 & $\ldots$ & 16 & 23 & 20 & 27 & 23 \\
\hline \multicolumn{8}{|l|}{ Memorandum items: } \\
\hline Reserve money (end-of-month, annual percent change) & 19.3 & 28.7 & 49.8 & 9.7 & 8.0 & 13.7 & 11.7 \\
\hline Broad Money (M3) (annual percent change) & 7.7 & 17.0 & 30.0 & 16.0 & 23.5 & 18.0 & 15.0 \\
\hline Credit to the private sector (annual percent change) & -5.7 & $\ldots$ & 3.0 & 15.5 & 14.0 & 15.5 & 18.3 \\
\hline Velocity (Nominal GDP/M3) & 4.7 & $\ldots$ & & 4.8 & 4.5 & 4.6 & 4.4 \\
\hline Money multiplier ( $\mathrm{M} 3 /$ reserve money) & 3.4 & 3.6 & 3.5 & 3.6 & 3.9 & 3.7 & 4.0 \\
\hline Credit to the private sector (percent of GDP) & 12.0 & $\ldots$ & $\ldots$ & 11.7 & 11.6 & 11.8 & 12.0 \\
\hline \multicolumn{8}{|l|}{ Gross foreign exchange reserves of the } \\
\hline Bank of Zambia (millions of U.S. dollars) & 1,758 & $\ldots$ & $\ldots$ & 1,849 & 1,886 & 2,378 & 2,158 \\
\hline Exchange rate (kwacha per U.S. dollar, end period) & 4,641 & $\ldots$ & $\ldots$ & $\ldots$ & $\ldots$ & $\ldots$ & $\ldots$ \\
\hline
\end{tabular}

Sources: Zambian authorities; and IMF staff estimates and projections.

${ }^{1}$ End of period. 
Table 5. Zambia: Balance of Payments ${ }^{1}$

(Millions of U.S. dollars, unless otherwise indicated)

\begin{tabular}{|c|c|c|c|c|c|c|c|}
\hline & 2009 & $\begin{array}{l}2010 \\
\text { Proj. }\end{array}$ & $\begin{array}{l}2011 \\
\text { Proj. }\end{array}$ & $\begin{array}{l}2012 \\
\text { Proj. }\end{array}$ & $\begin{array}{l}2013 \\
\text { Proj. }\end{array}$ & $\begin{array}{l}2014 \\
\text { Proj. }\end{array}$ & $\begin{array}{l}2015 \\
\text { Proj. }\end{array}$ \\
\hline Current account & -404 & -258 & -659 & $-1,270$ & $-1,392$ & $-1,462$ & $-1,557$ \\
\hline Trade balance & 906 & 2,117 & 1,152 & 432 & 236 & 324 & 333 \\
\hline Exports, f.o.b. & 4,319 & 6,850 & 6,679 & 6,335 & 6,580 & 7,524 & 8,127 \\
\hline Of which: copper & 3,179 & 5,455 & 5,232 & 4,816 & 4,712 & 5,195 & 5,325 \\
\hline Imports, f.o.b & $-3,413$ & $-4,733$ & $-5,527$ & $-5,903$ & $-6,344$ & $-7,200$ & $-7,794$ \\
\hline Of which: oil & -536 & -632 & -696 & -775 & -854 & -930 & $-1,032$ \\
\hline Services (net) & -465 & -647 & -798 & -870 & -881 & -935 & -991 \\
\hline Income (net) & $-1,361$ & $-2,167$ & $-1,423$ & $-1,302$ & $-1,224$ & $-1,333$ & $-1,391$ \\
\hline Of which: interest on public debt & -12 & -10.1 & -12 & -35 & -73 & -105 & -127 \\
\hline Current transfers (net) & 516 & 439 & 411 & 470 & 477 & 482 & 493 \\
\hline Budget support grants & 198 & 156 & 118 & 163 & 162 & 161 & 166 \\
\hline Sector-wide approach grants & 106 & 89 & 58 & 63 & 66 & 67 & 69 \\
\hline Private transfers & 212 & 194 & 235 & 245 & 249 & 254 & 258 \\
\hline Capital and financial account & 1,005 & 350 & 898 & 1,471 & 1,668 & 1,747 & 1,987 \\
\hline Capital account & 237 & 150 & 181 & 265 & 249 & 221 & 217 \\
\hline Project grants & 237 & 150 & 181 & 265 & 249 & 221 & 217 \\
\hline External debt cancellation & 0 & 0 & 0 & 0 & 0 & 0 & 0 \\
\hline Financial account & 768 & 200 & 717 & 1,207 & 1,419 & 1,526 & 1,770 \\
\hline Foreign direct and portfolio investments & 620 & 988 & 1,106 & 1,230 & 1,351 & 1,545 & 1,848 \\
\hline Other investments & 148 & -788 & -390 & -23 & 67 & -19 & -78 \\
\hline Medium and long-term & 148 & -788 & -390 & -23 & 67 & -19 & -78 \\
\hline Public sector (net) & 77 & 119 & 416 & 679 & 583 & 549 & 473 \\
\hline Disbursements & 119 & 162 & 507 & 742 & 638 & 580 & 506 \\
\hline Of which: budget support & 33 & 67 & 40 & 20 & 19 & 20 & 21 \\
\hline Amortization due & -43 & -43 & -91 & -63 & -55 & -31 & -33 \\
\hline Monetary authority ${ }^{2}$ & 627 & 0 & 0 & 0 & 0 & 0 & 0 \\
\hline Commercial banks (net) & -63 & -39 & 12 & -3 & 34 & 5 & 5 \\
\hline Other sectors & -493 & -867 & -818 & -699 & -550 & -573 & -555 \\
\hline Short-term & 0 & 0 & 0 & 0 & 0 & 0 & 0 \\
\hline Errors and omissions & -61 & 0 & 0 & 0 & 0 & 0 & 0 \\
\hline Overall balance & 540 & 92 & 239 & 201 & 276 & 285 & 430 \\
\hline \multicolumn{8}{|l|}{ Financing } \\
\hline Central bank net reserves (- increase) & -540 & -92 & -239 & -201 & -275 & -285 & -430 \\
\hline Of which: Gross reserve change & -782 & -147 & -272 & -189 & -257 & -250 & -360 \\
\hline Of which: Use of Fund resources & 242 & 55 & 34 & -12 & -18 & -35 & -69 \\
\hline Exceptional financing & 0 & 0 & 0 & 0 & 0 & 0 & 0 \\
\hline Financing gap & 0 & 0 & 0 & 0 & 0 & 0 & 0 \\
\hline \multicolumn{8}{|l|}{ Memorandum items: } \\
\hline Current account (percent of GDP) & -3.2 & -1.6 & -3.5 & -6.3 & -6.3 & -6.0 & -5.8 \\
\hline Current account, excluding grants (percent of GDP) & -5.5 & -3.2 & -4.5 & -7.4 & -7.3 & -7.0 & -6.7 \\
\hline Change in copper export volume (percent) & 16.0 & 11.2 & 10.1 & -1.6 & 6.0 & 10.3 & 2.5 \\
\hline Copper export price (U.S. dollars per tonne) & 5,165 & 7,100 & 6,950 & 6,500 & 6,000 & 6,000 & 6,000 \\
\hline Total official grants (percent of GDP) & 4.2 & 2.5 & 1.9 & 2.4 & 2.2 & 1.9 & 1.7 \\
\hline Gross international reserves ${ }^{3}$ & 1,758 & 1,886 & 2,158 & 2,348 & 2,605 & 2,855 & 3,215 \\
\hline In months of prospective imports & 3.7 & 3.4 & 3.6 & 3.7 & 3.6 & 3.7 & 3.7 \\
\hline GDP (millions of U.S. dollars) & 12,805 & 15,803 & 18,581 & 20,255 & 22,060 & 24,260 & 26,718 \\
\hline
\end{tabular}

Sources: Zambian authorities; and IMF staff estimates and projections.

${ }^{1}$ Disbursements and imports related to possible future hydropower projects are not included.

${ }^{2}$ SDR allocation, long term liability.

${ }^{3}$ Reserves are evaluated at market exchange rates. 
Table 6. Zambia: Financial Soundness Indicators

(Percent, unless otherwise indicated)

\begin{tabular}{|c|c|c|c|c|c|}
\hline & 2006 & 2007 & 2008 & 2009 & $\begin{array}{r}2010 \\
\text { Aug }\end{array}$ \\
\hline \multicolumn{6}{|l|}{ Capital adequacy } \\
\hline Regulatory capital to risk-weighted assets & 20.4 & 18.6 & 18.6 & 22.3 & 23.4 \\
\hline Tier 1 regulatory capital to risk-weighted assets & 18.0 & 15.9 & 15.7 & 18.9 & 20.3 \\
\hline Capital to total assets & 9.1 & 9.2 & 9.9 & 11.2 & 11.0 \\
\hline \multicolumn{6}{|l|}{ Asset quality } \\
\hline Past due advances (NPL) to total advances & 11.3 & 8.8 & 7.2 & 12.6 & 14.9 \\
\hline Loan loss provisions to nonperforming loans & 83.3 & 73.2 & 104.6 & 86.6 & 80.5 \\
\hline Bad debt provisions to advances & 6.8 & 6.4 & 6.1 & 10.9 & 12.0 \\
\hline \multicolumn{6}{|l|}{ Loan concentration } \\
\hline Households & 16.1 & 15.5 & 30.1 & 30.9 & 32.1 \\
\hline Government and parastatals & 6.2 & 9.1 & 1.9 & 3.1 & 1.8 \\
\hline Agriculture & 23.9 & 18.4 & 16.0 & 19.0 & 17.0 \\
\hline Mining & 4.4 & 4.1 & 5.0 & 4.0 & 3.0 \\
\hline Manufacturing & 14 & 11.0 & 11.0 & 12.0 & 14.0 \\
\hline Construction & 2.4 & 3.7 & 4.0 & 3.0 & 4.0 \\
\hline Services & 9.8 & 13.3 & 9.0 & 8.0 & 6.0 \\
\hline Others & 23.2 & 25.0 & 23.0 & 20.0 & 22.1 \\
\hline \multicolumn{6}{|l|}{ Earnings and profitability } \\
\hline Return on average assets & 5.1 & 4.7 & 3.6 & 2.1 & 2.8 \\
\hline Return on equity & 30.6 & 35.1 & 20.8 & 9.4 & 14.0 \\
\hline Gross interest income to total gross income & 60.2 & 63.1 & 66.6 & 65.1 & 60.8 \\
\hline Gross noninterest income to total gross income & 39.8 & 36.9 & 33.4 & 34.9 & 39.2 \\
\hline Net interest margin & 12.8 & 11.5 & 10.4 & 10.7 & 9.9 \\
\hline \multicolumn{6}{|l|}{ Liquidity } \\
\hline Liquid assets to total assets & 41.3 & 37.6 & 35.5 & 38.0 & 43.4 \\
\hline Liquid assets to total deposits & 49.6 & 46 & 49.9 & 52.6 & 57.8 \\
\hline Advances to deposits ratio & 49 & 57.4 & 66.3 & 60.1 & 51.8 \\
\hline \multicolumn{6}{|l|}{ Exposure to foreign currency } \\
\hline Foreign currency loans to total gross loans & 34.0 & 32.5 & 42.1 & 36.4 & 35.1 \\
\hline Foreign currency liabilities to total liabilities & 61.2 & 27.1 & 35.8 & 38.0 & 37.7 \\
\hline Net open position in foreign exchange to capital & 9.4 & 7.1 & 6.9 & 2.5 & 5.4 \\
\hline
\end{tabular}

Source: Bank of Zambia. 
Table 7. Zambia: Indicators of Capacity to Repay the Fund

\begin{tabular}{|c|c|c|c|c|c|c|c|}
\hline & 2010 & 2011 & 2012 & 2013 & 2014 & 2015 & 2016 \\
\hline \multicolumn{8}{|l|}{$\begin{array}{l}\text { Fund obligations based on existing credit } \\
\text { (in millions of SDRs) }\end{array}$} \\
\hline Principal & 0.6 & 3.3 & 7.7 & 11.7 & 23.1 & 43.4 & 44.4 \\
\hline Charges and interest & 0.1 & 0.2 & 0.8 & 0.8 & 0.7 & 0.6 & 0.5 \\
\hline \multicolumn{8}{|c|}{$\begin{array}{l}\text { Fund obligations based on existing and prospective credit } \\
\text { (in millions of SDRs) }\end{array}$} \\
\hline Principal & 0.6 & 3.3 & 7.7 & 11.7 & 23.1 & 43.4 & 49.9 \\
\hline Charges and interest & 0.1 & 0.2 & 0.9 & 0.8 & 0.8 & 0.7 & 0.6 \\
\hline \multicolumn{8}{|l|}{ Total obligations based on existing and prospective credit } \\
\hline In millions of SDRs & 0.6 & 3.5 & 8.6 & 12.5 & 23.9 & 44.2 & 50.5 \\
\hline In millions of US\$ & 0.9 & 5.3 & 13.0 & 19.1 & 36.4 & 67.4 & 77.0 \\
\hline In percent of exports of goods and services & 0.0 & 0.1 & 0.2 & 0.3 & 0.5 & 0.8 & 0.8 \\
\hline In percent of debt service ${ }^{1}$ & 1.7 & 4.9 & 11.9 & 13.1 & 21.2 & 29.5 & 29.7 \\
\hline In percent of GDP & 0.0 & 0.0 & 0.1 & 0.1 & 0.2 & 0.3 & 0.3 \\
\hline In percent of Gross International Reserves & 0.0 & 0.2 & 0.6 & 0.7 & 1.3 & 2.1 & 2.1 \\
\hline In percent of quota & 0.1 & 0.7 & 1.8 & 2.6 & 4.9 & 9.0 & 10.3 \\
\hline \multicolumn{8}{|l|}{ Outstanding Fund credit } \\
\hline In millions of SDRs & 256.2 & 271.3 & 263.6 & 251.9 & 228.8 & 185.3 & 135.5 \\
\hline In millions of US\$ & 388.4 & 412.4 & 401.1 & 383.8 & 349.0 & 282.7 & 206.6 \\
\hline In percent of exports of goods and services & 5.4 & 5.9 & 6.0 & 5.5 & 4.4 & 3.3 & 2.1 \\
\hline In percent of debt service ${ }^{1}$ & 717.3 & 380.5 & 365.3 & 264.1 & 203.0 & 123.7 & 79.7 \\
\hline In percent of GDP & 2.5 & 2.2 & 2.0 & 1.7 & 1.4 & 1.1 & 0.7 \\
\hline In percent of Gross International Reserves & 20.6 & 19.1 & 17.1 & 14.7 & 12.2 & 8.8 & 5.6 \\
\hline In percent of quota & 52.4 & 55.5 & 53.9 & 51.5 & 46.8 & 37.9 & 27.7 \\
\hline Net use of Fund credit (in millions of SDRs) & 36.2 & 22.1 & -7.7 & -11.7 & -23.1 & -45.3 & -49.9 \\
\hline Disbursements & 36.8 & 25.4 & 0.0 & 0.0 & 0.0 & 0.0 & 0.0 \\
\hline Repayments & -0.6 & -3.3 & -7.7 & -11.7 & -23.1 & -45.3 & -49.9 \\
\hline \multicolumn{8}{|l|}{ Memorandum items: } \\
\hline Exports of goods and services (in millions of US\$) & 7,144 & 7,024 & 6,712 & 6,991 & 7,975 & 8,624 & 9,749 \\
\hline Debt service (in millions of US $\$)^{1}$ & 54 & 108 & 110 & 145 & 172 & 228 & 259 \\
\hline Nominal GDP (in millions of US\$) & 15,803 & 18,581 & 20,255 & 22,060 & 24,260 & 26,718 & 29,506 \\
\hline Gross International Reserves (in millions of US\$) & 1,886 & 2,158 & 2,348 & 2,605 & 2,855 & 3,216 & 3,658 \\
\hline Quota (millions of SDRs) & 489 & 489 & 489 & 489 & 489 & 489 & 489 \\
\hline
\end{tabular}

Sources: IMF staff estimates and projections.

${ }^{1}$ Total central government debt service; it includes IMF repayments. 
Table 8. Zambia: Schedule of Disbursements Under the ECF Arrangement ${ }^{1}$

\begin{tabular}{|c|c|c|c|}
\hline \multirow[t]{2}{*}{ Availability } & \multicolumn{2}{|c|}{ Current } & \multirow[t]{2}{*}{ Conditions for Disbursement } \\
\hline & $\begin{array}{l}\text { Millions } \\
\text { of SDRs }\end{array}$ & $\begin{array}{l}\text { Percent } \\
\text { of quota }\end{array}$ & \\
\hline June 4, 2008 & 6.987 & 1.429 & Board approval of the three-year ECF arrangement \\
\hline November $30,2008^{2}$ & 6.987 & 1.429 & $\begin{array}{l}\text { Board completion of the first review based on observance } \\
\text { of performance criteria for June } 30,2008\end{array}$ \\
\hline May $1,2009^{2}$ & 99.923 & 20.430 & $\begin{array}{l}\text { Board completion of the first and second review based on observance } \\
\text { of performance criteria for June } 30 \text { and December } 31,2008\end{array}$ \\
\hline November 30, 2009 & 51.013 & 10.430 & $\begin{array}{l}\text { Board completion of the third review based on observance } \\
\text { of performance criteria for June } 30,2009\end{array}$ \\
\hline June 30, 2010 & 18.395 & 3.761 & $\begin{array}{l}\text { Board completion of the fourth review based on observance } \\
\text { of performance criteria for December 31, } 2009\end{array}$ \\
\hline November 30, 2010 & 18.395 & 3.761 & $\begin{array}{l}\text { Board completion of the fifth review based on observance } \\
\text { of performance criteria for June } 30,2010\end{array}$ \\
\hline May 15, 2011 & 18.395 & 3.761 & $\begin{array}{l}\text { Board completion of the sixth review based on observance } \\
\text { of performance criteria for December } 31,2010\end{array}$ \\
\hline Total disbursements & 220.095 & 45.0 & \\
\hline
\end{tabular}

Source: IMF staff estimates.

${ }^{1}$ Original ECF disbursements of SDR 48.91 million (10 percent of quota) during 2008-11; and augmentation of SDR 171.2 million (35 percent of quota) during 2009-11; in total, SDR 220.1 million (45 percent of quota) during 2008-11.

${ }^{2}$ Disbursement made available upon completion of the first and second reviews on May 1, 2009. 
APPENDIX I. LETTER OF INTENT

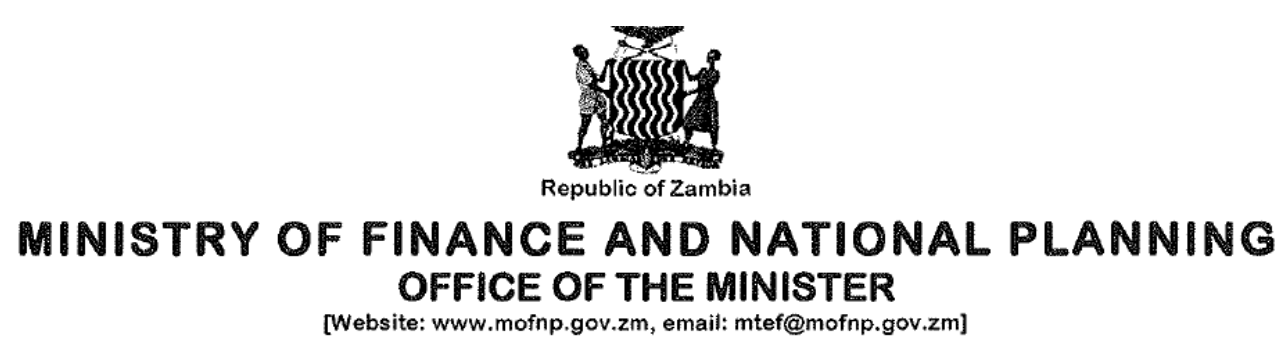

REF: MFAL/102/12/932

November 24, 2010

Mr. Dominique Strauss-Kahn

Managing Director

International Monetary Fund

Washington, D.C. 20431

USA

Dear Mr. Strauss-Kahn,

The attached Memorandum of Economic and Financial Policies (MEFP) reviews recent economic developments and progress in implementing the Government of the Republic of Zambia's macroeconomic and structural program under the country's three-year arrangement under the Extended Credit Facility (ECF), approved by the IMF Executive Board on June 4, 2008. It also sets out macroeconomic policies and structural reforms the government will pursue for the remainder of 2010 and for 2011.

The Government requests that the sixth disbursement be made available upon completion of the fifth review by the Executive Board of the IMF. All of the performance criteria for the fifth review under the ECF arrangement were met. We request a waiver for the nonobservance of the end-December 2009 nonconcessional debt ceiling.

Structural reforms are progressing well. The structural benchmark for end-September 2010 on the review of tax administration and policy was met, and we are requesting a modification of the definition (but not the substance) of the end-December 2010 benchmark on the Treasury Single Account owing to a change in our approach. We are requesting a one-month delay in the timing of the benchmark for the planning and budgeting act to end-January 2011, in order to allow for further consultations. While the lender-of-last resort framework was in place by end-June 2010 (thus meeting that portion of the related benchmark), the submission 
of relevant draft legislation on the financial sector contingency plan will take more time to allow a full set of consultations with stakeholders. We are now aiming to submit the draft legislation to parliament by end-May 2011.

The Government believes that by adhering to the policies and measures set forth in the attached MEFP, it is well placed to achieve the objectives of the program. We updated the economic program for the remainder of 2010 to take into account recent developments, including the government's role in the purchase of the surplus maize, and we request modifications to the end-December 2010 performance criteria. The policies and measures detailed in the MEFP for 2011 are solid and consistent with achieving the objectives of the program. We request that the ceiling on nonconcessional borrowing be shifted from a project basis to a sectoral basis.

The Government is firmly committed to the objectives of the program and will promptly take any additional measures necessary for their achievement. The Government remains committed to regular consultations with the IMF - at our own initiative or whenever the Managing Director of the IMF requests such a consultation - on the adoption of these measures and in advance of revisions to the policies contained in the MEFP, in accordance with the Fund's policies on such consultations.

The Government authorizes the IMF to publish this letter, the attached Memorandum of Economic and Financial Policies, and the related Staff Report, including placement of these documents on the IMF website subject to the removal of market-sensitive information, following the IMF Executive Board's conclusion of the review.

Yours sincerely, $/ \mathrm{s} /$

Dr. Situmbeko Musokotwane

Minister of Finance and National Planning

Attachments: - Memorandum of Economic and Financial Policies

- Technical Memorandum of Understanding for the 2010-11 Extended Credit Facility (ECF) arrangement 


\section{Attachment I. Zambia: Memorandum of Economic and Financial Policies}

1. This memorandum reviews recent economic developments and outlines policies that the government of the Republic of Zambia will pursue for the remainder of 2010 and for 2011 under the Extended Credit Facility (ECF) arrangement.

2. The ECF supports the implementation of the second half of the Fifth National Development Plan 2006-10 (FNDP). The FNDP underscores the need to create an environment conducive to private sector growth through sustained macroeconomic stability, public sector efficiency and accountability, and investments in infrastructure and social sectors. The program is consistent with these principles and objectives, and has focused on maintaining macroeconomic stability; creating fiscal room for investments in the roads, energy, and social sectors; and removing constraints to private sector-led growth and to economic diversification away from copper mining.

3. The government expects to launch its Sixth National Development Plan 2011-15 (SNDP) by end-December 2010. The areas of emphasis under the SNDP are the two main binding constraints to growth and poverty reduction: inadequate infrastructure and human development. Investments in these areas will be increased in line with the government's strategic objectives of accelerating economic diversification and meeting its Millennium Development Goals. The SNDP will also improve the effectiveness of government planning and spending by taking on board lessons gained from the implementation of the FNDP.

\section{RECENT ECONOMIC DEVELOPMENTS}

4. Growth in the Zambian economy is expected to be higher than projected earlier. Revised projections indicate that real GDP growth in 2010 will be 6.6 percent on the back of the continued strength of the agriculture, mining, and construction sectors, and a rebound in the tourism sector. The 2010 agricultural harvest was the highest recorded in history. Mining benefitted from higher-than-expected copper prices, which were more than 41 percent higher than in 2009. Tourism, aided by recovery in the world economy, the FIFA World Cup in South Africa, and the reduction in visa fees, experienced a strong rebound from the negative growth in 2009. Gross international reserves are expected to rise to above US\$1.9 billion (net of encumbered reserves) at end-2010, equivalent to $3 \frac{1}{2}$ months of prospective imports. The growth in reserves largely reflected net proceeds from the sale of Zamtel and increased mining receipts. Inflation has largely remained under control as a result of lower food prices. Zambia remains on track to achieve its end-year inflation target of 8 percent, although there remain some downside risks as a result of non-food inflationary pressures arising from an increase in energy prices.

5. Fiscal performance in $\mathbf{2 0 1 0}$ was broadly in line with expectations, other than the need to address the maize purchase late in the year. As of end-September 2010, domestic revenues had performed well, and are expected to over perform by 9 percent by the end of the year. This performance is attributed to higher collections under income and value added taxes 
arising from the collection of tax arrears and an increase in tax collections from mining companies. Total expenditure was 7 percent higher than budgeted, as Government faced additional expenditure pressures, which included transfers to the Food Reserve Agency (FRA) in order to finance maize purchases, the fuel subsidy early in 2010, which has since been removed, and numerous by-elections. In order to finance these activities, the overall fiscal deficit (including grants) is projected at 3.3 percent of GDP, higher than the program target of 2.5 percent of GDP.

6. The country recorded an unprecedented maize harvest of nearly 2.8 million metric tonnes in 2010. The budgetary allocation to FRA was inadequate to buy all the surplus maize from small-scale farmers. As the domestic market could only absorb 2 million metric tonnes, Government (through FRA) decided to buy 800,000 metric tonnes at a cost of K 1,301 billion (about 1.7 percent of GDP), so as to avoid the crop going to waste by remaining unsheltered in the fields with the onset of the rainy season. Purchase of the maize will be financed using K495 billion of mining tax arrears, K 402 billion of additional sales of government securities, $\mathrm{K} 95$ billion using a bridge loan from the Bank of Zambia, K 150 billion from the 2010 budgetary allocation, and K179 billion of FRA borrowing from Commercial Banks. The Bank of Zambia is committed to undertake sterilization operations to ensure that its liquidity injection does not fuel inflation. In order to recover part of these funds, FRA intends to sell the bulk of the maize to deficit countries in the region in 2011 and thereafter, and repay the government.

\section{The implementation of monetary policy during the first half of 2010 was in line} with the program, though broad money growth was higher than expected. Broad money stood at K 16,065 billion at end-June 2010, growing at 24.5 percent on a 12-month basis. The higher broad money growth reflects a recovery in domestic credit and increased net foreign assets of commercial banks consistent with the improvement in external performance. Reserve money stood at K4,183 billion at end-June, growing at 24 percent on a 12-month basis. This was within the indicative target of K 4,277 billion for end-June 2010. By the end of 2010, reserve money is projected to grow by 8 percent to $\mathrm{K} 4,380$ billion from the end-December 2009 level of K 4,054 billion. Growth of credit to the private sector, though sluggish in 2009, began to recover posting a 7.6 percent growth during the first six months of 2010 and is expected to grow by 15 percent during the whole of 2010 .

8. The balance of payments position continued to improve during the first half of 2010, as copper exports remained high. A current account surplus of US\$203.7 million was recorded compared with a deficit of US\$284.8 million during the same period in 2009, explained by increased copper and cobalt export volumes and the recovery of metal prices on the international market. The overall balance of payments deficit, however, widened to US $\$ 175.7$ million from US\$121.3 million recorded during the corresponding period in 2009, largely on account of a rise in assets held abroad by the private sector. As a result, the international reserves position stood at US\$1.6 billion at end-June 2010, rising further to about US\$1.9 billion as of October 21, 2010. 
9. The supply of petroleum products during the year was reliable and stable. This was on account of Government entering into long-term supply contracts for the supply of fuel. Following the reinstatement of full cost recovery pricing of petroleum products, domestic prices for petroleum products were adjusted twice by an average of 15 percent and 12.2 percent in January and May 2010 respectively. Other developments included the introduction of uniform prices for domestic petroleum products across the country.

10. The program was on track during the first half of 2010 (Tables 1 and 2). All quantitative performance criteria and indicative targets were met. However, the payment of domestic arrears was less than the indicative target on domestic arrears clearance. Government policy on the payment of arrears stipulates that payment only be made for cases that have cleared the pre-requisite investigation and verification process. As such, the remaining arrears by the Government are for cases that have yet to clear this process. With regard to structural reforms, Cabinet approved the pay policy reform in the first half of 2010 . The new policy aims at strengthening payroll management and increasing the productivity of the public sector by putting in place an incentive-based pay structure. The benchmark on electricity tariffs was met (with a modest delay of under 4 weeks), with tariffs being raised by an average of 25.6 percent in July 2010. The benchmark on the establishment of a lender of last resort framework was partly met, with some delays occurring in the preparation of draft legislation governing the financial sector contingency planning in the event of a financial crisis. The delays were on account of the consultation process taking longer than expected. It is expected that the relevant draft legislation will be submitted to parliament by end-May 2011.

\section{MEDIUM-Term MACROECONOMIC FrAMEWORK}

\section{Medium-term growth projections have been revised upwards from earlier} estimates, as a result of recent economic developments. Real GDP growth in 2011 has been revised upwards to 6.4 percent from an earlier projection of 6.0 percent. Growth in 2011 will continue to be driven by the mining sector and aided by continued growth in the construction sector. Investments in the reopened Luanshya Copper Mine have been accelerated and copper production is expected to increase in 2011. The development of another new copper mine is expected to continue in 2011, and there has been an increase in exploration activities for a variety of mineral resources, including copper, nickel and uranium. A revival in manufacturing, which suffered from the effects of the global crisis, is also expected in 2011. Medium-term growth continues to be premised on the attainment of government policy initiatives aimed at promoting economic diversification and dismantling structural constraints to doing business. New energy and mining projects are expected to underpin medium-term growth projections.

\section{In order to finance investments in infrastructure and in the social sectors, the} fiscal policy stance will remain broadly unchanged over the next few years. This stance will remain consistent with debt sustainability, so as to safeguard macroeconomic stability and leave room for private sector borrowing. Over the period 2011-13, the overall fiscal deficit (including grants) is expected to remain broadly unchanged at an average of 3.4 percent of 
GDP, compared to 3.3 percent in 2010. In order to address the challenge of increasing revenues to the Treasury, a comprehensive reform of the current tax system will be undertaken (drawing on a review of the tax system) with the aim of increasing compliance and broadening the tax base. The reform will focus both on improving the tax system and modernising tax administration. Some key milestones will include the implementation of an Integrated Domestic Taxes Administration System; development of the Tax Administration Act; and upgrading of communication infrastructure to streamline operations and improve service delivery.

\section{POLICIES FOR 2011}

\section{A. Fiscal Policy}

13. Within the framework of an increased fiscal space, fiscal policy will aim to increase spending on infrastructure and the social sectors. Revenues are projected to increase to 18.4 percent of GDP, mainly on account of an increase in nonmining company tax, withholding tax and VAT on domestic goods and services. VAT will be increased through the introduction of tax measures aimed at increasing compliance and broadening the tax base. Some of the measures will include standard rating of property and casualty insurance, as well as fee based banking services for VAT purposes. The Government believes the current mining tax regime is fair, equitable and buoyant enough to provide adequate revenues to the Government. The Government's focus will now be to fully enforce this tax and ensure that all the mining companies pay in accordance with the current laws. Expenditures will decline by about $2 / 3$ of a percentage point to 23.4 percent of GDP, with 3.6 percentage points financed using foreign grants and loans. The wage bill will remain at 8.3 percent of GDP, with tight limits on new hiring (limited to teachers, medical personnel, and police officers) and a temporary freeze on replacing staff that leave the civil service. Financing for the social sectors and infrastructure development is projected to increase to 50 percent of the budget, compared to a projected outturn of 36 percent in 2010. The overall fiscal deficit (including grants) is projected to decline by 0.1 percentage points to 3.2 percent of GDP, while domestic financing will be limited to 1.4 percent of GDP.

\section{B. Monetary and Exchange Rate Policies}

\section{The Government will aim at reducing inflation to 7 percent by the end of 2011 .} Broad money is projected to expand by 15 percent, broadly in line with nominal GDP. The money multiplier is expected to increase gradually as the trend decline in ratio of currency in circulation to deposits continues. Consistent with this, reserve money is targeted to grow by 11.7 percent during 2011. Short-term interest rates are expected to return to positive real levels and the yield curve is expected to flatten.

15. The current reserve money-based program will remain in place, while at the same time progress is being made towards the use of interest rates as the main instrument to anchor inflationary expectations. The Bank of Zambia is in the process of developing an operational 
framework to ensure a smooth eventual migration. The Bank will draw on technical assistance from the IMF to ensure the adoption of international best practices.

16. The government will continue to maintain a flexible exchange rate regime. Interventions in the foreign exchange market will be limited to smoothing excessive fluctuations, while allowing for a gradual build up of international reserves.

\section{Structural Policies}

\section{Public financial management}

17. The Government remains committed to improving the management of public finances. Progress has been made in preparing the draft Planning and Budgeting Act for submission to Parliament. A series of consultations with stakeholders is likely to delay its submission to parliament to end-January 2011.

\section{The pilot implementation of the Integrated Financial Management System} (IFMIS) has been successful in its first pilot site. IFMIS has been in use at the Ministry of Finance and National Planning since January 2010, with most financial transactions being processed through the new system. The system is still facing challenges in the funds (budget) management module, which are expected to be resolved by the end of 2010. The rollout of IFMIS to the next seven MPSAs is now scheduled to be done at the beginning of 2011, to coincide with the beginning of the new financial year. This will ease the challenge of financial transactions for the same year being processed in two different systems. The implementation in other MPSAs will be implemented in similar cycles, that is, at the beginning of quarters or half year.

\section{Work is ongoing in implementing the Treasury Single Account (TSA) across all} Ministries, Provinces and Spending Agencies (MPSAs). The implementation of the TSA has been done by expenditure category, instead of by MPSA as initially planned due to challenges faced in the full rollout of IFMIS. The implementation by expenditure category has also permitted the safeguarding of the majority of public expenditure across Government. As at end-September 2010, over 98 percent of the monthly wage bill, as well as grants for the Ministry of Finance and National Planning was paid through the TSA, representing 35 percent of total budgeted expenditure from the Government. Over the next three months, all grants, capital payments and external debt (principal, interest and other related payments) will be processed through the TSA. In this regard, validation of bank accounts for grant aided institutions will be carried out to facilitate payment of grants. Certified certificates of completion of works will also be submitted to the Treasury for processing through the TSA. In view of this new approach to rolling out the TSA, the end-December structural benchmark is being amended to reflect four key categories of expenditure (namely: wages, grant-financed outlays, capital spending, and debt service), representing 67 percent of the total budget. The Government remains committed to the full rollout of the TSA, but this will require the implementation of IFMIS across all MPSAs. 
20. Progress is being made in the development of a successor program to the Public Expenditure Management and Financial Accountability (PEMFA) project. A full review of PEMFA was recently undertaken, and a number of shortcomings and challenges have been highlighted. Discussions are ongoing with Cooperating Partners to develop a successor program. While details of the draft successor program are still being developed, the new program is expected to continue on the foundations built by the PEMFA project.

\section{Financial sector development}

21. The government remains committed to the development of the financial sector through the implementation of the second phase of the Financial Sector Development Plan (FSDP II), which runs from January 2010 to December 2012. The FSDP Phase II focuses on three main pillars, namely, (i) enhancing market infrastructure; (ii) increasing competition; and (iii) increasing access to finance. The FSDP Phase II is envisaged to deal with outstanding and long-term issues including the harmonisation of financial sector laws, enhancement of financial education and the formal financial safety net (through development of a Deposit Protection Scheme), establishment of the sovereign credit rating, as well as the implementation of a national switch.

22. The Bank of Zambia revised its lender of last resort policy by end-June 2010 to align it with accepted international standards and ensure its effectiveness and relevance. Progress is also being made towards the implementation of the financial sector contingency plan to address the impact of a system-wide crisis in the financial sector and the broader economy.

\section{Maize}

23. The Government is well aware of the challenges that have arisen from financing this year's maize surplus. It is therefore determined to handle any future surpluses in a way that minimizes the risk posed to the budget, to private sector credit and to financial stability. In this regard, the Government has appointed a committee of senior officials to examine the current maize marketing, and pricing mechanisms so as to better serve the Zambian people. The committee will specifically establish a pricing system for maize that is reflective of market conditions and will act as an incentive to the farmer, setup a purchasing arrangement for maize in both deficit and surplus times while limiting budgetary exposure, submit a financing plan for maize purchase for 2010/11 and ascertain and document storage capacity in the country. The committee will conduct its business within a period of three months and make recommendations to Cabinet. The submission of the committee's report to cabinet by endMarch 2011 will constitute a structural benchmark in the program.

\section{Energy}

24. The Government is committed to making further progress in 2011 towards achieving cost reflective electricity tariffs by 2012. While Zesco has been given an 
indicative tariff increase of 17 percent for 2011, the Energy Regulation Board (ERB) Act requires Zesco to formally apply for the tariff increase each year. The application is subjected to public hearings and evaluation of the company's performance under the ERB/Zesco agreed Key Performance Indicators. The outcome of the two exercises will determine the actual level of increase.

25. The policy of cost reflective pricing for petroleum will be maintained in 2011. The Government will adjust the prices of petroleum products to reflect the cost of each shipment. This will enable the Government to avoid the accumulation of deficits.

26. The development of the Kafue Gorge Lower Project is now expected to commence in mid-2011. The Government recently signed a Memorandum of Understanding with the Sinohydro Corporation for the development of the project. Work is already underway to develop access roads to the facility, and geotechnical sampling work has commenced. The project will be developed through a public-private partnership, which will involve 35 percent equity participation from the Zambian Government (approximately US\$200 million). Generation is expected to come on-stream by 2017 and will add over 600MW of electricity. Work is also continuing on the development of the Kariba North Bank Extension project, which is likely to be completed in 2013. A number of other public and private sector minihydro facilities will also be developed over the medium term, with the aim of increasing total power generation and rural access to electricity.

\section{Governance}

27. The Government remains committed to resolving outstanding issues that have delayed the disbursement of Cooperating Partner resources. In particular, revelations of financial management irregularities, first in the Health sector in 2009, and then in the Roads sector this year, have lead to delays in donor disbursements. As a result, significant shortfalls in donor financing, including budget support, are expected in 2010. The Government has resolved all outstanding issues with Cooperating Partners and expects a resumption of disbursements.

28. The Government remains committed to fully addressing the governance challenges in the roads sector. On the basis of the special audit of the Road Development Agency (RDA) by the Auditor General's office, corrective actions to remedy the financing and administrative anomalies have been undertaken. For a start, the Boards of the RDA and NFRA were disbanded and replaced and disciplinary actions taken against some members of staff. Additionally, measures are being undertaken to enhance inter-agency coordination. Further, the Government will, by the end of 2010, enhance capacity in internal audit, procurement, financial management and monitoring activities at the Road Development Agency. Currently, Government is working with Stakeholders to draw-up a bankable ROADSIP II programme.

29. Government is continuing to make progress under the health sector governance action plan. After completing a first round of actions that resulted in a partial release of 
cooperating partner sectoral funds, progress is being made on indicative medium-term actions that will trigger the disbursement of second tranche funds. These include the strengthening of financial management, accounting and procurement functions. In this regard a financial, procurement, and systems audit was commissioned and is expected to be completed in November 2010. Based on the recommendations of the audit, the Government in collaboration with Cooperating Partners will develop a plan for strengthening accountability and financial controls in the Ministry of Health. In the meantime, the Government is strengthening internal audit, accounting, and procurement functions, including the fiduciary function of management, through constant training of staff in short- and long-term courses. Further, the Audit Committee at the Ministry, with external members, has been constituted and has been having regular meetings to provide financial oversight. The Office of the Auditor General has continued to give support to internal audit by carrying out pre- and postaudit exercises and quarterly review of expenditure.

\section{Debt and debt management}

30. In line with national development priorities, Government will scale up investment in infrastructure in order to keep up with the ever increasing infrastructure demand of its growing economy. To this end and considering the level of investment required, Government intends to finance projects with high economic and social returns through concessional and nonconcessional external borrowing. Government will ensure that all borrowing is within sustainable limits. In the context of the program, Government would like to shift from nonconcessional borrowing tied to specific projects to a sector-based approach (focusing on electricity and roads), while adhering to the overall ceilings on nonconcessional borrowing in the program, Strengthening debt management and project appraisal capacity will be a key ingredient to this approach.

\section{The Government sees room for improvement in the existing debt management} capacity in the debt department and will strengthen it accordingly. It is therefore taking measures to strengthen its capacity by reorganizing staff in the external debt recording unit and external debt management unit through staff movements. The upcoming restructuring, in 2011, along functional lines into what will become the debt management office will be in line with international best practices. Over the medium term, the staff will be trained and retrained in debt management with the assistance multilateral capacity building institutions. Further, Government will embark on a reconciliation exercise for the electronic and manual debt data to improve accuracy. The Government will consult IMF staff to determine the concessionality of new loans prior to signing.

\section{The Government will continue consolidating its capacity in carrying out project}

appraisals. It is essential that scarce resources are applied to projects that have a high economic rate of return and have the most social and economic benefit to the people. In addition, Government will continue carrying out feasibility studies to ensure that projects have least impact on the natural environment, and communities. In cases where capacity to carry out 
project appraisal and feasibility studies are inadequate, the Government will continue contracting private sector experts. In the medium term, the Government has been offered grant financing by the Development Bank of Southern Africa to assist SADC countries to prepare comprehensive project appraisals for projects identified under the SNDP. This will ensure value for money.

33. Considerable progress has been made in the capturing and recording of aid data. As a result of substantial efforts involving both Government and Cooperating Partners, the Government will, in 2010, publish its first Development Cooperation Report, which is expected to provide details on aid flows from Cooperating Partners. The Government is working with Cooperating partners to ensure the accuracy and reliability of the data.

\section{Program Monitoring}

34. Semi-annual disbursements under the ECF arrangement will be based on the observance of quantitative performance criteria. Completion of the sixth review under the arrangement will be based on the observance of quantitative performance criteria through endDecember 2010 (Tables 1 and 2). The sixth review is expected to be completed by end-May 2011. 
MEFP Table 1. Zambia: Quantitative Performance Criteria (PC) and Indicative Targets, $2010^{1}$

(Billions of kwacha, unless otherwise indicated)

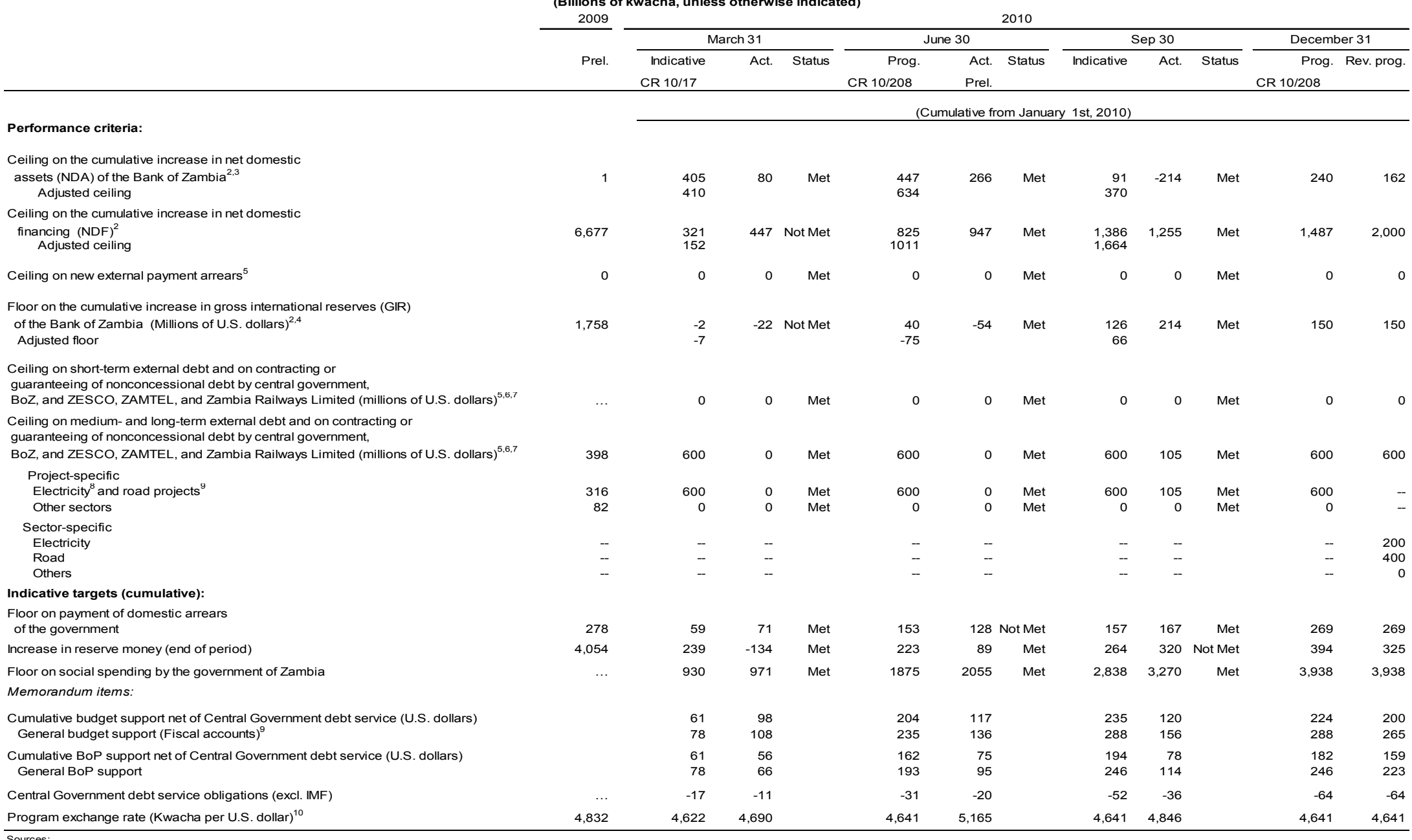

Sources:
'The definitions of the items in the quantitative program are contained in the Technical Memorandum of Understanding (TMU)
2Adiustors, including for general budget support, are defined in the TMU

ts as specified in the TMU.

The ceiling will be adjusted for changes in the legal $\mathrm{r}$.
"Reserves are calculated at program exchange rates.

Continuous performance criteria and cumulative from the beginning of 2010.

Up until the privatization of ZAMTEL on June 5, 2010.

80 The electricity projects are: Kariba North bank extension, Itezhi-Tenzi power station, Kafue Gorge Lower;
"The road projects are: Mutanda-Chavuma Road, Choma-Chitongo-Nam

${ }^{9}$ The road projects are: Mutanda-Chavma Road, Choma-Chitongo-Namwala Road, Kasama-Luwingu Road.
10 This exchange rate is not a projection but a rate (fixed at the level of end-2009) that is used for the calculation of program targets, as specified in the Technical Memorandum of Understanding. 
MEFP Table 2. Zambia: Targets, $2011^{1}$

(Billions of kwacha, unless otherwise indicated)

\begin{tabular}{|c|c|c|c|c|c|}
\hline & \multirow{2}{*}{2010} & \multicolumn{4}{|c|}{2011} \\
\hline & & $\begin{array}{l}\text { March } 31 \\
\text { Indicative } \\
\text { Target }\end{array}$ & $\begin{array}{l}\text { June } 30 \\
\text { Target }^{2}\end{array}$ & $\begin{array}{l}\text { Sep } 30 \\
\text { Target }^{2}\end{array}$ & $\begin{array}{l}\text { Dec } 31 \\
\text { Target }^{2}\end{array}$ \\
\hline & & \multicolumn{4}{|c|}{ (Cumulative from January 1st, 2011) } \\
\hline $\begin{array}{l}\text { Celling on the cumulative increase in net domestic } \\
\text { assets (NDA) of the Bank of Zambia }\end{array}$ & 162 & -337 & -129 & -319 & -567 \\
\hline $\begin{array}{l}\text { Ceiling on the cumulative increase in net domestic } \\
\text { financing (NDF) }\end{array}$ & 8,677 & 284 & 805 & 1,278 & 1,221 \\
\hline $\begin{array}{l}\text { Floor on the cumulative increase in gross international reserves (GIR) } \\
\text { of the Bank of Zambia (Millions of U.S. dollars) }\end{array}$ & 1,909 & 42 & 64 & 142 & 272 \\
\hline Ceiling on new external payment arrears ${ }^{6}$ & 0 & 0 & 0 & 0 & 0 \\
\hline $\begin{array}{l}\text { Ceiling on short-term external debt and on contracting or } \\
\text { guaranteeing of nonconcessional debt by central government, } \\
\text { BoZ, and ZESCO, and Zambia Railways Limited (millions of U.S. dollars) }\end{array}$ & $\ldots$ & 0 & 0 & 0 & 0 \\
\hline $\begin{array}{l}\text { Ceiling on medium- and long-term external debt and on contracting or } \\
\text { guaranteeing of nonconcessional debt by central government, }\end{array}$ & & & & & \\
\hline $\begin{array}{l}\text { BoZ, and ZESCO, and Zambia Railways Limited (millions of U.S. dollars) } \\
\text { Sector-specific }\end{array}$ & $\ldots$ & 800 & 800 & 800 & 800 \\
\hline $\begin{array}{l}\text { Electricity } \\
\text { Road projects }\end{array}$ & $\ldots$ & $\begin{array}{l}400 \\
400\end{array}$ & $\begin{array}{l}400 \\
400\end{array}$ & $\begin{array}{l}400 \\
400\end{array}$ & $\begin{array}{l}400 \\
400\end{array}$ \\
\hline $\begin{array}{l}\text { Floor on payment of domestic arrears } \\
\text { of the government }\end{array}$ & 269 & 79 & 150 & 229 & 316 \\
\hline Increase in reserve money (end of period) & 4,379 & -21 & 318 & 444 & 512 \\
\hline Floor on social spending by the government of Zambia & 3,938 & 1,385 & 2,769 & 4,154 & 5,385 \\
\hline Memorandum items: & & & & & \\
\hline Cumulative budget support net of Central Government debt service (U.S. dollars) & 170 & 26 & 2 & 26 & 55 \\
\hline General budget support & 223 & 49 & 49 & 104 & 158 \\
\hline Central Government debt service obligations (excl. IMF) & -53 & -22 & -47 & -78 & -103 \\
\hline Program exchange rate (Kwacha per U.S. dollar) ${ }^{8}$ & 4,641 & 4,641 & 4,641 & 4,641 & 4,641 \\
\hline
\end{tabular}

Sources:

${ }^{1}$ The definitions of the items in the quantitative program are contained in the Technical Memorandum of Understanding (TMU)

${ }^{2}$ These targets are outside of the ECF arrangement period.

${ }^{3}$ Adjustors, including for general budget support, are defined in the TMU.

${ }^{4}$ The ceiling will be adjusted for changes in the legal reserve requirements as specified in the TMU.

${ }^{5}$ Reserves are calculated at program exchange rates.

${ }^{6}$ Continuous performance criteria and cumulative from the beginning of 2011.

${ }^{7}$ Nonconcessional loans are those having a grant element of less than 35 percent.

${ }^{8}$ This exchange rate is not a projection but a rate (fixed at the level of end-2009) that is used for the calculation of program targets, as specified in the Technical Memorandum of Understanding. 
MEFP Table 3. Zambia: Structural Benchmarks for 2010-11

\begin{tabular}{|c|c|c|c|}
\hline Measure & Timing & Macro Rationale & Status \\
\hline Approval by Cabinet of the pay policy reform & End-June 2010 & $\begin{array}{l}\text { Strengthen payroll management, and } \\
\text { increase productivity of the public } \\
\text { sector. }\end{array}$ & Met \\
\hline $\begin{array}{l}\text { Establish a Lender-of-Last Resort Framework and draft } \\
\text { legislation and procedures for a financial sector } \\
\text { contingency plan in the event of a crisis. }\end{array}$ & End-June 2010 & $\begin{array}{l}\text { Strengthen the Central Bank's crisis } \\
\text { preparedness. }\end{array}$ & $\begin{array}{l}\text { Partially Met. } \\
\text { Draft legislation } \\
\text { expected by } \\
\text { end-May } 2011\end{array}$ \\
\hline Submit to parliament the Planning and Budgeting Act. & End-June 2010 & $\begin{array}{l}\text { Strengthen public expenditure } \\
\text { management and budget execution, } \\
\text { including improving cash flow } \\
\text { management and forecasts. }\end{array}$ & $\begin{array}{l}\text { Reset to end- } \\
\text { January } 2011\end{array}$ \\
\hline $\begin{array}{l}\text { Raise the average electricity tariff in } 2010 \text { and publicly } \\
\text { announce indicative tariffs for } 2011 \text { consistent with the } \\
\text { policy to reach cost-reflective levels by } 2011 \text {. }\end{array}$ & End-June 2010 & $\begin{array}{l}\text { To ensure an efficient and } \\
\text { sustainable power supply. Solving } \\
\text { the current problems in the energy } \\
\text { sector is essential to achieving the }\end{array}$ & $\begin{array}{l}\text { Met with delay } \\
\text { (July 26, 2010) }\end{array}$ \\
\hline Prepare a review of tax administration and policy & End-September 2010 & Strenghten revenue performance & Met \\
\hline $\begin{array}{l}\text { Adoption of Treasury Single Account so as to cover } 60 \\
\text { percent of budgetary expenditures. }\end{array}$ & End-December 2010 & $\begin{array}{l}\text { Strengthen public expenditure } \\
\text { management and budget execution, } \\
\text { including improving cash flow } \\
\text { management and forecasts. }\end{array}$ & \\
\hline Submit to Cabinet a report on maize pricing policy. & End-March 2011 & $\begin{array}{l}\text { Preserve macroeconomic stability } \\
\text { and minimize disruptions to private } \\
\text { sector trading of maize. }\end{array}$ & \\
\hline
\end{tabular}




\section{Attachment II. TeChnical Memorandum of Understanding FOR the 2010-11 EXTENDED CREDIT FACILITY (ECF) ARRANGEMENT}

\section{INTRODUCTION}

1. This memorandum sets out the understandings between the Zambian authorities and the International Monetary Fund (IMF) regarding the definitions of the quantitative performance criteria and indicative targets for the program supported by the ECF arrangement, as well as the program adjusters and the related reporting requirements.

\section{Quantitative Performance Criteria And IndiCative Targets: Definitions AND DATA SOURCES}

\section{A. Net Domestic Assets (NDA) of the Bank of Zambia (BoZ)}

1. Net domestic assets (NDA) of the BoZ are defined as the monthly average (based on daily data) of reserve money (as defined below) less the monthly average of net foreign assets of the BoZ calculated at kwacha 4,640.6 per U.S. dollar for 2010 and 2011. ${ }^{1}$ Net foreign assets of the BoZ are defined as gross international reserves (defined in paragraph 9) plus any other foreign assets, minus foreign liabilities (defined in paragraph 3 ). ${ }^{2}$ The kwacha values of net foreign assets are derived from the U.S. dollar values using the program exchange rate.

2. Foreign liabilities are defined as short term (one year or less in original maturity) liabilities of the BoZ to nonresidents, plus any outstanding use of IMF credit, plus the stock of SDRs allocations to Zambia, and plus any other medium and long term foreign liabilities of BoZ.

3. Daily data on NDA, including all its components and calculation, will be reported by the BoZ weekly in electronic format and shall be consistent with the Standard Reporting Format (SRF) for monetary accounts.

\footnotetext{
${ }^{1}$ Unless otherwise defined, program exchange rates for 2010 and 2011 between the U.S. dollar and other (non-kwacha) currencies will be equal to their end-December 2009 values. For the 2010 and 2011 program, the U.S. dollar/SDR rate is 1.567; the U.S. dollar/GBP rate is 1.624, the U.S. dollar/euro rate is 1.459 , and the U.S. dollar/South Africa Rand is 0.133. All other assets (e.g. gold) would be revalued at their end-December 2009 market prices for 2010 and 2011.

${ }^{2}$ Other foreign assets include encumbered reserves and any other foreign assets of BoZ.
} 


\section{B. Reserve Money}

4. Reserve money (monthly average based on daily data) is defined as currency in circulation, plus required reserves on kwacha deposits, plus required reserves on foreign currency deposits (at the program exchange rate), plus any positive current account balance of Other depository corporations (ODC) with the BoZ, and plus deposits in the BoZ of sectors other than central government.

5. Daily data on reserve money, including its components, will be reported by the BoZ weekly in electronic format and shall be consistent with the SRF for monetary accounts.

\section{Net Domestic Financing (NDF)}

6. Net domestic financing (NDF) is defined as the Budgetary Central Government's net borrowing from the banking and nonbanking sectors. ${ }^{3}$ All government-issued securities will be recorded at cost (face value less discount). NDF will comprise:

(a) the net position of the central Government with commercial banks, including:

(i) Treasury bills; (ii) government bonds; (iii) loans and advances; less (iv) support to Meridien Bank of Zambia (MBZ); and (v) central government deposits (defined to include account balances under the authority of controlling officers); plus

(b) BoZ holdings of: (i) Treasury bills; (ii) government bonds; (iii) kwacha bridge loan (overdraft facility); less (iv) the government's deposits at the BoZ; and (v) the donor suspense account; plus (vi) the outstanding amount of the long-term non-transferable security (10-Year Mega Bond) issued against the government's indebtedness to BoZ as at end-2002; plus

(c) Nonbank holdings of: Treasury bills; and government bonds.

7. The data source for NDF will be the "Net Domestic Financing" Table produced by the Economics Department of the BoZ. The Table will be submitted on a weekly basis in electronic format, and end-month outturns will be fully reconciled with the monthly monetary survey.

\section{Gross International Reserves of the $\mathrm{BOZ}$}

8. Unless otherwise noted here, gross international reserves of the BoZ will be defined as reserve assets of the BoZ (See Table 2). Reserve assets are defined in the IMF BOP manual ( $5^{\text {th }}$ edition) and elaborated in the reserve template of the IMF's special data

\footnotetext{
${ }^{3}$ The Budgetary Central Government includes all the units identified by the budget heads listed in the Yellow Book for 2010 and listed in Table 1.
} 
dissemination standards (SDDS). They exclude, for example, foreign assets not readily available to or controlled by the monetary authorities, and foreign currency claims on Zambian residents.

9. Gross international reserves consist of: (i) monetary gold; (ii) foreign currency; (iii) unencumbered foreign-currency deposits at non-resident banks; (iv) foreign securities and deposits; and (v) SDR holdings and Zambia's reserve position with the IMF. Gross reserves exclude non-convertible currencies, any encumbered reserve assets including but not limited to reserve assets pledged, swapped or used as collateral or guarantee for third-party external liabilities, other depository corporation reserve requirements on foreign currency deposits, and the US\$25 million deposit in MBZ (in liquidation).

10. For the purpose of this target valuation will be in U.S. dollars at program exchange rates.

11. Daily data on gross international reserves, including its components, will be reported by the BoZ weekly.

\section{E. External Payment Arrears}

12. The performance criterion on the non-accumulation of new external payment arrears is continuous. Official external payment arrears are defined as unpaid debt service by the central Government and BoZ 30 days beyond the due date and/or the grace period. This definition excludes arrears on debt subject to rescheduling.

13. Data on arrears, at program exchange rates, are compiled jointly by the Ministry of Finance and National Planning (MoFNP) and BoZ and will be reported by the MoFNP on a quarterly basis.

\section{F. Official External Debt}

14. Official medium- and long-term concessional external debt is defined as all forms of official debt with original maturity of more than one year contracted or guaranteed by the central Government, BoZ, ZESCO, and Zambia Railways Limited with nonresidents having a grant element of no less than 35 percent, since the beginning of the calendar year. The grant element is the difference between the present value (PV) of debt and its nominal value, and is expressed as a percentage of the nominal value of the debt. The PV of debt at the time of its contracting is calculated by discounting the future stream of payments of debt service due on this debt. ${ }^{4}$ The discount rates used for this purpose are the currency-specific commercial

\footnotetext{
${ }^{4}$ The calculation of concessionality will take into account all aspects of the loan agreement, including maturity, grace period, payment schedule, upfront commissions, and management fees.
} 
interest reference rates (CIRRs) published by the Organization for Economic Cooperation and Development (OECD). ${ }^{5}$ For debt with a maturity of at least 15 years, the ten-year-average CIRR will be used to calculate the PV of debt and, hence, its grant element. For debt with a maturity of less than 15 years, the six-month average CIRR will be used. To both the ten-year and six-month averages, the same margins for differing repayment periods as those used by the OECD need to be added ( 0.75 percent for repayment periods of less than 15 years, 1 percent for 15 to 19 years, 1.15 percent for 20 to 29 years, and 1.25 percent for 30 years or more). Lending from the IMF will be excluded.

15. This minimum grant element applies not only to debt as defined in Point 9 of the Guidelines on Performance Criteria with Respect to External Debt in Fund Arrangements (Decision No. 6230-(79/140), as subsequently amended, including by Executive Board Decision No. 14416-(09/91), effective December 1, 2009, but also to commitments contracted or guaranteed for which value has not been received.

16. Official external nonconcessional debt is defined as the contracting or guaranteeing of debt with nonresidents other than concessional debt as defined in paragraph 15, owed or guaranteed by the central Government, BoZ, ZESCO, and Zambia Railways Limited.

17. The ceiling on contracting or guaranteeing of medium and long-term nonconcessional external debt by the central government, BoZ, ZESCO, and Zambia Railways Limited excludes: (i) nonconcessional loans stemming from the rescheduling of external debt; and (ii) central government securities issued in domestic currency, placed in the domestic primary or secondary markets, and held by non-residents.

18. Official external short-term debt is defined as the contracting or guaranteeing of debt with nonresidents with original maturity of one year or less, and includes forward commodity sales but will exclude normal trade credit for imports, incurred since the beginning of the calendar year. The term "debt" has the meaning set forth in point No. 9 of the Guidelines on Performance Criteria with Respect to External Debt (Decision No. 6230-(79/140), as subsequently amended, including by Executive Board Decision No. 14416-(09/91), effective December 1, 2009.

19. Detailed data on all new external debt (concessional and nonconcessional) contracted or guaranteed by the central government, BoZ, ZESCO, and Zambia Railways Limited will be provided by the MoFNP on a monthly basis. Information will include (i) amounts contracted or guaranteed; (ii) currencies; and (iii) terms and conditions, including interest rate, maturity, grace period, payments per year, commissions and fees, and collaterals.

\footnotetext{
${ }^{5}$ Available at http://www.oecd.org/dataoecd/21/52/39085945.xls. Where the CIRR is not available, the SDR rate shall be used.
} 


\section{G. Domestic Arrears of Central Government}

20. Domestic arrears are defined as: (i) any bill that has been received by a spending ministry from a supplier for goods and services delivered (and verified) and for which payment has not been made within 30 days after the due date of payments; (ii) wage, salary and any other payment to government employees, including pension contributions and all forms of housing allowances, that were due to be paid in a given month but remained unpaid on the $15^{\text {th }}$ of the following month; and (iii) interest or principal obligations which remain unpaid 30 days after the due date of payment.

21. Information regarding domestic arrears will be compiled through audits of the accounts of spending Ministries and agencies, conducted by the Internal Audit division of the MoFNP. The audits will be completed and data submitted to IMF staff by the Secretary of the Treasury within six weeks of the end of each quarter.

\section{H. Floor on Social Spending}

22. Social spending is defined as central government domestically financed expenditure on health and education as listed in the 2010 and 2011 Yellow Book under the functional classification. The corresponding indicative target sets the minimum spending on these sectors combined.

\section{ADJUSTERS}

23. The quantitative performance criteria specified under the program are subject to the following adjusters:

\section{General budget support (GBS) net of debt service ${ }^{6}$}

(i) The ceilings on NDA and NDF will be adjusted downward (upward) by the full amount of the excess (shortfall) in GBS net of debt service relative to the programmed levels specified in Table 1 of the MEFP. ${ }^{7,8}$

(a) The total adjustment for shortfalls will be limited to US\$40 million for January-June 2010 and US\$60 million for January-December 2010.

\footnotetext{
${ }^{6}$ General budget support consists of grants and loans received by the central government for financing its overall policy and budget priorities following Zambian budget procedures.

${ }^{7}$ For the purpose of adjusting the NDA ceiling, external disbursements will be treated as if they were received the first day of the month. The targeted NDA will be increased by the amount of the disbursement divided by the number of business days in the month multiplied by the number of business days from the beginning of the month to the day prior to the disbursement.

${ }^{8}$ For purpose of adjusting the NDF ceiling, the cumulative excess/shortfall will be converted to kwacha value using the program exchange rate.
} 
(ii) The floors on GIR will be adjusted upward (downward) by the full amount of the excess (shortfall) in GBS net of debt service relative to the programmed levels (Table 1 of the MEFP).

\section{Change in reserve requirements}

(iv) The ceiling on NDA will be adjusted downward/upward to reflect decreases/increases in the legal reserve requirements on deposits in commercial banks. The adjuster will be calculated as the percent change in the reserve requirement multiplied by the actual amount of required reserves (kwacha and foreign-currency denominated) at the end of the previous calendar month.

\section{IMF disbursement}

(v) The floors on GIR will be adjusted upward (downward) for any excess (shortfall) in the disbursements from the IMF (U.S. dollar value at the program exchange rate) relative to the programmed levels.

\section{BoZ short-term debt}

(vi) The floor on GIR will be adjusted upward for any increase in the U.S. dollar value at the program exchange rate of BoZ short-term debt, (see definition of short-term debt above).

\section{REPORTING REQUIREMENT}

24. To facilitate monitoring of the program, the information listed in Table 2 below will be reported to the IMF within the timeframe indicated. These data, and any other information needed for monitoring of adherence to program targets, will be provided electronically by email to AFRZMB@IMF.ORG. 
Table 1. Administrative units comprising the Budgetary Central Government

Office of the President

Office of the Vice President

National Assembly

Gender in Development Division

Electoral Commission

Public Service Commission - Office of the President

Office of the Auditor General

Cabinet Office - Office of the President

Teaching Service Commission - Office of the President

Police and Prisons Service Commission

Zambia Police - Ministry of Home Affairs

Commission for Investigations - Office of the President

Ministry of Energy and Water Development

Ministry of Mines and Mineral Development

Ministry of Home Affairs

Ministry of Foreign Affairs

Judiciary

Loans and Investments - Local Government and Housing

Loans and Investments

Ministry of Information and Broadcasting Services

Public Service Management Division

Ministry of Local Government and Housing

Ministry of Justice

Ministry of Commerce, Trade and Industry

Human Rights Commission
Ministry of Finance and National Planning

Ministry of Labour and Social Security

Ministry of Community Development and Social Services

Ministry of Health

Ministry of Communications and Transport

Ministry of Works and Supply

Ministry of Science, Technology and Vocational Training

Ministry of Tourism, Environment and Natural Resources

Ministry of Sport, Youth and Child Development

Ministry of Defence

Zambia Security Intelligence Services - Office of the President

Ministry of Education

Ministry of Lands

Anti-Corruption Commission

Ministry of Livestock, and Fisheries Development

Ministry of Agriculture and Cooperatives

Office of the President - Lusaka Province

Office of the President - Copperbelt Province

Office of the President - Central Province

Office of the President - Northern Province

Office of the President - Western Province

Office of the President - Eastern Province

Office of the President - Luapula Province

Office of the President - North-Western Province

Office of the President - Southern Province 
Table 2: Reporting Requirements

\begin{tabular}{|c|c|c|c|c|c|}
\hline \multirow[b]{2}{*}{ Data description } & \multirow{2}{*}{$\begin{array}{l}\text { Data } \\
\text { Freq. }\end{array}$} & \multicolumn{2}{|c|}{ Reporting } & \multirow[b]{2}{*}{ Date } & \multirow[b]{2}{*}{ Mode } \\
\hline & & Agency & Freq. & & \\
\hline \multicolumn{6}{|l|}{ Monetary and financial sector } \\
\hline Reserve money and its components (NDA and NFA) at current and program exchange rate & D & Boz & W & T5 & $\mathrm{E}$ \\
\hline Excess reserves & D & Boz & M & T5 & $\mathrm{E}$ \\
\hline Overnight interbank rates & D & Boz & W & T5 & $\mathrm{E}$ \\
\hline Treasury bill and BoZ bill auction results & W & Boz & W & T5 & $\mathrm{E}$ \\
\hline Interest rates & M & Boz & M & T15 & $\mathrm{E}$ \\
\hline $\begin{array}{l}\text { Holdings of government and BoZ securities by maturity and type of investors (local commercial banks, } \\
\text { nonbanks, and foreigners) }\end{array}$ & M & Boz & M & T15 & E \\
\hline Monetary survey (and the BoZ, and Other Depository Corporations surveys) & M & Boz & M & T15 & $\mathrm{E}$ \\
\hline Commercial bank lending. Credit to the economy by sector and type of institution & M & BoZ & M & T15 & $\mathrm{E}$ \\
\hline Financial soundness indicators by banks & M & BoZ & M & T15 & $\mathrm{E}$ \\
\hline \multicolumn{6}{|l|}{ External sector } \\
\hline Exchange rates & D & Boz & W & T5 & $\mathrm{E}$ \\
\hline Gross international reserves, and foreign exchange purchases and sales & D & Boz & W & T5 & $\mathrm{E}$ \\
\hline Copper prices & D & BoZ/CSO & W & T5 & $\mathrm{E}$ \\
\hline BoZ foreign exchange cash flow & M & Boz & M & $\mathrm{T} 10$ & $\mathrm{E}$ \\
\hline Import and export data & M & cso & M & T15 & $\mathrm{E}$ \\
\hline Balance of payments & Q & Boz & Q & T30 & $\mathrm{E}$ \\
\hline Copper production and exports (quantities, prices and US dollar value) & M & $\mathrm{MoF}$ & M & T15 & $\mathrm{E}$ \\
\hline Foreign direct investment (actuals and pledges) & M & MoF/ZDA & M & T15 & $\mathrm{E}$ \\
\hline \multicolumn{6}{|l|}{ Fiscal } \\
\hline Net Domestic Financing & D & Boz & W & T5 & $\mathrm{E}$ \\
\hline Fiscal table including revenue, expenditure, and financing. & M & MOF & M & T30 & $\mathrm{E}$ \\
\hline \multicolumn{6}{|l|}{ Real sector } \\
\hline Consumer price index and monthly statistical bulletin & M & cso & M & T15 & $\mathrm{E}$ \\
\hline National accounts & A & CSO & $\mathrm{BA}$ & $\begin{array}{l}\text { Mar. 15; } \\
\text { Sep. } 15\end{array}$ & $\mathrm{E}$ \\
\hline \multicolumn{6}{|l|}{ Program monitoring } \\
\hline Report on IMF program performance & Q & MOF & Q & T15 & $\mathrm{E}$ \\
\hline Stock of domestic and external payment arrears & Q & AuG & Q & T15 & $\mathrm{E}$ \\
\hline Central government domestic borrowing & Q & Boz & M & T15 & $\mathrm{E}$ \\
\hline New external loans contracted or guaranteed by the central government BoZ, ZESCO, ZAMTEL, and & & & & & \\
\hline Zambia Railways Limited or any other agency on their behalf ${ }^{1}$ & Q & MOF & Q & T30 & $\mathrm{E}$ \\
\hline
\end{tabular}

D-Daily, W-Weekly, M-Monthly, Q-Quarterly, BA-Bi-annual A-Annual; Tx: $x$ days after the date of the last observation; E-email, H-Hard copy

1 Detailed information on the amounts, currencies, terms, conditions, and purpose (to finance electricity and road projects listed on the quantitative performance criteria table, or other purposes). 


\title{
APPENDIX II. ZAMBIA-JOINT IMF/WORLD BANK DEBT SUSTAINABILITY ANALYSIS 2010 UNDER THE DEBT SUSTAINABILITY FRAMEWORK FOR LOW INCOME COUNTRIES
}

\author{
Prepared by the staffs of the International Monetary Fund and \\ the International Development Association
}
Approved by Michael Atingi Ego and James Roaf (IMF) and Jan Walliser and Sudarshan Gooptu (IDA)

November 24, 2010

\begin{abstract}
Based on the Joint Fund-Bank Debt Sustainability Framework for Low-income Countries (LIC DSA), Zambia's risk of debt distress remains low as all debt indicators stay below the indicative policy thresholds throughout the projection period (2010-2030). The public DSA suggests that Zambia's overall public sector debt dynamics are sustainable in light of the current size and the evolution of the domestic debt stock. However, alternative scenarios underscore the need for careful debt management in the face of an expected rise in nonconcessional borrowing. Sound macroeconomic policies, including a prudent fiscal position, and strong debt management and project appraisal capacity are needed to maintain debt sustainability, while allowing for non-concessional external borrowing for growth-critical infrastructure investment. The authorities agree with staffs' assessment, highlighting the importance of sound macroeconomic policies and enhanced capacity for debt management and project appraisal. ${ }^{1}$
\end{abstract}

\section{BACKGROUND}

1. Zambia is at an important juncture where some of the large-scale projects, including energy and roads, are starting to be financed through non-concessional external borrowing. ${ }^{2}$ Zambia's stock of external public debt remains relatively low at 12.4 percent of GPD in 2009, although it has increased slightly since the debt cancellation under the HIPC Initiative and MDRI. ${ }^{3,4}$ Most of the public external debt is multilateral (see the table below) and contracted with concessional terms, but the share of non-concessional loans is expected to

\footnotetext{
${ }^{1}$ The DSA has been produced jointly by Bank and Fund staffs using debt data provided by the authorities.

${ }^{2}$ For example, a non-concessional loan was contracted in 2009 to finance the Kariba North Bank extension project, one of the three major hydropower projects. The development of the Kafue Gorge Lower project is also expected to start in mid-2011 through a public-private partnership.

${ }^{3}$ Zambia's stock of external debt declined substantially from about 86 percent of GDP in 2005 to around 9 percent in 2006. The Government of Zambia continues discussions with the Paris and non-Paris Club members on remaining debt cancellation under the HIPC framework.

${ }^{4}$ The 2009 DSA projected the 2009 debt stock to be US $\$ 1,658$ million. The actual 2009 debt stock was slightly lower than projected partly owing to shortfalls in the loan disbursement.
} 
increase in $2010 / 2011$ and beyond as the authorities plan to use non-concessional sources to boost the public investment program.

Zambia: External Public and Publicly Guaranteed Debt

\begin{tabular}{lrr}
\hline & Million USD & \% of GDP 1/ \\
& 2009 & 2009 \\
\hline PPG debt & 1,587 & 12.4 \\
Multilateral & 1,145 & 8.9 \\
IMF & 348 & 2.7 \\
Other & 797 & 6.2 \\
Bilateral official & 99 & 0.8 \\
Paris Club & 90 & 0.7 \\
Other & 9 & 0.1 \\
Suppliers and other & 133 & 1.0 \\
Parastatal & 210 & 1.6 \\
Memo item & & \\
GDP USD million & 12,805 & \\
\hline
\end{tabular}

Sources: Ministry of Finance and National Planning; and staff estimates Note: 1/ Figures in percent of GDP may differ in the DSA template due to exchange rates.

2. Zambia's public sector debt also remains low at 24.9 percent of GDP at end 2009. ${ }^{5}$ As for the composition, the share of domestic debt is about 57 percent. Treasury bills and bonds comprise 90 percent of domestic debt.

\section{Zambia: Structure of Public Sector Debt}

\begin{tabular}{lc}
\hline Unit: percent & 2009 \\
\hline Public Debt & 100.0 \\
External debt & 43.2 \\
Domestic debt & 56.8 \\
\hline Sources: Ministry of Finance and National Planning \\
\multicolumn{2}{c}{ and staff estimates }
\end{tabular}

3. This DSA, which is fully consistent with the macroeconomic framework (Box 1), updates the 2009 DSA by incorporating important recent developments in Zambia. ${ }^{6}$ Most notably, the current DSA departs from the assumption made in the 2009 DSA that nonconcessional external borrowing will moderate in the long run. Rather, this DSA assumes that a sizeable amount of non-concessional borrowing will continue even beyond the medium

\footnotetext{
${ }^{5}$ With debt relief in 2006 and relatively low budget deficit over the last few years, the domestic financing needs have been lower.

${ }^{6}$ See Appendix II in "Zambia: 2009 Article IV Consultation, Third Review Under the Three-Year Arrangement Under the Poverty Reduction and Growth Facility, and request for Modification of Performance Criteria" IMF Country Report No.10.17, January 2010.
} 
term in light of large infrastructure investment needs. ${ }^{7}$ Declining donors' support as a share of GDP also calls for a careful look at the growing needs for alternative sources to finance infrastructure investment and their possible impact on debt sustainability.

\section{UNDERLYING DSA ASSUMPTIONS}

4. The Zambia's strong economic performance continues in 2010. GDP is projected to expand by 6.6 percent, supported by vigorous mining exports. Inflation declined to 7.3 percent in October 2010, mainly due to the favorable maize crop. The current account deficit is also expected to narrow, and international reserves have remained solid. The baseline scenario assumes prudent economic policies to foster stable macroeconomic conditions. Inflation is expected to remain in single-digits; real economic growth will continue to be strong supported by commodity exports, infrastructure investment, and expanded electricity generation capacity (Box 1).

5. The baseline scenario also assumes new public external borrowing in the order of US\$3.3 billion in 2010-2016 (equivalent to US\$ 470 million per year), of which US $\$ 1.8$ billion is assumed to be on non-concessional terms (54 percent of total loan disbursements). ${ }^{8}$ Approximately the same annual amount of disbursements is assumed for the outer years (about US\$521 million on average per year) with a share of non-concessional financing remaining at around 54 percent. The average grant element of new borrowing thus declines from 30 percent in 2010 to about 16 percent in 2011-16, remaining at a similar level for the rest of the period.

\footnotetext{
${ }^{7}$ A recent World Bank study assesses that Zambia needs to spend an average of $\$ 1.6$ billion a year over the next decade to develop its infrastructure. See "Zambia's Infrastructure: A Continental Perspective," World Bank, March 2010.

${ }^{8}$ The current Extended Credit Facility program allows for non-zero limits on non-concessional external borrowing: The 2009 program included up to US $\$ 400$ million of non-concessional loans for electricity projects, and under this limit, US\$316 million was contracted in 2009 . The 2010 program includes US\$600 million of non-concessional debt ceiling for energy and road projects. These limits are on a contracted basis while the DSA accounts for the amount disbursed which may not necessarily be the same as the amount contracted in a given year.
} 


\section{Box 1: Baseline Macroeconomic Assumptions}

Economic growth: Real GDP growth is assumed to pick up to about 7 percent in the medium term supported by mining activity (copper), large infrastructure investment and increased electricity generation capacity. In the long run, the mining sector remains to be important, but economic diversification is also assumed in other areas such as electricity generation, agriculture, and tourism, and the economy is expected to grow at around 6 percent annually.

Inflation: The current objective of monetary policy is to reduce inflation to 8 percent by end-2010 and maintain single digits thereafter. Prudent monetary and fiscal policies are expected to reduce annual inflation to around 5 percent in the medium term.

External sector: Long-term mining output is expected to grow in line with real GDP, and the copper price growth is assumed to stabilize at 3.5 percent in the long run. While copper, whose exports have been particularly strong in 2010, will remain Zambia's most important export, its share in total exports value is expected to decline gradually over time in the medium term and stabilize in the long term (about 65 percent of total exports by 2030 against 76 percent in 2009). Foreign direct investment (FDI) is expected to rise in the medium term, especially in energy and mining sectors, but stabilize in the long run at around 5 percent of GDP. The current account deficit is assumed to worsen to about 6 percent of GDP in the medium term as import-intensive infrastructure investment commences. In the long run, the current account deficit is expected to narrow to around 4 percent of GDP as mining related income outflows stabilize and exports rise as the economy become more diversified.

Government revenue and expenditure: Fiscal policy will be geared at creating space for spending needs to enhance the economic diversification of Zambia. To this end, higher revenue will be mobilized through improvements in tax administration, and new tax policy measures that would broaden tax base. As a result, revenues would rise gradually from 17.8 percent of GDP in 2010 to 23 percent by 2030. Expenditures would stay at an elevated level in the near term mainly due to the growth-critical infrastructure investment, but are expected to remain at about 24 percent of GDP on average over the entire DSA period, with current spending contained.

Government financing: External financing is 0.7 percent of GDP in 2010, expected to increase to about 3 percent of GDP in the near term to finance capital spending with less concessional terms. However, external financing is expected to decline to below 1 percent of GDP over the long term. Domestic financing is 2.6 percent of GDP in 2010 but expected to stabilize at around 0.5 percent of GDP over the rest of the DSA period. A substantial reduction in grant financing is also expected. 


\section{EXTernal DebT Sustainability}

\section{Baseline scenario}

6. External debt burden indicators rise in the medium term, but they are expected to remain well below the indicative policy thresholds over the projection period (Figure 1 and Table 1). ${ }^{9}$ The stock of external public and publicly guaranteed (PPG) debt is expected to rise to around 15 percent of GDP by 2016 but gradually decline thereafter. The present value (PV) of PPG debt to GDP is in the 7 to 14 percent range through 2010-2015, well below the 40 percent threshold, and declines thereafter. The PV of debt to exports ratio increases to 44 percent in 2015 , and falls gradually thereafter, remaining well below the threshold of 150 percent. The PV of PPG debt to revenue increases from 41 percent in 2010 to about 70 percent in 2014, falling thereafter, but it is well below the threshold of 250 percent. The debt service to export ratio increases from 1.6 percent in 2010 to 2.8 percent by 2019 , but it is also well below the 20 percent threshold.

\section{Stress test}

7. The standard sensitivity analysis points to a low risk of debt distress, but the historical scenario highlights potential risks associated with the expected higher level of external borrowing (Table 3). The historical average scenario may not represent a plausible benchmark for Zambia given the significant progress made in the macroeconomic management over the recent years. However, it can also be interpreted as a severe shock scenario where unsound macro policies result in large external imbalances. Under the historical scenario, the PV of debt to GDP ratio approaches the threshold level of 40 percent in 2023, falling back thereafter. This result is mainly driven by the large non-interest current account deficit (10-year historical average of -10.2 percent of GDP), which reflects the poor performance of the Zambian economy in the early 2000s. Similar rising trajectories are observed for other indicators, but they remain below the thresholds. The scenario based on historical averages thus clearly underscores the criticality of strong economic performance supported by sound macroeconomic policies to maintain external debt sustainability in Zambia while allowing for increased non-concessional borrowing.

8. The most extreme stress for the PV of debt-to-GDP ratio and debt-to-revenue ratio is a one-time 30 percent nominal depreciation relative to the baseline in $2011 .{ }^{10}$ As a result of this shock, the ratios increase by 33 percent relative to the baseline 2014-15, but remain far below their respective threshold and decline thereafter. The most extreme shock for the PV

9 The World Bank's Country Policy and Institutions Assessment (CPIA) ranks Zambia as a medium performer (the average 2007-09 CPIA is 3.47). Thus, the external debt burden thresholds for Zambia are (i) a PV of debtto-GDP at: 40 percent; (ii) a PV of debt-to-exports at: 150 percent; (iii) a PV of debt-to-revenue at: 250 percent; (iv) a debt service-to-exports at: 20 percent: and (v) a debt service-to-revenue at: 30 percent.

${ }^{10}$ The most extreme test is defined as the test that yields the highest ratio in 2020. 
of debt-to-exports ratio is contracting new public sector loans on less favorable terms in 2010-2030 (i.e. a higher interest rate by 2 percentage points than the baseline). Liquidity indicators remain below their respective thresholds under all tests as well. These results demonstrate that Zambia's risk of debt distress is low even under difficult circumstances with various shocks.

\section{Public Debt Sustainability}

\section{Baseline scenario}

9. Zambia's public debt rises slightly in the medium term but declines gradually over time. PV of public debt to GDP ratio increases from 24 percent in 2010 to 27 percent by 2014 and comes down thereafter to about 14 percent by 2030 . Thus, public debt is rather modest and manageable.

\section{Stress test}

10. The standard sensitivity analysis shows that Zambia's public debt is broadly resilient to shocks. Most of the resulting debt indicators under the various standard shocks deviate marginally from those under the baseline and decline over time. However, the results under the fixed primary balance scenario (fixing the primary balance unchanged from 2010) underscore the need for fiscal consolidation in the long run to maintain public debt sustainability (Table 4). Under this scenario, PV of debt-to-GDP ratio and PV of debt-torevenue ratio keep rising over time, suggesting that the primary deficit in 2010 (1.6 percent of GDP) is not sufficiently small enough to stabilize these indicators. Smaller primary deficit (or even surplus) would be needed to reverse this trend.

\section{DebT Distress Classification ANd Conclusions}

11. Staffs recommend that Zambia should be considered at low risk of debt distress based on the results of the external and public DSA. The external debt indicators remain well below their thresholds in the baseline scenario and bound tests. The historical average scenario, however, underlines the importance of sound macroeconomic management to maintain external debt sustainability. The public DSA also suggests that Zambia's overall public sector debt dynamics are sustainable in light of the current size and the evolution of the domestic debt stock in the baseline scenario. On the other hand, the fixed primary balance scenario demonstrates the need for an improved fiscal position in the long run. Finally, in addition to sound macroeconomic policies, strengthening debt management and developing

project appraisal capacity are needed in order to maintain debt sustainability in the face of an expected rise in non-concessional borrowing in order to capture the expected growth dividends of such investment. In this regard, the authorities are taking measures to enhance its debt management capacity, including re-organizing the debt management offices in 2011, in line with international best practices. 


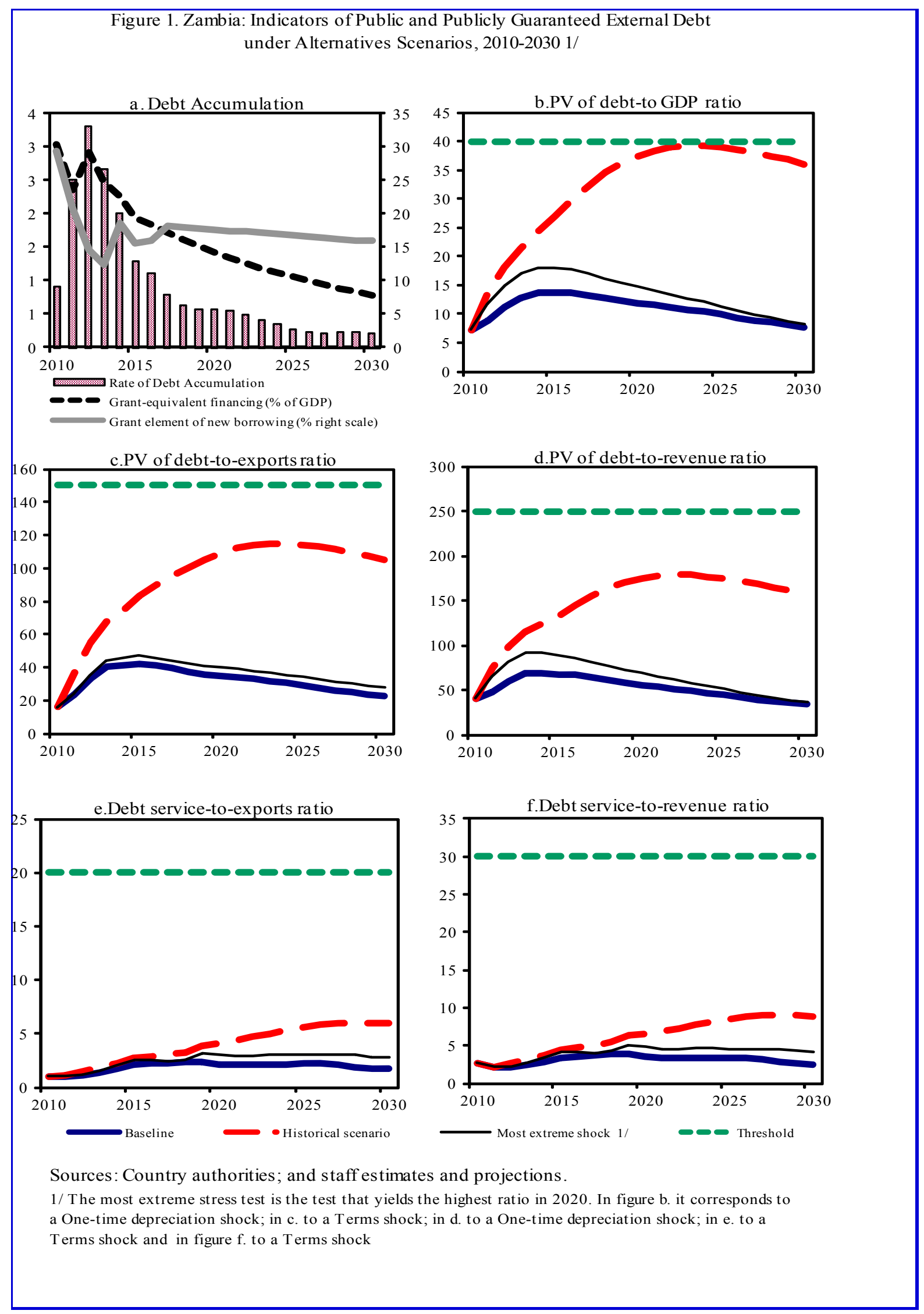


Figure 2.Zambia: Indicators of Public Debt Under Alternative Scenarios, 2010-2030 1/
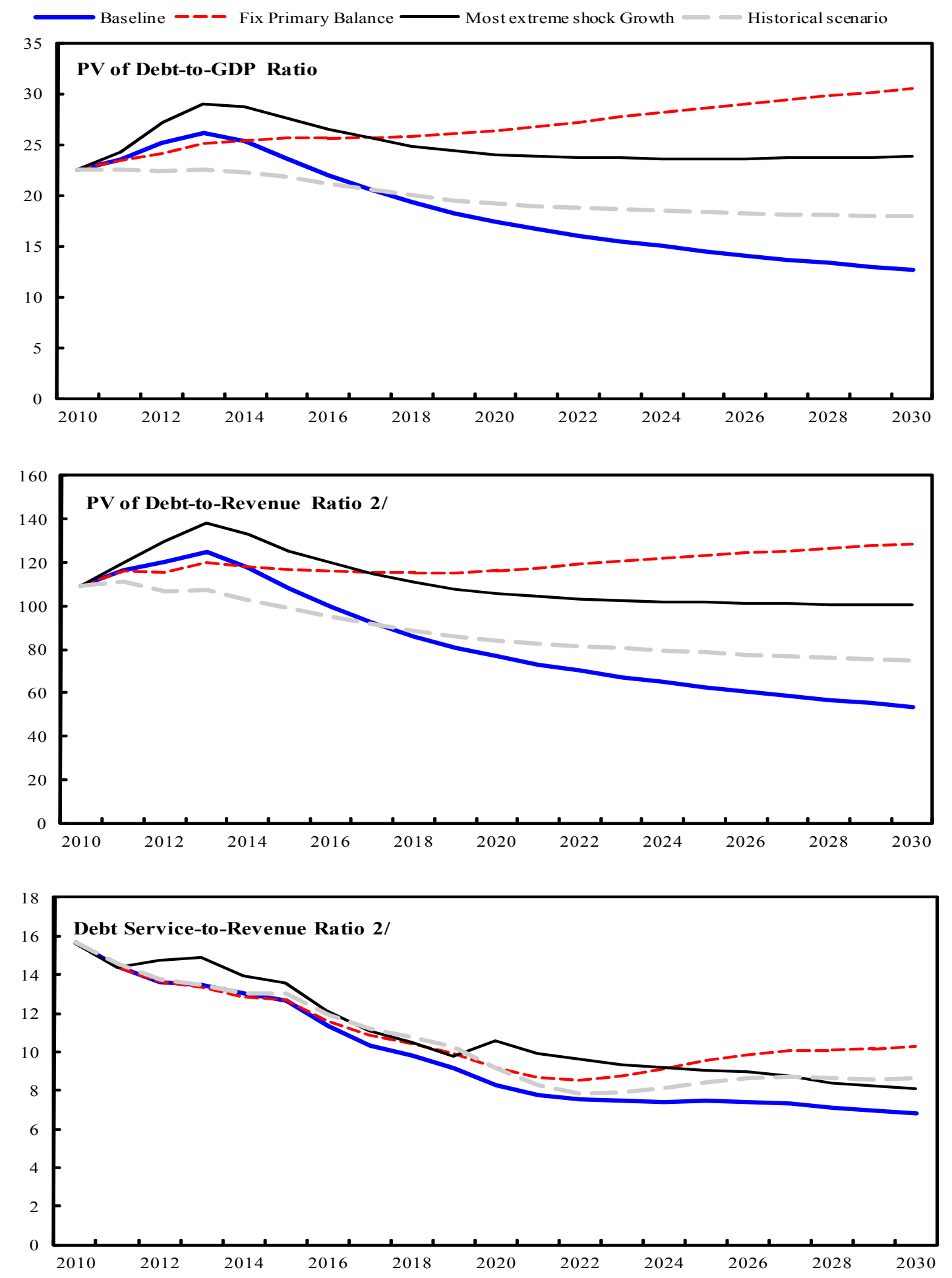

Sources: Country authorities; and staff estimates and projections.

1/ The most extreme stress test is the test that yields the highest ratio in 2020 .

2/ Revenues are defined inclusive of grants. 
Table 1.: External Debt Sus tainability Frame work, Base line Scenario, 2007-2030 1/

(Percent of GDP, unless otherwise indicated)

\begin{tabular}{|c|c|c|c|c|c|c|c|c|c|c|c|c|c|c|c|}
\hline & \multicolumn{3}{|c|}{ Actual } & \multirow{2}{*}{$\begin{array}{l}\text { Historical } \\
\text { Average 6/ }\end{array}$} & \multirow{2}{*}{$\begin{array}{l}0 \text { Standard } \\
0 \text { Jeviation 6/ }\end{array}$} & \multicolumn{6}{|c|}{ Projections } & \multirow{2}{*}{$\begin{array}{c}2010-2015 \\
\text { Average }\end{array}$} & \multirow[b]{2}{*}{2020} & \multirow[b]{2}{*}{2030} & \multirow[b]{2}{*}{$\begin{array}{c}2016-2030 \\
\text { Average }\end{array}$} \\
\hline & 2007 & 2008 & 2009 & & & 2010 & 2011 & 2012 & 2013 & 2014 & 2015 & & & & \\
\hline External debt (nominal) 1/ & 9.4 & 11.5 & 12.0 & & & 10.7 & 12.0 & 14.0 & 15.3 & 16.1 & 16.1 & & 14.0 & 9.2 & \\
\hline of which public and publicly guaranteed (PPG) & 9.2 & 11.0 & 11.4 & & & 10.2 & 11.5 & 13.6 & 14.9 & 15.6 & 15.6 & & 13.6 & 8.8 & \\
\hline Change in external debt & 0.6 & 2.1 & 0.4 & & & -1.3 & 1.3 & 2.1 & 1.3 & 0.7 & 0.0 & & -0.4 & -0.4 & \\
\hline Identified net debt-creating flows & -5.4 & -1.3 & -0.6 & & & -5.3 & -2.3 & -0.3 & -0.4 & -1.1 & -1.9 & & -2.5 & -1.1 & \\
\hline Non-interest current account deficit & 6.5 & 7.0 & 3.0 & 10.2 & 6.6 & 1.4 & 3.4 & 6.2 & 6.1 & 5.7 & 5.5 & & 3.7 & 3.3 & 3.6 \\
\hline Deficit in balance of goods and services & -2.2 & 1.4 & -3.4 & & & -9.3 & -1.9 & 2.2 & 2.9 & 2.5 & 2.5 & & 2.1 & 3.1 & \\
\hline Exports & 41.4 & 35.8 & 35.6 & & & 45.2 & 37.8 & 33.1 & 31.7 & 32.9 & 32.3 & & 34.2 & 34.3 & \\
\hline Imports & 39.2 & 37.2 & 32.2 & & & 35.9 & 35.9 & 35.3 & 34.6 & 35.4 & 34.7 & & 36.3 & 37.4 & \\
\hline Net current transfers (negative $=$ inflow) & -4.6 & -3.8 & -4.0 & -4.4 & 1.2 & -2.8 & -2.2 & -2.3 & -2.2 & -2.0 & -1.8 & & -1.3 & -0.7 & -1.1 \\
\hline of which official & -2.6 & -2.2 & -2.4 & . & . & -1.5 & -0.9 & -1.1 & -1.0 & -0.9 & -0.9 & & -0.6 & -0.3 & ... \\
\hline Other current account flows (negative $=$ net inflow) & 13.3 & 9.4 & 10.5 & & & 13.5 & 7.5 & 6.4 & 5.4 & 5.2 & 4.8 & & 2.8 & 0.9 & \\
\hline Net FDI (negative = inflow) & -11.5 & -6.4 & -5.5 & -6.1 & 2.7 & -6.3 & -5.2 & -5.8 & -5.9 & -6.1 & -6.7 & & -5.7 & -4.0 & -5.3 \\
\hline Endogenous debt dynamics 2/ & -0.4 & -1.9 & 1.9 & & & -0.4 & -0.5 & -0.7 & -0.7 & -0.7 & -0.7 & & -0.5 & -0.3 & \\
\hline Contribution from nominal interest rate & 0.1 & 0.2 & 0.2 & & & 0.2 & 0.1 & 0.1 & 0.2 & 0.3 & 0.4 & & 0.4 & 0.2 & \\
\hline Contribution from real GDP growth & -0.5 & -0.4 & -0.8 & & & -0.6 & -0.6 & -0.7 & -0.9 & -1.0 & -1.1 & & -0.9 & -0.5 & \\
\hline Contribution from price and exchange rate changes & 0.0 & -1.6 & 2.5 & & & & & & & & & & & & \\
\hline Residual (3-4) 3/ & 6.0 & 3.4 & 1.0 & & & 4.0 & 3.5 & 2.4 & 1.7 & 1.8 & 1.9 & & 2.1 & 0.6 & \\
\hline of which exceptional financing & 0.0 & 0.0 & 0.0 & & & 0.0 & 0.0 & 0.0 & 0.0 & 0.0 & 0.0 & & 0.0 & 0.0 & \\
\hline PV of external debt 4/ & & $\ldots$ & 8.3 & & & 7.8 & 9.2 & 11.5 & 13.2 & 14.0 & 14.1 & & 12.4 & 8.1 & \\
\hline percent of exports & $\cdots$ & $\ldots$ & 23.4 & & & 17.2 & 24.3 & 34.8 & 41.6 & 42.6 & 43.7 & & 36.1 & 23.6 & \\
\hline PV of PPG external debt & ... & $\ldots$ & 7.8 & & & 7.3 & 8.8 & 11.1 & 12.7 & 13.6 & 13.7 & & 11.9 & 7.8 & \\
\hline percent of exports & ... & $\ldots$ & 21.9 & & & 16.1 & 23.2 & 33.5 & 40.2 & 41.3 & 42.4 & & 34.9 & 22.6 & \\
\hline percent of government revenues & ... & $\ldots$ & 48.8 & & & 40.8 & 47.7 & 60.1 & 68.1 & 69.2 & 67.7 & & 55.8 & 33.7 & \\
\hline Debt service-to-exports ratio (in percent) & 1.4 & 1.9 & 2.0 & & & 1.6 & 1.5 & 1.7 & 1.9 & 2.2 & 2.6 & & 2.6 & 2.1 & \\
\hline PPG debt service-to-exports ratio (in percent) & 1.2 & 1.2 & 1.2 & & & 1.1 & 1.0 & 1.2 & 1.4 & 1.7 & 2.1 & & 2.2 & 1.7 & \\
\hline PPG debt service-to-revenue ratio (in percent) & 2.8 & 2.3 & 2.7 & & & 2.7 & 2.2 & 2.1 & 2.4 & 2.9 & 3.4 & & 3.5 & 2.5 & \\
\hline Total gross financing need (Billions of U.S. dollars) & -0.5 & 0.2 & -0.2 & & & -0.7 & -0.2 & 0.2 & 0.2 & 0.1 & -0.1 & & -0.5 & 0.0 & \\
\hline Non-interest current account deficit that stabilizes debt ratio & 5.8 & 4.9 & 2.6 & & & 2.6 & 2.1 & 4.1 & 4.9 & 5.0 & 5.4 & & 4.1 & 3.7 & \\
\hline \multicolumn{16}{|l|}{ Key macroeconomic ass umptions } \\
\hline Real GDP growth (in percent) & 6.2 & 5.7 & 6.3 & 5.3 & 1.0 & 6.6 & 6.4 & 6.7 & 6.8 & 7.3 & 7.4 & 6.9 & 6.5 & 6.0 & 6.3 \\
\hline GDP deflator in US dollar terms (change in percent) & -0.2 & 20.6 & -18.1 & 10.5 & 16.8 & 15.7 & 10.5 & 2.1 & 1.9 & 2.5 & 2.6 & 5.9 & 3.0 & 3.0 & 3.0 \\
\hline Effective interest rate (percent) $5 /$ & 0.9 & 2.1 & 1.6 & 1.4 & 0.6 & 2.3 & 1.4 & 0.6 & 1.3 & 2.4 & 2.6 & 1.8 & 2.9 & 2.5 & 2.6 \\
\hline Growth of exports of G\&S (US dollar terms, in percent) & 17.0 & 9.9 & -13.3 & 20.8 & 26.4 & 56.7 & -1.7 & -4.4 & 4.2 & 14.1 & 8.1 & 12.8 & 9.5 & 9.1 & 10.0 \\
\hline Growth of imports of G\&S (US dollar terms, in percent) & 40.4 & 20.9 & -24.7 & 14.9 & 17.9 & 37.8 & 17.6 & 7.2 & 6.8 & 12.4 & 8.1 & 15.0 & 10.3 & 9.5 & 10.1 \\
\hline Grant element of new public sector borrowing (in percent) & & & & $\ldots$ & $\ldots$ & 29.5 & 20.7 & 14.7 & 12.5 & 18.6 & 15.6 & 18.6 & 17.7 & 15.9 & 17.0 \\
\hline Government revenues (excluding grants, in percent of GDP) & 18.4 & 18.6 & 16.0 & & & 17.8 & 18.4 & 18.5 & 18.7 & 19.6 & 20.2 & & 21.4 & 23.0 & 21.9 \\
\hline Aid flows (in Billions of US dollars) $7 /$ & 0.7 & 0.8 & 0.5 & & & 0.5 & 0.4 & 0.6 & 0.5 & 0.5 & 0.5 & & 0.6 & 0.8 & \\
\hline of which Grants & 0.5 & 0.6 & 0.5 & & & 0.4 & 0.3 & 0.5 & 0.5 & 0.4 & 0.5 & & 0.5 & 0.7 & \\
\hline of which Concessional loans & 0.2 & 0.2 & 0.0 & & & 0.0 & 0.1 & 0.1 & 0.0 & 0.0 & 0.0 & & 0.0 & 0.0 & \\
\hline Grant-equivalent financing (in percent of GDP) 8/ & $\ldots$ & $\ldots$ & $\ldots$ & & & 3.0 & 2.4 & 2.9 & 2.5 & 2.3 & 1.9 & & 1.4 & 0.8 & 1.2 \\
\hline Grant-equivalent financing (in percent of external financing) $8 /$ & $\ldots$ & $\ldots$ & $\ldots$ & & & 82.2 & 53.7 & 50.3 & 52.0 & 56.3 & 58.5 & & 62.4 & 59.4 & 61.2 \\
\hline \multicolumn{16}{|l|}{ Memorandum items: } \\
\hline (Billions of US $\mathrm{c}$ & 11.5 & 14.7 & 12.8 & & & 15.8 & 18.6 & 20.3 & 22.1 & 24.3 & 26.7 & & 43.1 & 105.1 & \\
\hline Nominal dollar GDP growth & 6.0 & 27.4 & -12.9 & & & 23.4 & 17.6 & 9.0 & 8.9 & 10.0 & 10.1 & 13.2 & 9.7 & 9.3 & 9.6 \\
\hline PV of PPG external debt (in Billions of US dollars) & & & 1.1 & & & 1.2 & 1.6 & 2.2 & 2.8 & 3.2 & 3.5 & & 4.7 & 6.6 & \\
\hline (PVt-PVt-1)/GDPt-1 (in percent) & & & & & & 0.9 & 2.5 & 3.3 & 2.7 & 2.0 & 1.3 & 2.1 & 0.6 & 0.2 & 0.5 \\
\hline Gross workers' remittances (Billions of US dollars) & 0.1 & 0.1 & 0.0 & & & 0.0 & 0.0 & 0.0 & 0.1 & 0.1 & 0.1 & & 0.1 & 0.2 & \\
\hline PV of PPG external debt (in percent of GDP + remittances) & & $\ldots$ & 7.8 & & & 7.3 & 8.7 & 11.1 & 12.7 & 13.5 & 13.6 & & 11.9 & 7.7 & \\
\hline PV of PPG external debt (in percent of exports + remittances) & & $\ldots$ & 21.7 & & & 16.0 & 23.0 & 33.2 & 39.9 & 41.0 & 42.1 & & 34.7 & 22.5 & \\
\hline Debt service of PPG external debt (in percent of exports + remitt & ... & $\ldots$ & 1.2 & & & 1.0 & 1.0 & 1.1 & 1.4 & 1.7 & 2.1 & & 2.2 & 1.7 & \\
\hline
\end{tabular}

1/ Includes both public and private sector external debt.

period debt ratio, with $r=$ nominal interest rate; $g=$ real GDP growth rate, and $\rho=$ growth rate of GDP deflator in US. dollar terms.

3/ Includes exceptional financing (i.e., changes in arrears and debt relief); changes in gross foreign assets; and valuation adjustments. For projections also includes contribution from price and exchange rate changes.

4/ Assumes that PV of private sector debt is equivalent to its face value.
5/ Current-year interest payments divided by previous period debt stock.

6/ Historical averages and standard deviations are generally derived over the past 10 years, subject to data availability.

8/ Grant-equivalent financing includes grants provided directly to the government and through new borrowing (difference between the face value and the PV of new debt) 
Table 2. Zambia: Public Sector Debt Sustainability Framework, Baseline Scenario, 2007-2030

(Percent of GDP, unless otherwise indicated)

\begin{tabular}{|c|c|c|c|c|c|c|c|c|c|c|c|c|c|c|c|}
\hline & \multicolumn{3}{|c|}{ Actual } & \multirow[b]{2}{*}{ Average 5/ } & \multirow[b]{2}{*}{$\begin{array}{c}\text { Standard } \\
\text { Deviation 5/ }\end{array}$} & \multicolumn{4}{|l|}{ Estimate } & \multicolumn{3}{|c|}{ Projections } & \multirow[b]{2}{*}{2020} & \multirow[b]{2}{*}{2030} & \multirow[b]{2}{*}{$\begin{array}{l}2016-30 \\
\text { Average } \\
\end{array}$} \\
\hline & 2007 & 2008 & 2009 & & & 2010 & 2011 & 2012 & 2013 & 2014 & 2015 & $\begin{array}{c}2010-15 \\
\text { Average } \\
\end{array}$ & & & \\
\hline Public sector debt 1/ & 25.8 & 26.5 & 26.2 & & & 25.5 & 26.3 & 27.6 & 28.3 & 27.3 & 25.5 & & 19.0 & 13.7 & \\
\hline of which foreign-currency denominated & 9.2 & 11.0 & 11.4 & & & 10.2 & 11.5 & 13.6 & 14.9 & 15.6 & 15.6 & & 13.6 & 8.8 & \\
\hline Change in public sector debt & -1.6 & 0.7 & -0.3 & & & -0.8 & 0.8 & 1.3 & 0.7 & -1.0 & -1.8 & & -0.9 & -0.4 & \\
\hline Identified debt-creating flows & -2.4 & -0.7 & -1.1 & & & -0.7 & 0.3 & 1.4 & 0.7 & -0.8 & -1.5 & & -0.9 & -0.4 & \\
\hline Primary deficit & -0.4 & 0.1 & 1.5 & 0.2 & 2.5 & 1.6 & 1.8 & 2.7 & 1.8 & 0.3 & -0.6 & 1.3 & -0.2 & -0.1 & -0.2 \\
\hline Revenue and grants & 23.0 & 22.3 & 20.0 & & & 20.6 & 20.2 & 20.9 & 20.9 & 21.5 & 21.9 & & 22.6 & 23.7 & \\
\hline of which: grants & 4.6 & 3.8 & 4.0 & & & 2.8 & 1.8 & 2.4 & 2.2 & 1.9 & 1.7 & & 1.2 & 0.7 & \\
\hline Primary (noninterest) expenditure & 22.6 & 22.4 & 21.5 & & & 22.2 & 22.0 & 23.5 & 22.7 & 21.7 & 21.3 & & 22.4 & 23.6 & \\
\hline Automatic debt dynamics & -1.9 & -0.8 & -2.6 & & & -2.3 & -1.5 & -1.3 & -1.1 & -1.1 & -0.9 & & -0.7 & -0.3 & \\
\hline Contribution from interest rate/growth differential & -1.9 & -2.0 & -1.3 & & & -1.3 & -1.3 & -1.2 & -1.2 & -1.1 & -1.0 & & -0.6 & -0.3 & \\
\hline of which: contribution from average real interest rate & -0.3 & -0.6 & 0.2 & & & 0.3 & 0.3 & 0.4 & 0.6 & 0.8 & 0.9 & & 0.6 & 0.5 & \\
\hline of which: contribution from real GDP growth & -1.6 & -1.4 & -1.6 & & & -1.6 & -1.5 & -1.7 & -1.8 & -1.9 & -1.9 & & -1.2 & -0.8 & \\
\hline Contribution from real exchange rate depreciation & -0.1 & 1.2 & -1.2 & & & -1.0 & -0.2 & -0.1 & 0.0 & 0.1 & 0.1 & & $\ldots$ & $\ldots$ & \\
\hline Other identified debt-creating flows & 0.0 & 0.0 & 0.0 & & & 0.0 & 0.0 & 0.0 & 0.0 & 0.0 & 0.0 & & 0.0 & 0.0 & \\
\hline Privatization receipts (negative) & 0.0 & 0.0 & 0.0 & & & 0.0 & 0.0 & 0.0 & 0.0 & 0.0 & 0.0 & & 0.0 & 0.0 & \\
\hline Recognition of implicit or contingent liabilities & 0.0 & 0.0 & 0.0 & & & 0.0 & 0.0 & 0.0 & 0.0 & 0.0 & 0.0 & & 0.0 & 0.0 & \\
\hline Debt relief (HIPC and other) & 0.0 & 0.0 & 0.0 & & & 0.0 & 0.0 & 0.0 & 0.0 & 0.0 & 0.0 & & 0.0 & 0.0 & \\
\hline Other (specify, e.g. bank recapitalization) & 0.0 & 0.0 & 0.0 & & & 0.0 & 0.0 & 0.0 & 0.0 & 0.0 & 0.0 & & 0.0 & 0.0 & \\
\hline Residual, including asset changes & 0.8 & 1.4 & 0.8 & & & -0.1 & 0.5 & 0.0 & -0.1 & -0.1 & -0.2 & & 0.0 & 0.0 & \\
\hline \multicolumn{16}{|l|}{ Other S ustainability Indicators } \\
\hline PV of public sector debt & 16.6 & 15.5 & 22.6 & & & 22.5 & 23.5 & 25.1 & 26.1 & 25.3 & 23.6 & & 17.3 & 12.7 & \\
\hline of which foreign-currency denominated & 0.0 & 0.0 & 7.8 & & & 7.3 & 8.8 & 11.1 & 12.7 & 13.6 & 13.7 & & 11.9 & 7.8 & \\
\hline of which external & ... & $\ldots$ & 7.8 & & & 7.3 & 8.8 & 11.1 & 12.7 & 13.6 & 13.7 & & 11.9 & 7.8 & \\
\hline PV of contingent liabilities (not included in public sector debt) & & $\ldots$ & $\ldots$ & & & $\ldots$ & $\ldots$ & & & $\ldots$ & & & & & \\
\hline Gross financing need $2 /$ & 6.4 & 7.2 & 10.6 & & & 10.7 & 10.8 & 11.6 & 10.4 & 8.6 & 7.0 & & 4.1 & 3.6 & \\
\hline $\mathrm{PV}$ of public sector debt-to-revenue and grants ratio (percent) & 72.2 & 69.3 & 113.1 & & & 109.5 & 116.5 & 120.2 & 125.1 & 117.6 & 107.7 & & 76.6 & 53.4 & \\
\hline $\mathrm{PV}$ of public sector debt-to-revenue ratio (percent) & 90.0 & 83.3 & 141.8 & & & 126.4 & 128.0 & 136.0 & 139.5 & 128.7 & 116.6 & & 81.0 & 55.0 & \\
\hline of which external $3 /$ & $\ldots$ & $\ldots$ & 48.8 & & & 40.8 & 47.7 & 60.1 & 68.1 & 69.2 & 67.7 & & 55.8 & 33.7 & \\
\hline Debt service-to-revenue and grants ratio (percent) 4 / & 9.3 & 13.3 & 16.3 & & & 15.7 & 14.4 & 13.6 & 13.5 & 13.0 & 12.7 & & 8.3 & 6.8 & \\
\hline Debt service-to-revenue ratio (percent) $4 /$ & 11.6 & 16.0 & 20.4 & & & 18.1 & 15.8 & 15.4 & 15.0 & 14.2 & 13.7 & & 8.8 & 7.0 & \\
\hline Primary deficit that stabilizes the debt-to-GDP ratio & 1.2 & -0.6 & 1.8 & & & 2.4 & 1.0 & 1.3 & 1.2 & 1.2 & 1.2 & & 0.7 & 0.3 & \\
\hline \multicolumn{16}{|l|}{ Key macroeconomic and fiscal assumptions } \\
\hline Real GDP growth (percent) & 6.2 & 5.7 & 6.3 & 5.3 & 1.0 & 6.6 & 6.4 & 6.7 & 6.8 & 7.3 & 7.4 & 6.9 & 6.5 & 6.0 & 6.3 \\
\hline Average nominal interest rate on forex debt (percent) & 0.7 & 1.8 & 0.9 & 1.3 & 0.6 & 1.8 & 0.9 & 0.1 & 1.0 & 2.2 & 2.3 & 1.4 & 2.8 & $2.5^{5}$ & 2.5 \\
\hline Average real interest rate on domestic debt (percent) & -0.5 & -3.5 & 1.9 & -3.1 & 2.7 & 1.5 & 2.2 & 4.4 & 5.4 & 5.9 & $7.4^{\circ}$ & 4.5 & 7.9 & $9.2^{\circ}$ & 8.4 \\
\hline Real exchange rate depreciation (percent, + indicates dep reciation) & -1.0 & 13.8 & -11.9 & -6.5 & 11.7 & -9.5 & $\ldots$ & $\ldots$ & $\ldots$ & $\ldots$ & $\ldots$ & $\ldots$ & $\ldots$ & $\ldots$ & $\ldots$ \\
\hline Inflation rate (GDP deflator, percent) & 10.9 & 12.8 & 10.4 & 18.0 & 6.1 & 10.3 & 7.6 & 5.5 & 4.6 & 4.6 & 4.5 & 6.2 & 5.0 & 5.0 & 5.0 \\
\hline Growth of real primary spending (deflated by GDP deflator, percent) & 0.1 & 0.0 & 0.0 & 0.0 & 0.2 & 0.1 & 0.1 & 0.1 & 0.0 & 0.0 & 0.1 & 0.1 & 0.1 & 0.1 & 0.1 \\
\hline Grant element of new external borrowing (percent) & $\ldots$ & $\ldots$ & $\ldots$ & $\ldots$ & $\ldots$ & 29.5 & 20.7 & 14.7 & 12.5 & 18.6 & 15.6 & 18.6 & 17.7 & 15.9 & $\ldots$ \\
\hline
\end{tabular}

Sources: Country authorities; and staff estimates and projections.

2/ Gross financing need is defined as the primary deficit plus debt service plus the stock of short-term debt at the end of the last period.

3/ Revenues excluding grants.

4/ Debt service is defined as the sum of interest and amortization of medium and long-term debt.

5/ Historical averages and standard deviations are generally derived over the past 10 years, subject to data availability. 
Table 3. Zambia: Sensitivity Analysis for Key Indicators of Public and Publicly Guaranteed External Debt, 2010-2030 (Percent)

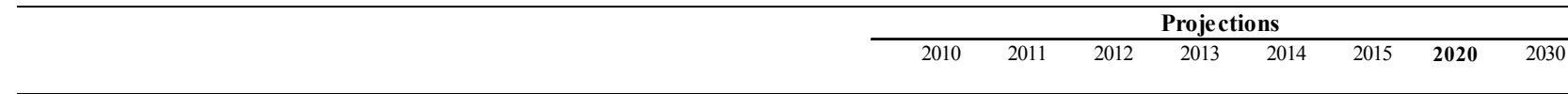

\section{PV of debt-to GDP ratio}

Baseline

\section{A. Alternative Scenarios}

A1. Key variables at their historical averages in 2010-2030 1/

A2. New public sector loans on less favorable terms in 2010-2030 2

\section{B. Bound Tests}

B1. Real GDP growth at historical average minus one standard deviation in 2011-2012 B2. Export value growth at historical average minus one standard deviation in 2011-2012 3 / B3. US dollar GDP deflator at historical average minus one standard deviation in 2011-2012 B4. Net non-debt creating flows at historical average minus one standard deviation in 2011-2012 4/ B5. Combination of B1-B4 using one-half standard deviation shocks

B6. One-time 30 percent nominal depreciation relative to the baseline in 20115

$\begin{array}{rrrrrrrr}7 & 9 & 11 & 13 & 14 & 14 & \mathbf{1 2} & 8 \\ & & & & & & & \\ 7 & 14 & 18 & 21 & 24 & 27 & \mathbf{3 7} & 36 \\ 7 & 9 & 12 & 14 & 15 & 15 & \mathbf{1 4} & 10 \\ & & & & & & & \\ & & & & & & & \\ 7 & 9 & 11 & 13 & 14 & 14 & \mathbf{1 1} & 6 \\ 7 & 10 & 14 & 15 & 16 & 15 & \mathbf{1 2} & 6 \\ 7 & 10 & 14 & 16 & 17 & 17 & \mathbf{1 4} & 8 \\ 7 & 9 & 13 & 14 & 15 & 15 & \mathbf{1 2} & 6 \\ 7 & 6 & 2 & 4 & 5 & 6 & \mathbf{6} & 6 \\ 7 & 12 & 15 & 17 & 18.1 & 18.0 & \mathbf{1 5} & 8\end{array}$

\section{PV of debt-to-exports ratio}

Baseline

\section{A. Alternative Scenarios}

A1. Key variables at their historical averages in 2010-2030 1/

A2. New public sector loans on less favorable terms in 2010-2030 2

\section{B. Bound Tests}

B1. Real GDP growth at historical average minus one standard deviation in 2011-2012

B2. Export value growth at historical average minus one standard deviation in 2011-2012 3

B3. US dollar GDP deflator at historical average minus one standard deviation in 2011-2012

B4. Net non-debt creating flows at historical average minus one standard deviation in 2011-2012 4/

B5. Combination of B1-B4 using one-half standard deviation shocks

B6. One-time 30 percent nominal depreciation relative to the baseline in 20115 /

$\begin{array}{rrrrrrrr}16 & 23 & 33 & 40 & 41 & 42 & \mathbf{3 5} & 23 \\ & & & & & & & \\ 16 & 36 & 55 & 68 & 74 & 84 & \mathbf{1 0 9} & 105 \\ 16 & 24 & 36 & 44 & 46 & 47 & \mathbf{4 0} & 28 \\ & & & & & & & \\ & & & & & & & \\ 16 & 23 & 33 & 39 & 40 & 41 & \mathbf{3 1} & 18 \\ 16 & 27 & 43 & 50 & 50 & 50 & \mathbf{3 8} & 19 \\ 16 & 23 & 33 & 39 & 40 & 41 & \mathbf{3 1} & 18 \\ 16 & 24 & 38 & 45 & 45 & 45 & \mathbf{3 4} & 18 \\ 16 & 13 & 4 & 9 & 12 & 13 & \mathbf{1 3} & 13 \\ 16 & 23 & 33 & 39 & 40 & 41 & \mathbf{3 1} & 18\end{array}$

\section{PV of debt-to-revenue ratio}

\section{Baseline}

\section{A. Alternative Scenarios}

A1. Key variables at their historical averages in 2010-2030 1/

A2. New public sector loans on less favorable terms in 2010-2030 2

\section{B. Bound Tests}

B1. Real GDP growth at historical average minus one standard deviation in 2011-2012 B2. Export value growth at historical average minus one standard deviation in 2011-2012 3 B3. US dollar GDP deflator at historical average minus one standard deviation in 2011-2012 B4. Net non-debt creating flows at historical average minus one standard deviation in 2011-2012 4/ B5. Combination of B1-B4 using one-half standard deviation shocks

B6. One-time 30 percent nominal depreciation relative to the baseline in $20115 /$
48

$\begin{array}{llrlllll}41 & 48 & 62 & 70 & 70 & 68 & \mathbf{5 2} & 27 \\ 41 & 54 & 74 & 80 & 79 & 76 & \mathbf{5 7} & 27 \\ 41 & 55 & 76 & 86 & 86 & 83 & \mathbf{6 5} & 34 \\ 41 & 50 & 69 & 76 & 75 & 72 & \mathbf{5 5} & 27 \\ 41 & 31 & 9 & 21 & 27 & 29 & \mathbf{2 9} & 27 \\ 41 & 64 & 81 & 92 & 92 & 89 & \mathbf{6 9} & 36\end{array}$


Table 3. Zambia: Sensitivity Analysis for Key Indicators of Public and Publicly Guaranteed External Debt, 2010-2030 (continued) (Percent)

Debt service-to-exports ratio

Baseline

A. Alternative Scenarios

A1. Key variables at their historical averages in 2010-2030 1/

A2. New public sector loans on less favorable terms in 2010-2030 2

\section{B. Bound Tests}

B1. Real GDP growth at historical average minus one standard deviation in 2011-2012

B2. Export value growth at historical average minus one standard deviation in 2011-2012 3/

B3. US dollar GDP deflator at historical average minus one standard deviation in 2011-2012

B4. Net non-debt creating flows at historical average minus one standard deviation in 2011-2012 4/

B5. Combination of B1-B4 using one-half standard deviation shocks

B6. One-time 30 percent nominal depreciation relative to the baseline in 20115 /

Debt service-to-revenue ratio

Baseline

\section{A. Alternative Scenarios}

A1. Key variables at their historical averages in 2010-2030 1/

A2. New public sector loans on less favorable terms in 2010-2030 2

B. Bound Tests

B1. Real GDP growth at historical average minus one standard deviation in 2011-2012

B2. Export value growth at historical average minus one standard deviation in 2011-2012 3/

B3. US dollar GDP deflator at historical average minus one standard deviation in 2011-2012

B4. Net non-debt creating flows at historical average minus one standard deviation in 2011-2012 4/

B5. Combination of B1-B4 using one-half standard deviation shocks

B6. One-time 30 percent nominal depreciation relative to the baseline in 2011 5/

Memorandum item:

Grant element assumed on residual financing (i.e., financing required above baseline) 6 /
3

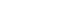

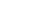

) 
Table 4. Zambia: Sensitivity Analysis for Key Indicators of Public Debt 2010-2030

\begin{tabular}{|c|c|c|c|c|c|c|c|c|}
\hline & \multicolumn{8}{|c|}{ Projections } \\
\hline & 2010 & 2011 & 2012 & 2013 & 2014 & 2015 & 2020 & 2030 \\
\hline \multicolumn{9}{|c|}{ PV of Debt-to-GDP Ratio } \\
\hline Baseline & 23 & 24 & 25 & 26 & 25 & 24 & 17 & 13 \\
\hline \multicolumn{9}{|l|}{ A. Alternative scenarios } \\
\hline A1. Real GDP growth and primary balance are at historical averages & 23 & 22 & 22 & 22 & 22 & 22 & 19 & 18 \\
\hline A2. Primary balance is unchanged from 2010 & 23 & 23 & 24 & 25 & 25 & 26 & 26 & 30 \\
\hline A3. Permanently lower GDP growth 1/ & 23 & 24 & 25 & 26 & 26 & 24 & 19 & 19 \\
\hline
\end{tabular}

\section{B. Bound tests}

B1. Real GDP growth is at historical average minus one standard deviations in 2011-2012

B2. Primary balance is at historical average minus one standard deviations in 2011-2012

B3. Combination of B1-B2 using one half standard deviation shocks

B4. One-time 30 percent real depreciation in 2011

B5. 10 percent of GDP increase in other debt-creating flows in 2011

PV of Debt-to-Revenue Ratio 2/
Bas eline

\section{A. Alternative scenarios}

A 1. Real GDP growth and primary balance are at historical averages

A2. Primary balance is unchanged from 2010

A3. Permanently lower GDP growth 1/

$\begin{array}{llllllll}23 & 24 & 27 & 29 & 29 & 28 & 24 & 24 \\ 23 & 24 & 26 & 27 & 26 & 24 & 18 & 13 \\ 23 & 24 & 25 & 26 & 26 & 25 & 21 & 21 \\ 23 & 26 & 28 & 29 & 28 & 26 & 20 & 16 \\ 23 & 32 & 33 & 34 & 33 & 31 & 23 & 16\end{array}$

109

116

$\begin{array}{llllllll}109 & 111 & 107 & 107 & 103 & 99 & 84 & 75\end{array}$

$\begin{array}{llllllll}109 & 116 & 116 & 120 & 118 & 117 & 116 & 129\end{array}$

$\begin{array}{llllllll}109 & 117 & 121 & 127 & 120 & 111 & 85 & 81\end{array}$

\section{B. Bound tests}

B1. Real GDP growth is at historical average minus one standard deviations in 2011-2012

B2. Primary balance is at historical average minus one standard deviations in 2011-2012

B3. Combination of B1-B2 using one half standard deviation shocks

B4. One-time 30 percent real depreciation in 2011

B5. 10 percent of GDP increase in other debt-creating flows in 2011

Debt Service-to-Revenue Ratio 2/

\section{Baseline}

$\begin{array}{rrrrrrrr}109 & 120 & 130 & 138 & 133 & 125 & 106 & 100 \\ 109 & 120 & 124 & 129 & 121 & 111 & 79 & 55 \\ 109 & 117 & 117 & 125 & 121 & 113 & 93 & 87 \\ 109 & 131 & 133 & 138 & 130 & 120 & 89 & 69 \\ 109 & 158 & 159 & 162 & 152 & 139 & 100 & 66\end{array}$

\section{A. Alternative scenarios}

A1. Real GDP growth and primary balance are at historical averages

A2. Primary balance is unchanged from 2010

A3. Permanently lower GDP growth $1 /$

$\begin{array}{rrrrrrrr}16 & 15 & 14 & 13 & 13 & 13 & 9 & 9 \\ 16 & 14 & 14 & 13 & 13 & 13 & 9 & 10 \\ 16 & 14 & 14 & 14 & 13 & 13 & 9 & 8\end{array}$

\section{B. Bound tests}

B1. Real GDP growth is at historical average minus one standard deviations in 2011-2012

B2. Primary balance is at historical average minus one standard deviations in 2011-2012

B3. Combination of B1-B2 using one half standard deviation shocks

B4. One-time 30 percent real depreciation in 2011

B5. 10 percent of GDP increase in other debt-creating flows in 2011

Sources: Country authorities; and staff es timates and projections.

1/ Assumes that real GDP growth is at baseline minus one standard deviation divided by the square root of the length of the projection period.

2/ Revenues are defined inclusive of grants. 


\section{ANNEX I. ZAMBIA: RELATIONS WITH THE FUND}

(As of October 31, 2010)

I. Membership Status: Joined: September 23, 1965; Article VIII

II. General Resources Account:

Quota

Fund holdings of currency

Reserve position in Fund

III. SDR Department:

Net cumulative allocation

Holdings
SDR Million

489.10

489.10

0.02

SDR Million

469.14

406.03

SDR Million

237.78
Percent

Quota

100.0

100.0

0.0

Percent Allocation

100.0

86.55

Percent Quota

ECF arrangements

V. Latest Financial Arrangements:

\begin{tabular}{lrrrr}
\hline Type & $\begin{array}{r}\text { Approval } \\
\text { Date }\end{array}$ & $\begin{array}{r}\text { Expiration } \\
\text { Date }\end{array}$ & $\begin{array}{r}\text { Amount Approved } \\
\text { (SDR Million) }\end{array}$ & $\begin{array}{r}\text { Amount Drawn } \\
\text { (SDR Million) }\end{array}$ \\
\hline ECF $^{22}$ & $06 / 04 / 2008$ & $06 / 03 / 2011$ & 220.10 & 183.31 \\
$\mathrm{ECF}^{1}$ & $06 / 16 / 2004$ & $09 / 30 / 2007$ & 220.10 & 220.10 \\
$\mathrm{ECF}^{1}$ & $03 / 25 / 1999$ & $03 / 28 / 2003$ & 278.90 & 237.52 \\
\hline
\end{tabular}

VI. Projected Payments to the Fund

(SDR million; based on existing use of resources and present holdings of SDRs)

\begin{tabular}{lrrrrr}
\hline & \multicolumn{5}{c}{ Forthcoming } \\
\cline { 2 - 5 } Principal & 2010 & 2011 & 2012 & 2013 & 2014 \\
\cline { 2 - 6 } Charges/interest & & 3.30 & 7.70 & 11.70 & 23.09 \\
Total & $\underline{0.05}$ & $\underline{0.26}$ & $\underline{0.83}$ & $\underline{0.81}$ & $\underline{0.78}$ \\
\hline
\end{tabular}

\footnotetext{
${ }^{22}$ Formerly PRGF.
} 


\section{Implementation of HIPC Initiative}

\section{Enhanced \\ Framework}

Commitment of HIPC assistance

Decision point date

Dec. 2000

Assistance committed (1999 NPV terms) ${ }^{23}$

By all creditors (US\$ million)

Of which: Fund assistance (US\$ million)

602.00

(SDR equivalent in millions)

468.80

Completion point date

April 2005

Disbursement of IMF assistance (SDR million)

Assistance disbursed to Zambia

468.80

Interim assistance

351.60

Completion point balance

117.20

Additional disbursements of interest income ${ }^{24}$

39.47

Total disbursements

508.27

\section{Implementation of MDRI Assistance}

I. Total debt relief (SDR million) $)^{25}$

402.59

Of which: MDRI

398.47

HIPC

4.12

II. Debt relief by facility (SDR million)

Delivery date
January 2006

GRA

PRGT

Total

$\mathrm{n} / \mathrm{a}$

402.59

402.59

\footnotetext{
${ }^{23}$ Net present value (NPV) terms at the decision point under the enhanced framework.

${ }^{24}$ Under the enhanced framework, an additional disbursement is made at the completion point corresponding to interest income earned on the amount committed at the decision point but not disbursed during the interim period.

${ }^{25}$ The Multilateral Debt Relief Initiative (MDRI) provides 100 percent debt relief to eligible member countries that are qualified for assistance. The debt relief covers all debt owed to the Fund as of end-2004 that is outstanding at the time the member qualifies for the relief.
} 


\section{Safeguards Assessment}

Safeguards assessments of the Bank of Zambia (BoZ) were completed in June 2004, January 2009, and October 2010. The 2009 assessment concluded that the bank had adequate safeguards in several areas, but confirmed the existence of certain vulnerabilities in the BoZ's legal framework and financial reporting. The 2010 update report concluded that the BoZ had made progress in implementing safeguards recommendations. Staff noted improvements in the internal audit and internal control mechanisms. Weak statutory independence remains a substantive safeguards concern.

\section{Exchange Rate Arrangement}

The currency of Zambia is the kwacha. The exchange rate arrangement is a "float," with the kwacha exchange rate determined in the interbank market. The buying rate of the BoZ is a simple average of the primary dealers' low bid rates, and the BoZ's selling rate is the simple average of the primary dealers' high offer rates. On April 19, 2002, Zambia accepted the obligations of Article VIII, Sections 2, 3, and 4 of the Articles of Agreement. However, the Fund urged the authorities to eliminate the exchange restriction shown by the accumulation of external payments arrears, which is subject to Fund approval under Article VIII, as soon as possible.

\section{Article IV Consultations}

Zambia is on the standard 24-month Article IV consultation cycle, subject to the provisions of the decision on consultation cycles approved on July 15, 2002. The Executive Board concluded the last Article IV consultation on December 14, 2009.

\section{FSAP Participation and ROSC}

Zambia has participated in the financial sector assessment program (FSAP); an FSAP mission from the Fund and the World Bank conducted a comprehensive external assessment of the financial system April 30-May 15, 2002, and July 15-26, 2002. A mission from the Fund and the World Bank conducted a follow up FSAP in November 2008.

The fiscal transparency module of a Report on Observance of Standards and Codes (ROSC) assessing compliance with the IMF's Code of Good Practices on Fiscal TransparencyDeclaration of Principles was issued to the Executive Board on October 31, 2001. A ROSC-data module was issued to the Executive Board on January 18, 2005. 
XIII. Technical Assistance (since 2003)

Resident advisors

Department Dates Position

FAD 2002-03 Advisor on public expenditure

management

Technical assistance missions

\begin{tabular}{|c|c|c|}
\hline Department & Dates & Purpose \\
\hline \multirow[t]{5}{*}{ MFD } & January and May 2003 & $\begin{array}{l}\text { Development of foreign exchange interbank } \\
\text { market, monetary operations, and reform of the } \\
\text { financial system }\end{array}$ \\
\hline & September 2003 & $\begin{array}{l}\text { Monetary operations, reform of the financial } \\
\text { system, government securities market, and } \\
\text { payments system }\end{array}$ \\
\hline & April-October 2004 & $\begin{array}{l}\text { Resolution of nonbank financial institutions } \\
\text { (three missions) }\end{array}$ \\
\hline & April-May 2005 & Liquidity management operations \\
\hline & March 2006 & $\begin{array}{l}\text { Liquidity management, monetary and exchange } \\
\text { rate policies }\end{array}$ \\
\hline \multirow[t]{6}{*}{ MCM } & March 2009 & Contingency planning and lender of last resort \\
\hline & September 2007 & $\begin{array}{l}\text { Institutional arrangements and operation of the } \\
\text { foreign exchange market. }\end{array}$ \\
\hline & September 2007 & Foreign exchange market \\
\hline & November 2007 & Risk-based supervision \\
\hline & July 2008 & Bank restructuring \\
\hline & July 2009 & Debt Management Strategy \\
\hline \multirow[t]{5}{*}{ STA } & June 2004 & Data ROSC \\
\hline & April-May 2005 & Monetary Statistics (GDDS) \\
\hline & May 2005 & Government Finance Statistics (GDDS) \\
\hline & February 2006 & Real Sector (GDDS) \\
\hline & July 2006 & Real Sector (GDDS) \\
\hline
\end{tabular}


April 2008

January 2009

April 2010

FAD

LEG
July-August 2005

November 2005

July 2006

August 2006

October 2006

June 2008

November 2008

January 2009

April 2009

November 2009

February 2010

June 2010

August 2010

September 2010

August 2004

February 2005

May 2005
Monetary and Financial Statistics

Consumer Price Index

Government Finance Statistics

Regulations for the Public Finance Act

Fiscal regime for copper mining

Revenue administration

Follow up on fiscal arrangements for the mining sector

Review of tax policy

Tax administration

Tax administration

Tax administration

Public Financial Management

Tax Administration

Tax administration

Public Financial Management

Tax Policy

Public Financial Management

Assistance on amending legislation on nonbank financial institutions

Strengthening the regulatory framework for nonbank financial institutions

\section{Resident Representative}

A Fund Resident Representative first took up the position in Lusaka in June 1990. Mr. Perry Perone has been the Resident Representative since December 2009. 
ANNeX II. ZAMbia: JoInt WorLd BANK-Fund Work Program, 2010-11

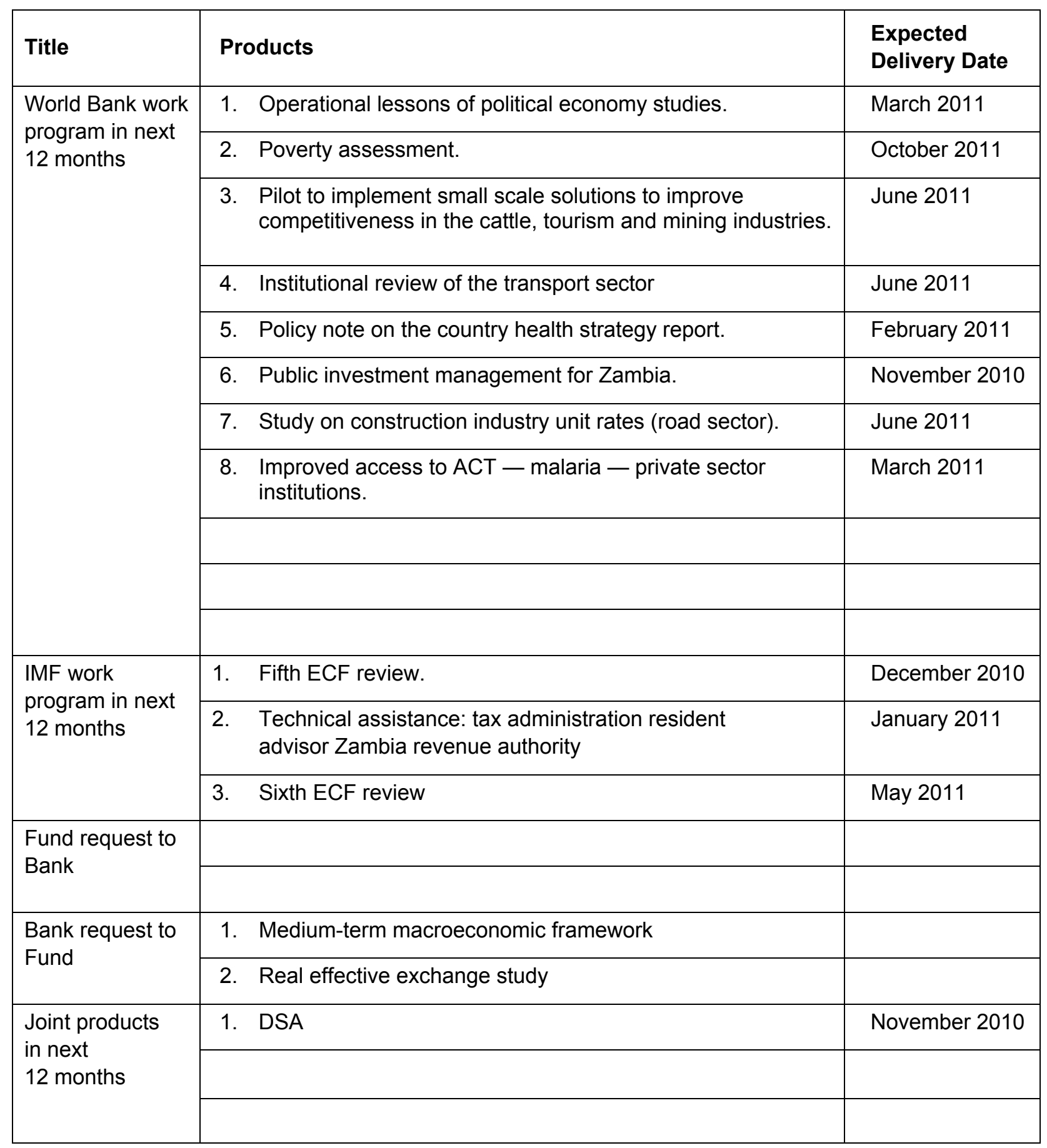




\section{ANNEX III. ZAMbia: STATISTICAL IsSUES}

As of November 9, 2010

\section{Assessment of Data Adequacy for Surveillance}

General: Data provision has some shortcomings, but is broadly adequate for surveillance. Issues with source data and compilation affect most datasets, but are particularly problematic in the national accounts, balance of payments, and consumer prices.

1. National accounts: There is a high degree of uncertainty attached to estimates of the level and growth rate of real GDP, because 1994 is the latest benchmark year for value-added ratios to estimate GDP under the production approach. For many important industry areas, such as wholesale and retail trade, construction, business services, and many other service industries, (consisting mainly of small-scale private service providers) no appropriate indicators exists. Data on total production and intermediate consumption of establishments are not available. On the expenditure side, no reliable indicators of household consumption exist and private final consumption expenditure is derived as a residual. Source data for estimating gross fixed capital formation and changes in stocks are incomplete. The situation largely reflects resource constraints and organizational weakness within the Central Statistical Office that have affected its ability to produce economic statistics on a timely basis.

Price statistics: The CPI broadly adheres to international methodological standards. The classification system used for compilation closely follows the Classification of Individual Consumption by Purpose. However, the measurement of inflation is also subject to a high degree of uncertainty because the weights for Zambia's CPI are derived from the Household Budget Survey (HBS) of 1993/94 and thus are out-of-date. STA is providing technical assistance in this area.

Government finance statistics: Data provision is broadly adequate for surveillance purposes. The transactional coverage of these data is however limited to government operations and transactions in nonfinancial assets. Data on transactions in financial assets and liabilities are still unavailable. The authorities report monthly budget data to AFR for operational use in a timely manner, but the data are often subject to substantial revisions, and data on extra-budgetary institutions and local governments are not available. STA is providing technical assistance in this area.

Monetary statistics: Data provision is broadly adequate for surveillance purposes. Since the 2005 monetary and financial statistics mission, there has been a noticeable improvement in the quality of monetary accounts compiled and reported in accordance with the standardized report forms (SRFs) for the BoZ and other depository corporations (ODCs). However, the implementation of some recommendations pertaining to the ODCs accounts still has some way to go, and in some instances the pace of implementation could have been accelerated. 
Balance of payments statistics: Little progress had been made since the assessment by the 2004 Data ROSC mission. Data sources remain poor (some items are estimated without reference to current source data) and compilation methods are inadequate. Resources available for balance of payments compilation have been increased, but are still inadequate, while coordination between the $\mathrm{BoZ}$ and $\mathrm{CSO}$ had improved. As a result, significant gaps in data remain in many areas including reinvested earnings, trade in services, and the financial account (including export proceeds held abroad by mining and nontraditional exporters). While the source data are generally adequate in terms of timeliness, they fall short in terms of coverage. As a result the shortcomings in source data coverage, indirect estimation methods are used, some of which have remained unchanged for many years and are out of date. Source data on private sector foreign assets and liabilities are insufficient to compile an International Investment Position statement.

External and domestic debt statistics: Data provision is broadly adequate for surveillance purposes. Recent efforts, facilitated by technical assistance, have led to an improvement in the consolidation of the debt databases, both in terms of external and domestic debt. Further work is underway in these areas.

\section{Data Standards and Quality}

Zambia has participated in the General Data Dissemination System (GDDS) since November 2002.

A Data ROSC Assessment was published in February 2005. 
Zambia: Table of Common Indicators Required for Surveillance

As of November 15, 2010

\begin{tabular}{|c|c|c|c|c|c|c|c|}
\hline & \multirow{2}{*}{$\begin{array}{l}\text { Date of Latest } \\
\text { Observation }\end{array}$} & \multirow{2}{*}{$\begin{array}{l}\text { Date } \\
\text { Received }\end{array}$} & \multirow{2}{*}{$\begin{array}{c}\text { Frequency } \\
\text { of } \\
\text { Data }^{7}\end{array}$} & \multirow{2}{*}{$\begin{array}{l}\text { Frequency } \\
\text { of } \\
\text { Reporting }^{7}\end{array}$} & \multirow{2}{*}{$\begin{array}{c}\text { Frequency } \\
\text { of } \\
\text { Publication } \\
7\end{array}$} & \multicolumn{2}{|c|}{ Memo Items: } \\
\hline & & & & & & $\begin{array}{l}\text { Data Quality - } \\
\text { Methodological } \\
\text { soundness }^{8}\end{array}$ & $\begin{array}{l}\text { Data Quality - Accuracy } \\
\text { and Reliability }\end{array}$ \\
\hline Exchange rates & Nov. 15, 2010 & Nov. 15, 2010 & $\mathrm{D}$ & $\mathrm{D}$ & $\mathrm{D}$ & & \\
\hline $\begin{array}{l}\text { International reserve assets and reserve liabilities of } \\
\text { the monetary authorities }\end{array}$ & Oct. 21,2010 & Oct. 27,2010 & W & W & M & & \\
\hline Reserve/base money & Oct. 21,2010 & Oct. 27,2010 & W & W & $\mathrm{F}$ & \multirow{4}{*}{ LO, LO, LO, LO } & \multirow{4}{*}{ LO, O, O, O, O } \\
\hline Broad money & Sept. 2010 & Oct. 27,2010 & M & M & M & & \\
\hline Central bank balance sheet & Sept. 2010 & Oct. 27,2010 & M & M & M & & \\
\hline Consolidated balance sheet of the banking system & Sept. 2010 & Oct. 27,2010 & M & M & M & & \\
\hline Interest rates ${ }^{2}$ & Nov. 11, 2010 & Nov. 15, 2010 & W & W & $\mathrm{F}$ & & \\
\hline Consumer Price Index & Oct. 2010 & Oct 28, 2010 & M & M & M & O, LO, O, LO & LNO, LO, LO, LNO, LO \\
\hline $\begin{array}{l}\text { Revenue, expenditure, balance and composition of } \\
\text { financing }^{3} \text { - general government }{ }^{4}\end{array}$ & NA & & & & & \multirow[t]{2}{*}{ LO, LNO, LNO, LO } & \multirow[t]{2}{*}{ LNO, LO, O, O, LNO } \\
\hline $\begin{array}{l}\text { Revenue, expenditure, balance and composition of } \\
\text { financing }{ }^{3} \text { - central government }\end{array}$ & Sept. 2010 & Oct. 29,2010 & M & M & M & & \\
\hline $\begin{array}{l}\text { Stocks of central government and central government- } \\
\text { guaranteed debt } t^{5}\end{array}$ & Q4, 2009 & Oct. 17,2010 & M & M & $A$ & & \\
\hline External current account balance & Q3, 2010 & Oct. 17,2010 & Q & Q & A & \multirow[t]{2}{*}{ LO, LNO, LNO, O } & \multirow[t]{2}{*}{ LNO, O, LNO, LO, LNO } \\
\hline Exports and imports of goods and services & Q3, 2010 & Oct. 17,2010 & Q & Q & A & & \\
\hline GDP/GNP & 2009 & Feb. 17, 2010 & A & A & A & LO, LO, LO, LO & LNO, LO, LNO, LNO, LNO \\
\hline Gross external debt & Q2, 2010 & Oct. 20,2010 & I & 1 & 1 & & \\
\hline International investment position ${ }^{6}$ & NA & NA & & & & & \\
\hline
\end{tabular}

${ }^{1}$ Includes reserve assets pledged or otherwise encumbered as well as net derivative positions.

${ }^{2}$ Both market-based and officially determined, including discounts rates, money market rates, rates on treasury bills, notes and bonds.

${ }^{3}$ Foreign, domestic bank, and domestic nonbank financing.

${ }^{4}$ The general government consists of the central government (budgetary funds, extra budgetary funds, and social security funds) and state and local governments.

Including currency and maturity composition.

${ }^{6}$ Includes external gross financial asset and liability positions vis-à-vis nonresidents.

${ }^{7}$ Daily (D), weekly (W), monthly (M), quarterly (Q), annually (A); irregular (I); or not available (NA).

${ }^{8}$ Reflects the assessment provided in the data ROSC, published February 1, 2005, and based on the findings of the mission that took place during May 18-June 3, 2004 for the dataset corresponding to the variable in each row. The assessment indicates whether international standards concerning (respectively) concepts and definitions, scope, classification/sectorization, and basis for recording are fully observed (O), largely observed (LO), largely not observed (LNO), or not observed (NO).

${ }^{9}$ Same as footnote 8, except referring to international standards concerning (respectively) source data, assessment of source data, statistical techniques, assessment and validation of intermediate

data and statistical outputs, and revision studies. 


\section{INTERNATIONAL MONETARY FUND \\ EXTERNAL RELATIONS DEPARTMENT}

Press Release No. 10/484

International Monetary Fund

FOR IMMEDIATE RELEASE

Washington, D.C. 20431 USA

December 10, 2010

\section{IMF Executive Board Completes Fifth Review Under ECF Arrangement with Zambia and Approves US\$28.3 Million Disbursement}

The Executive Board of the International Monetary Fund (IMF) today completed the fifth review of Zambia's economic performance under a program supported by the Extended Credit Facility (ECF). Completion of the review enables the immediate disbursement of an amount equivalent to SDR 18.395 million (about US\$28.3 million), bringing total disbursements under the arrangement to SDR 201.7 million (about US\$310.3 million).

In completing the review, the Executive Board also granted a waiver for the nonobservance of a performance criterion on non-concessional external debt at end-December 2009 and approved the modification of the performance criteria for end December 2010 on net domestic assets of the Bank of Zambia and on net domestic financing of the central government, as well as a modification to the performance criterion on non-concessional external debt. The ECF arrangement for Zambia was originally approved in June 2008 (see Press Release No 08/134), and then augmented in May 2009 by SDR 171.185 million (about US\$256.4 million) to an amount equivalent to SDR 220.095 million (about US\$329.7 million) (see Press Release No. 09/147). Zambia has been a member of the Fund since September 1965.

Following the Executive Board's discussion of Zambia, Mr. Naoyuki Shinohara, Deputy Managing Director and Acting Chair, made the following statement:

“Zambia's economic prospects continue to improve, thanks to sound macroeconomic policies and progress in structural reforms. Growth remains strong, inflation is subdued, and the external position has been solid. The main medium-term challenge is to create fiscal space for priority spending, enhance economic diversification and reduce poverty.

"A prudent policy stance will help shelter the economy from continued global uncertainty and ensure that underlying inflation, especially on nonfood items, continues to decline as targeted. The fiscal strategy remains centered on increasing revenues, including from the mining sector, containing wages and other recurrent spending, and improving the efficiency of spending. The 2011 budget is consistent with making significant progress in meeting these challenges. 
"Financial sector conditions are gradually improving, with credit to the private sector slowly reviving, although nonperforming loans remain high. While most banks are well capitalized and have ample liquidity, the authorities need to strengthen bank monitoring and contingency planning, to contain vulnerabilities.

"Financing needs are becoming more acute with regard to addressing growth-critical infrastructural requirements. Increased but prudent reliance on non-concessional financing is appropriate given the challenges in identifying additional concessional resources and the moderate external debt levels. However, non-concessional financing should remain strictly directed to growth-critical spending that would provide high economic returns. The strengthening of debt management and project appraisal capacity are critical in this regard and the authorities' determination to make progress in these areas expeditiously is welcome," added Mr. Shinohara. 


\section{Statement by Mr. Moeketsi Majoro, Executive Director for Zambia \\ December 10, 2010}

\section{Introduction}

My Zambian authorities wish to convey their gratitude to the Fund for the helpful policy dialogue and technical assistance in support of the country's macroeconomic program. Their program is guided by vision 2030, which is being implemented through the Fifth National Development Plan 2006-10 and the Sixth National Development Plan 2011-15 whose objectives are to sustain high positive growth and maintain macroeconomic stability in the near and medium term. This is in addition to accelerating the diversification program, enhancing competitiveness, pursuing infrastructure and human development as well as achieving the Millennium Development Goals (MDGs). The authorities seek completion of the fifth review under the ECF arrangement and financing assurances review. Moreover, they seek waiver of the missed end-2009 ceiling on non-concessional borrowing, and modification of end-December 2010 performance criteria. My authorities are in broad agreement with the staff report.

\section{Macroeconomic developments}

Economic growth for 2010 is expected to be higher than earlier projected at more than 6.6 percent as a result of continued strong performance in the agriculture, mining, tourism and construction sectors as well as supportive macroeconomic policies. Growth is expected to remain strong in the medium term, propelled by the mining and manufacturing sectors as agricultural output returns to trend levels. The fiscal deficit increased by 0.8 percent from an initial projection of 2.5 percent of GDP in 2010 arising from invalidation of the assumption on which the revised program target was based - the salary increase for 2010 was budgeted at 9 percent but the actual outturn after negotiations with the unions was 15 percent. Recruitment of teachers, medical staff and police; financing of surplus maize; and the fuel subsidy also contributed to the budget deficit. Inflation remained under control in the single digits and further declined from 7.3 percent in October to 7.1 percent in November 2010. Monetary policy implementation has been in line with the program and the balance of payments position continues to improve. The key challenges include enhancing revenue performance in the medium term, reducing high rural poverty, and financing infrastructure.

\section{Program performance}

Program performance was on track with all quantitative performance criteria for end-June 2010 being met. One indicative target on payment of domestic arrears was missed on account of pre-requisite investigation and verification process of the arrears by the Drug Enforcement Commission. The electricity tariffs benchmark was met with some delay of less than 4 weeks 
while the establishment of a lender of last resort framework was partly met, both of which were due to consultation processes that took longer.

On the case of misreporting, my authorities regret reporting to Fund staff a tentative interest rate of 1.25 percent on the OPEC Fund loan contracted on June 12, 2009 during the fourth review as contained in the MEFP and staff report. The loan in question financed the implementation of the second phase of the Cancer Diseases Hospital Project at the cost of US\$6.0 million with an interest rate of 1.5 percent and a grant element of 34 percent. The first phase of the project was financed by a loan from the same source of US\$5.6 million contracted in 2002 with an interest rate of 1 percent and a grant element of 36 percent. While the first loan clearly met the concessionality threshold of 35 percent, the second loan did not, missing the grant element by 1 percent. In view of the inadvertent nature of the misreporting and the corrective actions being undertaken by the authorities, including initiating disciplinary action and providing information to staff through one focal officer after clearance with the Senior Management, my authorities request granting a waiver for nonobservance of the non-concessional debt ceiling under de minimis procedures.

\section{Fiscal policy}

The authorities are committed to enhancing revenue performance and reducing the proportion of the wage bill in the medium-term in order to provide more room for capital spending and increased expenditure in social sectors. Revenue enhancement measures focus on broadening the tax base and increasing compliance, including for the mining sector. In this regard, the government will enforce compliance with the mining tax regime. On the expenditure side, recruitment freeze outside education, health and security sectors has been imposed for one year. The Food Reserve Agency (FRA) will recover part of the funds for financing the surplus maize through selling the bulk of the surplus maize to deficit countries in the region to moderate the cost on the budget.

\section{Monetary policy}

The monetary policy objective is to maintain single digits inflation and financial stability. The current framework based on monetary aggregates will remain in place during the migration to the interest rates framework to anchor inflation expectations in order to ensure smooth migration. As my authorities have indicated, they seek to benefit from Fund TA to ensure the adoption of international best practices.

\section{Debt management}

The authorities underscore their commitment to enhancing their debt management capacity. In this regard, debt management operations are being restructured through implementation of recommendations of the institutional development plan for the debt management office. The key recommendation is reorganizing and consolidating the office along functional lines. The authorities would further seek IMF TA in risk management and debt sustainability analysis. 


\section{Structural reforms}

The authorities are improving the management and overall performance of public service through the introduction of service delivery charters, customer service centers and development of a comprehensive public service pay policy. A salaries and wages review commission has been constituted to develop a comprehensive public services salaries structure. An anti-corruption implementation plan has been put in place to enhance the fight against corruption. The anti-corruption Act will be amended to align it with the policy and related legislation. The public interest disclosure bill and forfeiture of proceeds of crime bill has been passed by parliament. My authorities are ready for review by the Africa Peer Review Mechanism of the African Union, which aims at enhancing the standards of good governance.

A new public procurement Act establishing the Zambia Public Procurement Authority has been enacted to provide a solid framework for public procurement reforms, and audit committees have been appointed in Ministries to enhance the effectiveness and efficiency of use of public resources. My authorities continue to reduce the cost of doing business by implementing the private sector development reform program (PSDRP), which has made significant progress. The authorities have launched a simplified trade regime for micro, small and medium enterprises aimed at expanding capacity to exploit trade opportunities, the first one being with Malawi. Further, establishment of one-stop-border post is progressing well aimed at making cross border trade easier.

\section{Poverty reduction}

In their continued efforts to reduce the high poverty levels, especially in rural areas, and improve food security, my authorities expanded the farmer input support program, which contributed to the unprecedented harvest of 2.8 million metric tons of maize. My authorities should be congratulated for having achieved this outcome, which not only achieves food self-sufficiency, but also holds promise of export to other countries that still face food deficits. This outcome was new and the maize market was not adequately prepared to handle it. My authorities promptly responded by providing additional financial support to the FRA to purchase the crop from remote areas not usually reached by private players thereby helping correct the market failure that heightened as a result of the bumper harvest.

Agriculture marketing in Zambia remains fragile and need government support from time to time. One of the institutions that the government uses is the FRA for the purpose of managing strategic reverse and, thereby also playing a stabilizing role. To help address the challenges in agriculture marketing, the FRA will be trading on the Zambia Commodity Exchange to off load stocks in the market during periods of scarcity.

Further efforts to reduce poverty include enactment of an agriculture credit bill aimed at improving access to credit by farmers, and investing in irrigation and feeder roads. A credit guarantee scheme has also been established to improve access to finance by small businesses. 
A multi-year financial and technical assistance cash transfer scheme in the amount of US\$63 million over a 10 year period has been developed with the cooperation of donors aimed at reducing extreme poverty.

\section{Infrastructure financing}

One of the key objectives of the country's economic program is infrastructure development, which is critical in reducing the cost of doing business thereby facilitating private sector investment and trade. Implementation of infrastructure development has become difficult due to project specific ceilings on medium- to long-term non-concessional borrowing because it is limiting the ability of the government to implement the ongoing Road Sector Investment Program. The authorities do not expect the Board of the Fund nor Cooperating partners to decide which projects should be implemented. Therefore, my authorities request the Board to accordingly modify the end-December 2010 performance criteria.

\section{Conclusion}

The Zambian authorities consider their engagement with the Fund important in helping to support the implementation of their macroeconomic program. They are committed to enhancing conducive environment for private sector investment, while sustaining macroeconomic stability, public sector efficiency and accountability, creating the necessary fiscal space for capital spending, and ensuring debt sustainability. They request completion of the fifth review under the ECF arrangement and financing assurances review. In addition, they request waiver of the missed end-2009 ceiling on non-concessional borrowing, and modification of end-December 2010 performance criteria. 